Fizar Ahmed

Matching future job requirements with educational portfolio 
DEPARTMENT OF INFORMATION SYSTEMS

Supervisor: Ildikó Borbásné Szabó Ph.D.

(C) Fizar Ahmed 
CORVINUS UNIVERSITY OF BUDAPEST

DOCTORAL SCHOOL OF BUSINESS INFORMATICS

\section{Matching future job requirements with educational portfolio}

Doctoral dissertation

Fizar Ahmed

Budapest, 2018 



\section{CONTENT}

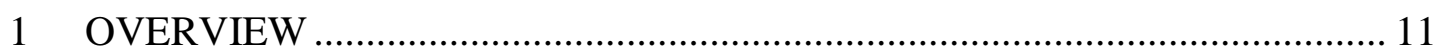

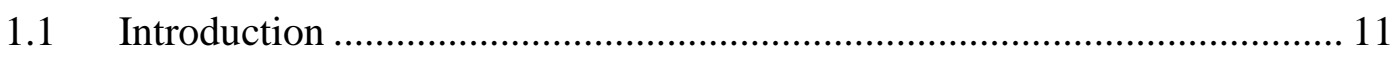

$1.2 \quad$ Higher education and job management ...................................................... 13

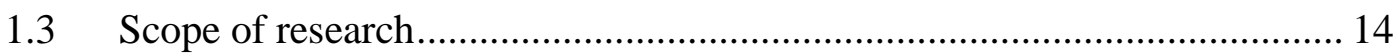

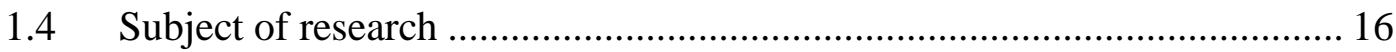

$1.5 \quad$ Research questions ................................................................................ 17

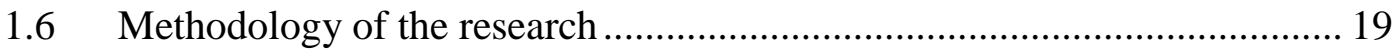

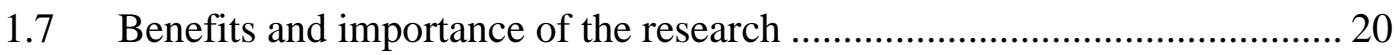

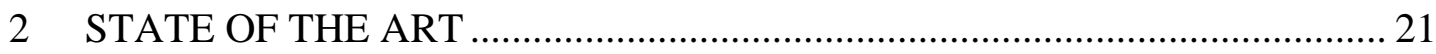

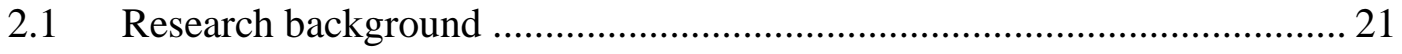

$2.2 \quad$ Beyond the state of the art ................................................................... 23

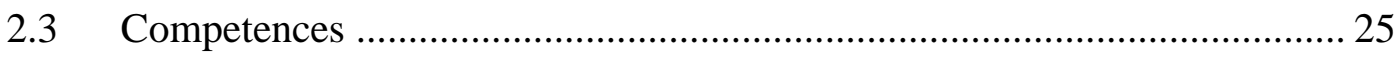

$2.4 \quad$ Stakeholders /interested parties ............................................................. 26

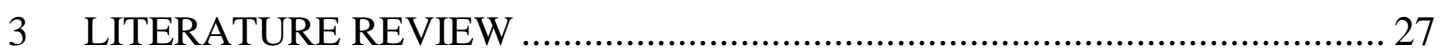

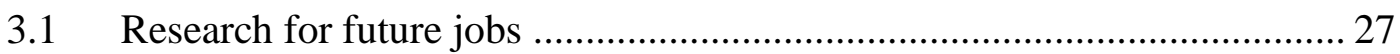

3.2 Economic models for future jobs …………………………………….... 28

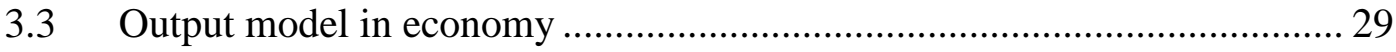

3.4 Educational portfolio for future jobs ............................................................ 32

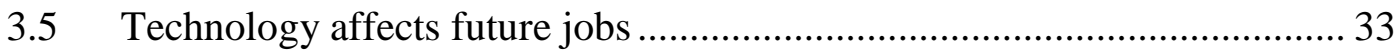

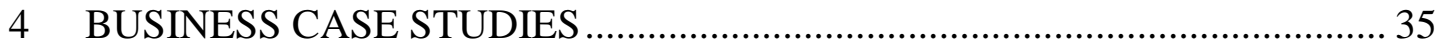

4.1 Reasons why labour markets are in disequilibrium...................................... 38

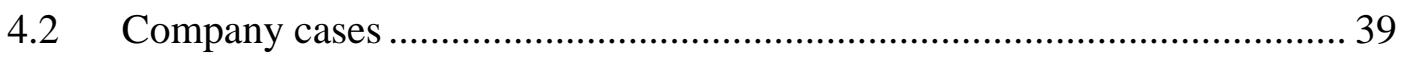

4.2.1 Faurecia: Sweden to the Czech Republic............................................... 39

4.2.2 IBM Germany to Poland ........................................................................ 40

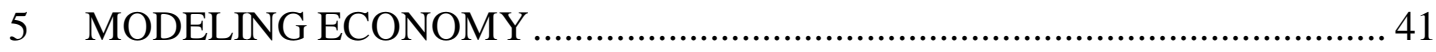

$5.1 \quad$ Input-Output (I/O) concept and its origins ................................................ 41 
5.2 Application of Input-Output Approach …............................................ 41

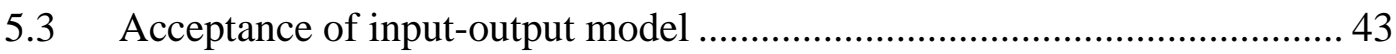

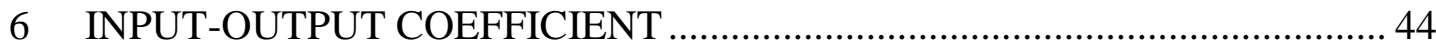

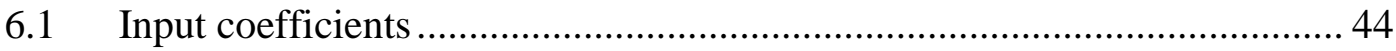

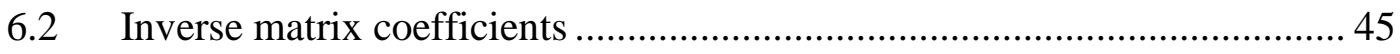

6.3 Labour input-output analysis coefficients ............................................ 46

7 BASIC ASSUMPTIONS OF INPUT-OUTPUT ANALYSIS .......................... 47

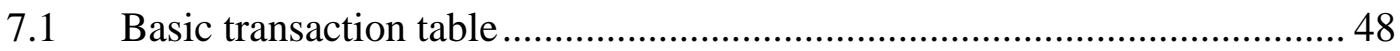

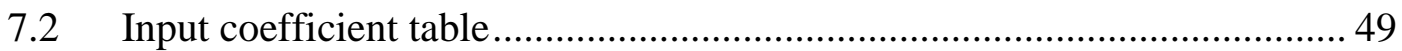

7.3 Inverse matrix coefficients (handling of imports) ....................................51

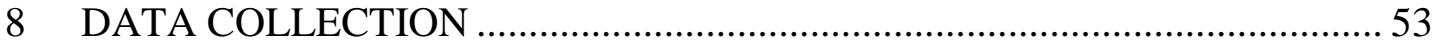

8.1 Data sources - Open Data / Open Government Data / GOD ....................... 53

8.1.1 Central Statistical Office (CSO), Hungary …...................................... 53

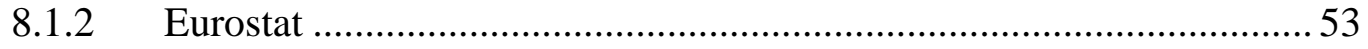

8.1.3 OECD

8.1.4 World Input-Output Database (WIOD) ...........................................5

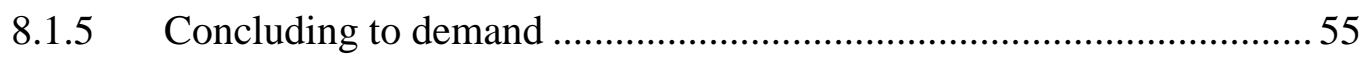

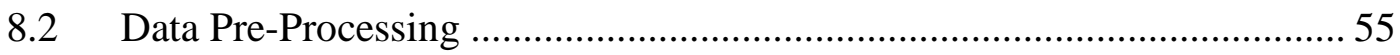

8.2.1 Input-Output (IO) Table Data in Excel Format...................................55

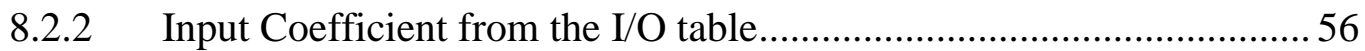

8.2.3 Import coefficient from the IO table ............................................. 57

8.2.4 Labour coefficient from the Hungarian Statistical Data ......................5 57

8.2.5 Occupation coefficient from the ISCO dataset ................................5 57

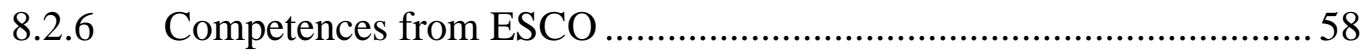

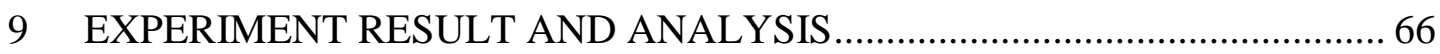

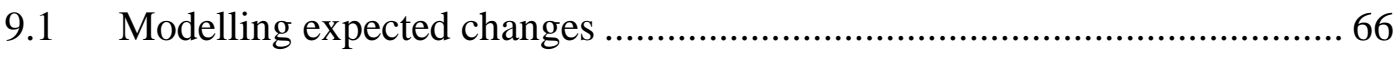

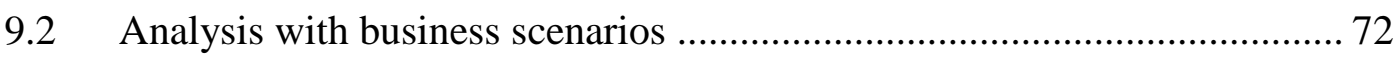


9.3 Time horizon / preference selection 72

9.3.1 The growing economy (Foreign Direct Investment)......................... 72

9.3.2 Changing the requested labour force (productivity, unchanged structure)

9.3.3 Changing the requested labour force (technology, different structure) 74

9.3.4 Other internal and external factors ................................................. 76

9.4 ReSUlT of selected business scenario: E-car manufacturing .................... 79

9.5 Changes in the importance of managerial competences........................... 85

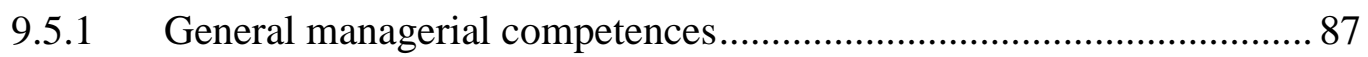

9.5.2 General competences before and after changes in coefficients .......... 92

9.5.3 Sector-specific managerial competences ........................................ 93

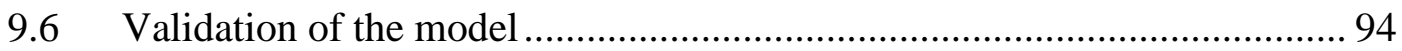

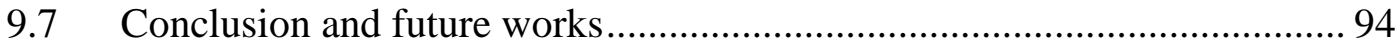

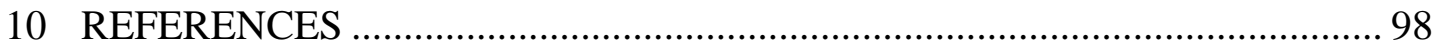

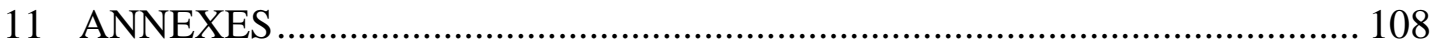

11.1 Table-1 Supply and Use Table ......................................................... 108

11.2 Table-2 Input Coefficient Table …....................................................... 110

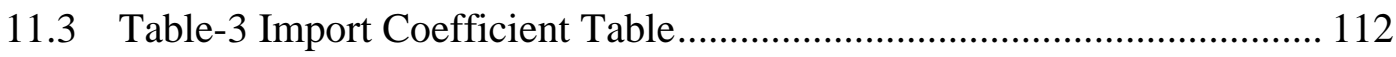

11.4 Table-4 Labour Coefficient Table …..................................................... 114

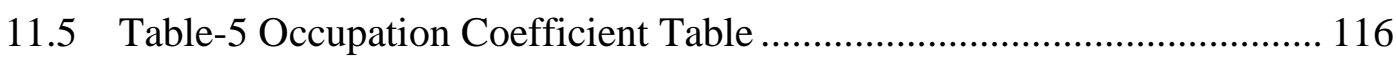

11.6 Table - 6 Sector wise Competence Chart for manager............................ 118

11.7 General Competence Chart for manager ............................................... 126

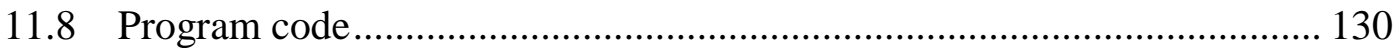




\section{FIGURES}

Figure 1 the relation between HEI and World of Labour ....................................... 14

Figure 2 Unemployment rate in Hungary, Source: CSO …...................................... 16

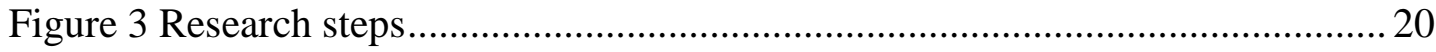

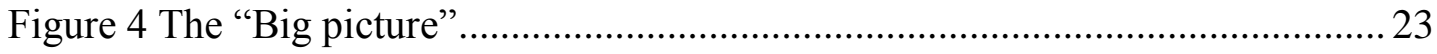

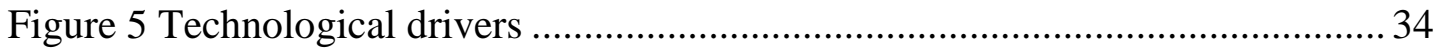

Figure 6 Drivers of change (Source: Future of Jobs Survey, World Economic Forum, 2016)

Figure 7 Illustration of a labour shortage (Source: Barnow, Trutko \& Piatak, 2013).

Figure 8 ESCO framework (Source- http://euhap.eu) .............................................. 58

Figure 9 Common terminology provided by ESCO ….......................................... 62

Figure 10 Shows the number of workforces on production (thousand Euros) of the products broken down by the sections of the industries classification the NACE Rev.

2 , in thousand persons.

Figure 11 Changes in labour output 69

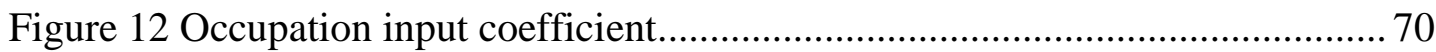

Figure 13 Sector-wise number of labour for manager .............................................. 70

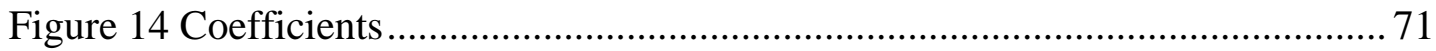

Figure 15 Thousand number of position change as follows the coefficient value..... 71

Figure 16 Number and distribution of managerial position by sectors .74 
Figure 17 Number and distribution of managerial position by sectors in 5 years ..... 75

Figure 18 Changing coefficient values between two industries.............................. 83

Figure 19 Total domestic product after changing coefficient. ................................. 83

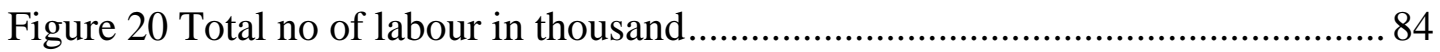

Figure 21 Occupation based labour like no of manager in a particular industry ....... 84

Figure 22 Plot shows labour changes after changing coefficient............................ 84

Figure 23 The distribution of general competences among the selected occupations 86

Figure 24 The graph of changes labour according to general competences 89

Figure 25 Difference between new situations 92

Figure 26 the distribution of sector-specific competences among the selected occupations. .93 


\section{TABLES}

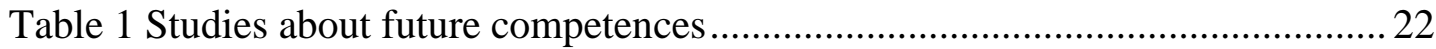

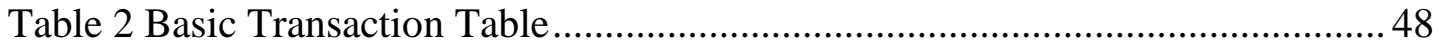

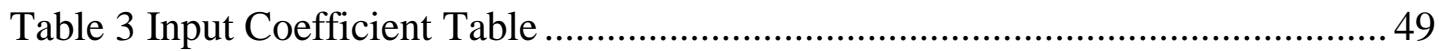

Table 4 Inverse Matrix Coefficient Handling of Imports ........................................51

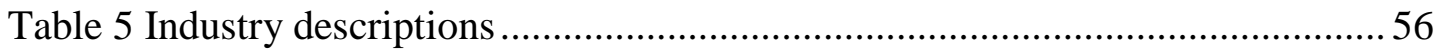

Table 6 Occupation coefficient Table. See Annex................................................. 57

Table 7 Occupation coefficient changes in percentages .........................................6 68

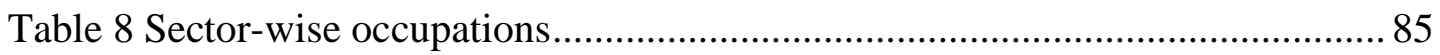

Table 9 General competence list with total labour both before and after changing

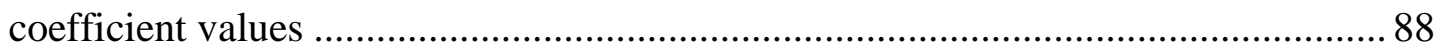

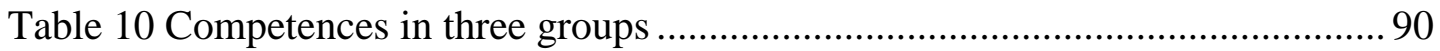




\section{OVERVIEW}

\subsection{Introduction}

Labour market is changing continually because of various environmental factors. Major influencing factors like expanding promising economies, an increasingly global labour market and new technology are all having a significant impact on the demand and required supply of skilled labours as well as prospect for new employment area. Therefore, uncovering the future job trends based on several economic indicator with the required skills in the industrial sector particularly in European industries are utmost important, this is in the main focus of this research.

Along with the other factors, economic growth of a country is affected by job creation. Creating jobs and income opportunities are vital for development. At present, most of the European countries are struggling with the problem of unequal employment situation, characterized by unemployment and manpower shortage at the same time. Consequently, creating new jobs, together with improving working conditions and the level of income from existing jobs are extremely important. To this end, the development of global trade and foreign direct investment can smooth the progress of this process. In addition, innovations and technologies contribute to economic growth and employment, where it is important to incorporate technologies to improve environmental protection.

In the coming years, changes of industrial production process impact profoundly on the generation of employment opportunities. Many of the major drivers of transformation currently affecting global industries are expected to have a major impact on jobs, ranging from significant job creation to job displacement, and from labour productivity to widening skills gaps. The present scenario in the industrial sectors was not available in many industries and countries just about ten years ago. The pace of such changes is accelerating continuously. It is expected that students entering universities today will ultimately end up working in completely new job types that do not yet exist. In such a rapidly growing employment landscape, the ability to anticipate and organize for future skills needs, job content and the 
aggregate impact on employment is ever more critical for businesses, governments and individuals in order to fully grab the opportunities presented by these trends to diminish undesirable outcomes.

To get a clear view of the situation we need to model the economy in its full complexity. There are many options for modelling. For the sake of this research Input-Output model proved to be suitable to take many dimensions into consideration. Input-Output Tables describe the sale and purchase relationships between producers and consumers within an economy. They can either show flows of finished or intermediate goods and services as defined in industry outputs (industry $\times$ industry) tables or according to product outputs (product $\times$ product) tables. These tables are made on the basis of input-output analysis that allows us to study the structural changes in an economy. It provides the tools necessary to assess industries, including their relationships to the other branches of the economy and the effects of final requirement for production on those relationships. Application of the input-output method in empirical study requires the availability and accessibility of basic statistical information. The most important economic applications, as dissimilar from engineering and business-management applications, have been made in such fields as economic demand, output, employment, and investment for the individual sectors of entire countries and of smaller economic regions. In addition, study of technological change and its effect on yield; analysis of the effect of remuneration, turnover, and tax changes on prices; and study of international and interregional economic relationships, consumption of natural resources, and developmental planning also made use of input-output tables.

In the present study, the primary focus is to find the future job requirement trends based on the input-output table data with the utilization of several valuable components of the table. EUROSTAT table data have been used to calculate the result. The data in input-output tables are available in EUROSTAT database for the reference years up to 2011 based on ESA 1995 and grouped by NACE Rev. 2. By the end of December 2014, national supply and use tables transmitted according to the ESA 2010 methodology. Supply, use and input-output tables provide detailed information for a given year on production activities, the supply and demand of goods and services, intermediate consumption, primary inputs and foreign trade. For 
economic analysis, country-based regional input-output tables are used here. For the employment data in different sectors, Hungarian statistical data are used for the same year. It can be used for further analysis in different countries in long-term context. Competences are used to model job requirements. The newest version of ESCO (European Skills, Competences, Qualifications and Occupations) were released a few month ago, hence this multilingual classification of competences and occupations serves as a basis for analysing future competence needs. These future competences can be matched with actual learning outcomes derived from an educational portfolio with using a system mentioned in (Borbásné Szabó, 2014) and its improved version applied in SMART (2012-1-ES1-LEO05-49395) and SMART-PLUS (2016-1-ES01KA202-025304) projects.

\subsection{Higher education and job management}

Job seekers can be classified in different groups. For instance, graduates from different Higher Education Institutions (HEIs), mobility worker, skilled unemployed who are searching for another job etc. HEIs are responsible for graduates only who passed immediately from there. These graduates have to be competent for different job types. Industry based competence is most important of them. There are lots of variation of competences in first, second or third economy, also have the variations in production, services and civil works.

For dramatic changes of technologies and other nature of jobs, stability time of competences need to be maintained by HEI. 3-5 years' time long is important for HEI to maintain the competence graphs. To minimize the gap in technology and other relevant issues between Member States of the European Union, they launched

the Strategies for Smart Specialisation Platform (S3 Platform) ${ }^{1}$ in June 2011 to provide professional advice to EU member states and regions for the design of their research and innovation strategies for smart specialisation. In this research, many

\footnotetext{
${ }^{1}$ http://s3platform.jrc.ec.europa.eu/
} 
economicalerimeters of EU Member States can be used for suggesting competence building as follows the present needs of industries.

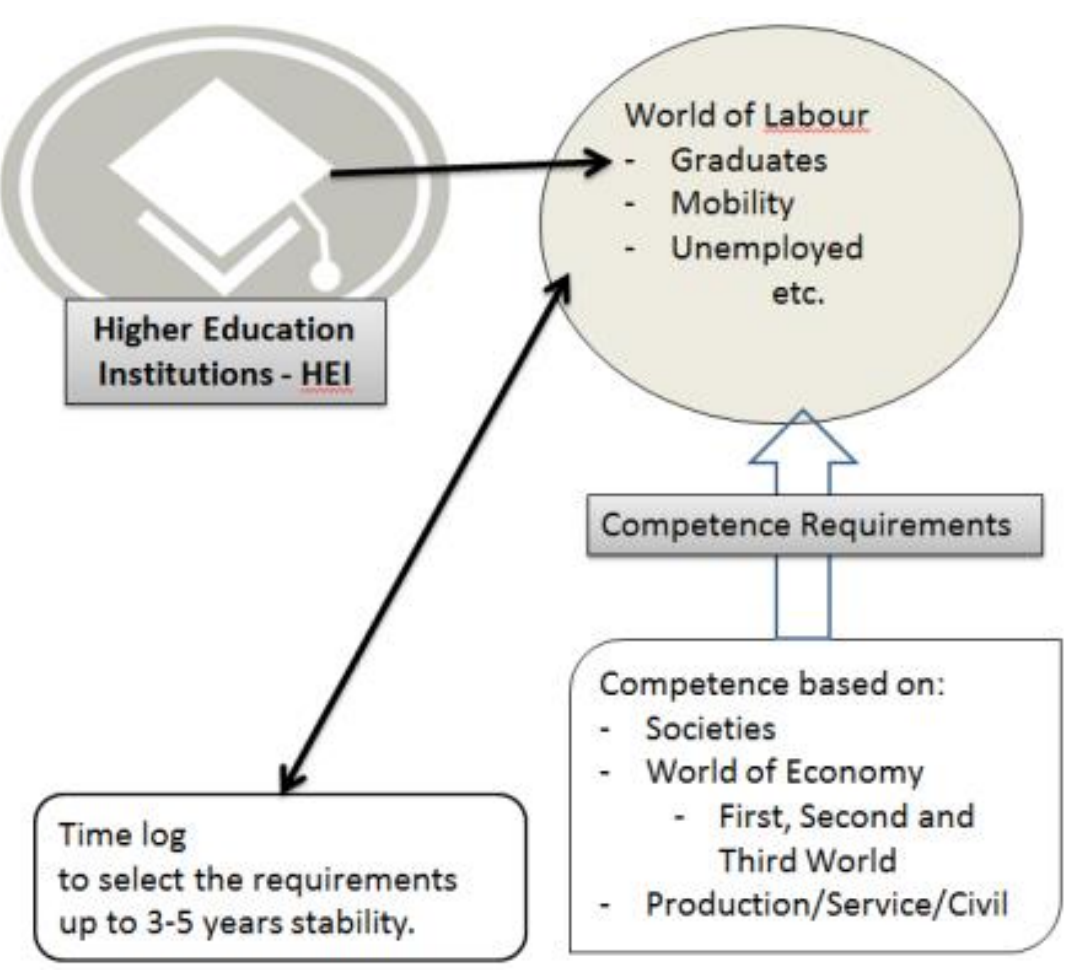

Figure 1 the relation between HEI and World of Labour

\subsection{Scope of research}

This research shares some goals stated by the EUROPE 2020 strategy. "EUROPE 2020: A strategy for smart, sustainable and inclusive growth" - in which the European Union defines their goals by 2020. The European Commission proposes the two headline targets with others, these targets are: $75 \%$ of the population aged 20-64 should be employed and 3\% of the EU's GDP should be invested in R\&D. Employment generation is one of the most important factors for the development of a country (Borbás, 2012). However, for the development of sector-specific employment, it is compulsory to develop sector-specific skilled manpower. Countries, enterprises and persons all recognize skills development as strategic goal, and consequently seek to investment opportunities into skills. In aspiring to realize the potential of skills development, they face common challenges. 
European labour market is now recovering from a very critical situation. According to the "Labour Market and Wage Developments in Europe 2015" reports, after two years of consecutive declines, in 2014 the hours worked per person employed have slightly increased. The reduction in the number of hours worked has been a key adjustment mechanism following the 2008 crisis and 2011 recession. EURES -The European Job Mobility Portal also shows that in late summer 2015, trends on the labour market continued to be favourable ${ }^{3}$. According to the Federal Employment Agency, after allowing for seasonal fluctuations, both unemployment and underemployment fell in August, and employment continued to grow. There is still solid demand on the labour market.

Developing the condition of labour industries it is now important to analyse the situation of skilled labour in EU area. The report on "Labour market shortages in the European Union-2015" shows that in several regions there are qualitative shortages, particularly relating to skills shortages and mismatch by sectors and occupations, even though there are no quantitative shortages at EU-28. In this report they also found that there is simultaneously a large share of unfilled vacancies and a high unemployment rate, caused by qualitative inconsistencies between supply and demand. These qualitative characteristics first and foremost refer to existing/missing skills, but may also be related to work experience, age, gender and work preferences. According to the National Employment Service of Hungary at the end of August 2015, more than half of the registered job-seekers were unqualified. Employers continue to report difficulties in finding enough workers with the appropriate skills. (Eurofound, 2017).

Looking the details, there were 339,000 registered job-seekers in Hungary at the end of August 2015, 15.6\% down on the previous year. However, more than half of them were unqualified, while only $6 \%$ had a degree from higher education. At the same

\footnotetext{
2 Directorate-General for Employment, Social Affairs and Inclusion, Directorate A - Analysis, Evaluation, External Relations, Unit A.5 — Labour Market Reforms

${ }^{3}$ European Commission. Directorate-General for Employment, Social Affairs and Inclusion, 2015 4 Directorate General For Internal Policies, Policy Department A: Economic And Scientific Policy, Http://Europarl.Europa.Eu/Studies
} 
time, employers reported 50,100 vacancies, 53.5\% fewer than the previous year. They also reveal "the level of recruitment difficulties varies by sector. For example, in the ICT sector, there have been more than 10,000 positions unfilled for decades. This sector, providing $10-12 \%$ of Hungarian GDP, has been expanding by $4.5 \%$ annually since the economic crisis, according to the Central Statistics Bureau (KSH), and the labour supply has not been able to keep up". (Source: www.ksh.hu)

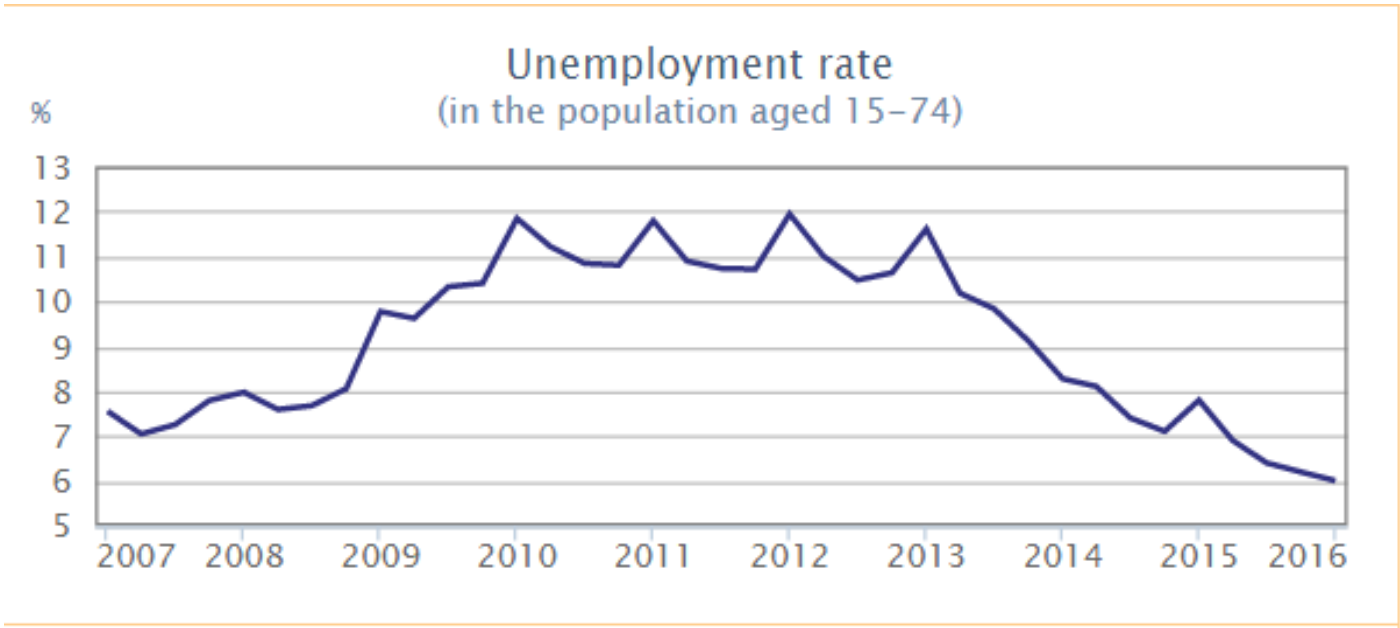

Figure 2 Unemployment rate in Hungary, Source: CSO

\subsection{Subject of research}

The goal of this research is to develop a system that is capable of predicating the future trends of jobs in different industries by following different economic scenarios and investigating the need for the development of core competencies in curricula. It is difficult to accurately predict which jobs and consequently which occupations will be demanded in the future, and how many jobs will be created in these occupations. Economic conditions, technological developments, demographics, consumer behaviours and many other factors are influencing labour market, occupational composition, and different type of future job opportunities. 


\subsection{Research questions}

The research area has led to the following research questions:

1. What will be the future jobs according to technological and economic changes of a country, or more precisely, a region?

2. What is the macro-economic impact of future job trends?

Changes in demand and supply in different segments of labour market will affect the labour market position of workers with an educational background in a related field of study. Traditionally such discrepancies between supply and demand are thought to lead to unemployment in the case of excess supply and to unfilled vacancies or skill shortages in the case of excess demand (Wieling and Borghans, 2001).

The forecasting results identified the future job trends and have inspired additional research questions:

3. How can be balanced the employment supply and demand geographicand sector wise?

4. Is higher education developing manpower for the future?

5. Is it essential to update the academic curricula for ensuring the competencies for future jobs?

Answering the research questions we need a unified view to discover skills needed by future jobs. Assuming manpower demand in large extent depend on the production/services volume and structure, first, we need to model, what is the expected production of the national or regional economy, what is the structure of the total production and how the structure is changing in time.

Input-output analysis facilitates the forecasting of number and composition of jobs in different industries. Because the goal is to develop a dynamic tool that can monitor changes continually, hence open (government) data (e.g. tables about factors influenced economic growth) will be used as input for input-output analysis. Based on the result of input-output analysis, the most important sectors will be highlighted. Different classification frameworks (like NACE, ISCO) help to connect occupational 
groups to sectors. ESCO contains competences required by occupations in a very structural manner. Competences extracted from ESCO are connected to sectors via occupational groups. The system integrated these methods and data provides opportunities to run business scenarios reflecting future economic changes affected by different factors (like economic or technological factors) in the system in order to analyse how the importance of different competences will change in the future. We are living in the era of the $4^{\text {th }}$ revolution and it is not enough just hear the prophecies about future jobs, but the educational sector have to detect the important competences in the future in order to fit the students for the future labour market needs.

Using the output of this system as an input of the SMART system (Castello et al., 2009), the compliance of educational and/or training programs with future job requirements can be analysed and reported in a meaningful and clear form. 


\subsection{Methodology of the research}

The goal of this research was to develop a system which is capable of predicating the future trends of jobs in different industries by following different economic scenarios and investigating the need for the development of core competencies in curricula. It does not fit into the world of social science research, because it did not aim to discover rules and connections that explain interferences among people (Babbie, 2001). That's why research questions and not hypotheses determine the research directions. This research aimed to create a prototype in order to help in investigating and answering these questions.

General economic rules were modeled in this prototype, hence this research required deductive thinking method (Babbie, 2001). But the analysis of the domain were datacentric, so quantitative research was executed as well (Newman and Benz, 1998).

The following steps have been performed in order to investigate applications of economic model focusing on employment.

1. First, an input-output economic model has been set up in order to be able to contextualize sector wise and occupational wise forecast.

2. Second, EUROSTAT and Hungarian Statistical Office data have been collected in a repeatable and automated fashion. Three coefficient tables have been made manually from the input-output table data.

3. Third, a programming script has been generated to find the result about future jobs.

4. Sector-wise competence sets extracted from ESCO have been integrated to these part of the system in order to finalize and prepare it to model future changes with the help of business scenarios. The results can be analysed by a business analytics software like Tableau software. 
Following steps have been followed in this research work:

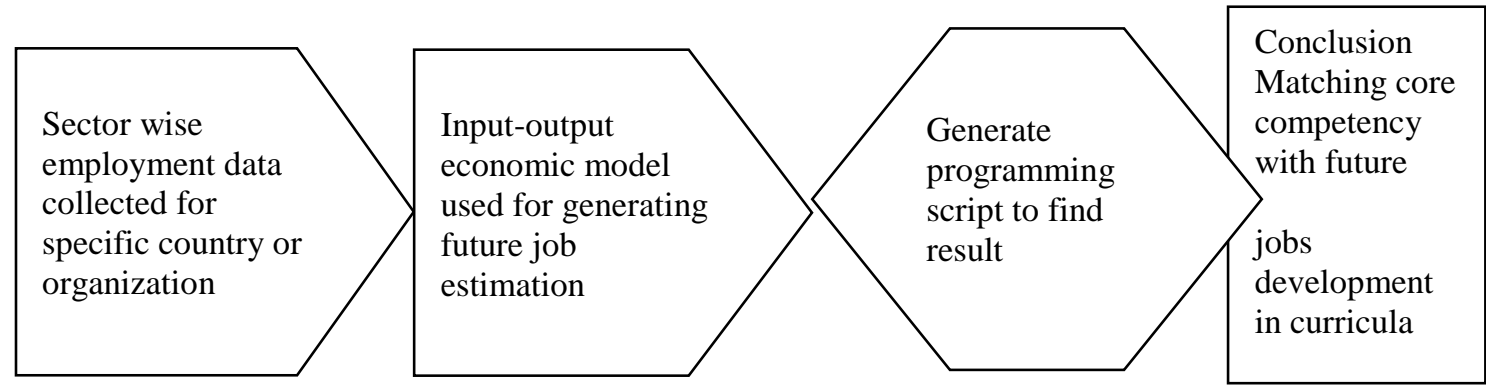

Figure 3 Research steps

\subsection{Benefits and importance of the research}

It must have a reflective relation between public and competitive sector and academia for supplying competent workforces in industries. Similarly, academia should have the knowledge about the trends of industrial changes for updating their academic curriculum. This research mainly focuses on to find the trend of sector wise industrial changes based on changing micro or macroeconomic parameters. These trends can be used by the academia to accomplish the core knowledge for building their academic portfolio. 


\section{STATE OF THE ART}

\subsection{Research background}

Different studies deal with forecasting future competences. Systematic analysis is our main goal, so approaches using models or other methods for synthetizing knowledge sources fall into our scope. Hence two research groups and two international institutions (OECD and CEDEFOP) specialized on this topic were selected to present their approaches. Their main characteristics are collected in the following table.

- Authors identify the research approach unequivocally.

- Scope presents that this a general forecast or focuses on a specialized area.

- Input shows which sources were used to build a model or determining predictions.

- Method is the key element of a research, because it reflects the reality in a restricted manner.

- Flexibility means that this research is capable of evaluating the small changes of factors.

\begin{tabular}{|c|c|c|c|c|}
\hline Authors & Scope & Inputs & Method & Flexibility \\
\hline $\begin{array}{l}\text { Hartmann and } \\
\text { Bovenschulte } \\
\text { (2013) }\end{array}$ & $\begin{array}{l}\text { Skill needs } \\
\text { prognosis } \\
\text { specifically on } \\
\text { Industry } 4.0\end{array}$ & $\begin{array}{l}\text { Experts' } \\
\text { opinions }\end{array}$ & $\begin{array}{l}\text { Virtual Technology } \\
\text { Roadmap, Organizational } \\
\text { scenarios, Quantitative and } \\
\text { qualitative skill needs } \\
\text { analysis }\end{array}$ & $\begin{array}{l}\text { Roadmap has } \\
\text { to be renewed }\end{array}$ \\
\hline $\begin{array}{l}\text { Institute for the } \\
\text { Future for } \\
\text { the University of } \\
\text { Phoenix } \\
\text { Research } \\
\text { Institute (Davis } \\
\text { et al. 2011) }\end{array}$ & $\begin{array}{l}\text { Six key drivers } \\
\text { and ten most } \\
\text { relevant skill } \\
\text { areas }\end{array}$ & $\begin{array}{l}\text { Experts' } \\
\text { foresights } \\
\text { collected during } \\
\text { a workshop }\end{array}$ & $\begin{array}{l}\text { IFTF's signals } \\
\text { methodology }\end{array}$ & $\begin{array}{l}\text { No. There are } \\
\text { not } \\
\text { quantitative } \\
\text { correlations } \\
\text { between the } \\
\text { factors }\end{array}$ \\
\hline
\end{tabular}




\begin{tabular}{|c|c|c|c|c|}
\hline Authors & Scope & Inputs & Method & Flexibility \\
\hline $\begin{array}{l}\text { OECD report } \\
(2017)\end{array}$ & $\begin{array}{l}\text { Mainly ICT } \\
\text { skills }\end{array}$ & $\begin{array}{l}\text { National } \\
\text { databases }\end{array}$ & $\begin{array}{l}\text { Skills strategy for } \\
\text { managing national skill } \\
\text { systems } \\
\text { Statistical analysis }\end{array}$ & $\begin{array}{l}\text { Possible, but } \\
\text { mainly } \\
\text { analyzing at } \\
\text { national, not } \\
\text { skill level }\end{array}$ \\
\hline $\begin{array}{l}\text { CEDEFOP's } \\
\text { European skills } \\
\text { and job survey } \\
\text { (CEDEFOP } \\
2017 \mathrm{a}-\mathrm{b})\end{array}$ & $\begin{array}{l}\text { Skill gap } \\
\text { analysis }\end{array}$ & $\begin{array}{l}\text { Questionnaires } \\
\text { filled by } 48676 \\
\text { adult employees } \\
\text { in the } 28 \mathrm{EU} \\
\text { Member States }\end{array}$ & Statistical analysis & $\begin{array}{l}\text { Analysis at } \\
\text { general skill } \\
\text { levels }\end{array}$ \\
\hline
\end{tabular}

Table 1 Studies about future competences

These studies highlighted future competences based on the experts' actual opinions about the future or statistical analyses. The first two studies contained mostly qualitative analyses, diminishing the chance to examine the role of different influencing factors. But they provide us new insights with defining new skills. The last two studies used quantitative analyses based on past data, so the changes of influencing factors can be examined within these databases. But the current skill categories served as a basis for these analysis.

The goal of this research is to develop a system for revealing the relative importance of different competences in the future. Hence it exploits the result of the previous studies, but it complements them as well. The qualitative studies must be repeated in order to detect the changes in the environment. The quantitative studies have no interest to modify their categories, because trend analysis requires strict meta-data catalogues to discover patterns or correlations along time dimensions. These approaches can complement each other and information system can synthetize their advantages. It is capable of monitoring current situations, collecting open data as past data, performing forecasts based on them, presenting the results of different business scenarios due to the changeable parameters, so it is dynamically changeable but the other ones are not. 


\subsection{Beyond the state of the art}

These studies use models to collect the experts' current thoughts about the future. They do not capitalize the benefits of information systems which are capable of formalizing experts' thinking processes, opinions to create models, continually detecting the actual situations and mixing these outcomes to get a more precise estimation.

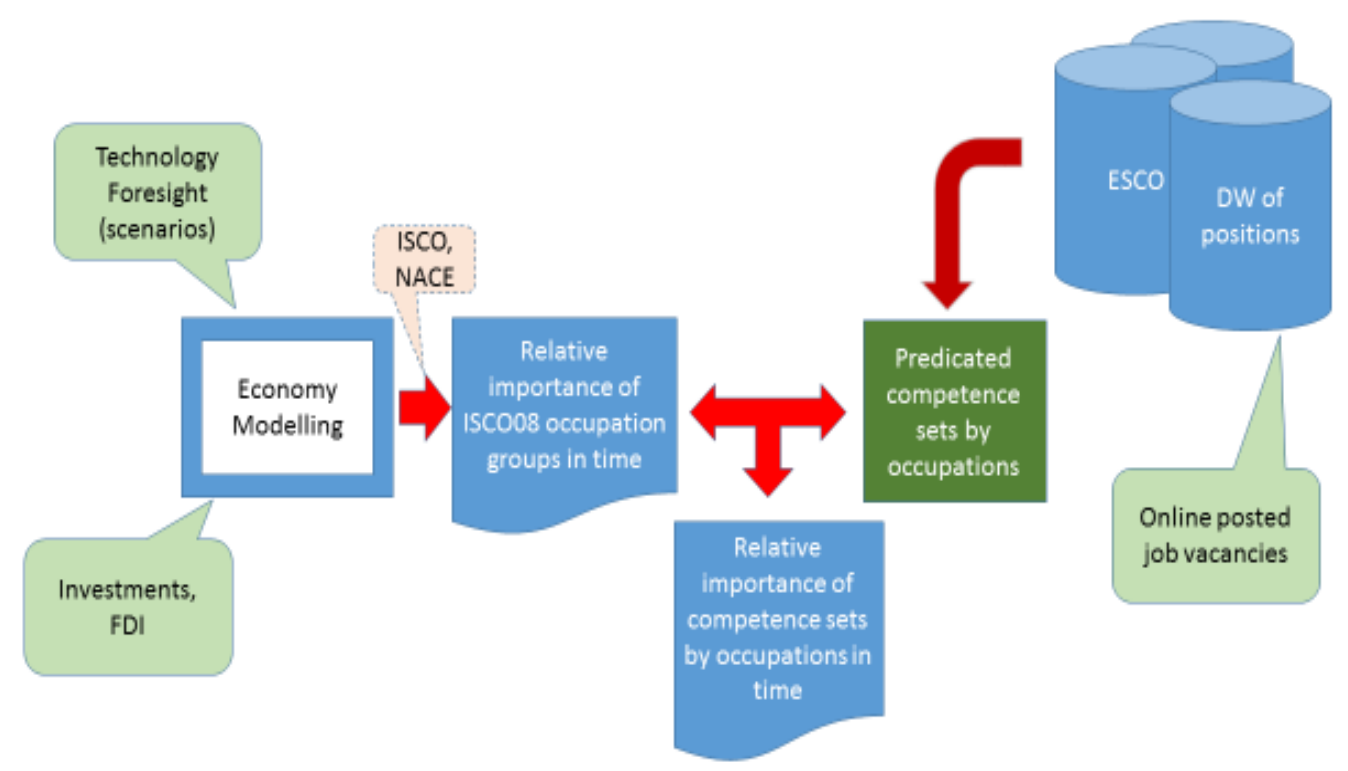

Figure 4 The "Big picture"

Different factors can influence the relative importance of future competences. Economic factors - like GDP, imports and exports can, sectoral outputs etc. - and technological innovations - like smart systems, blockchain etc. - can influence the labour intensity of different sectors. This takes effect on occupations as well. The relative importance of occupations belonging to a more labour intensive sector will increase. But competences are required to execute different tasks of these occupations. So the relative importance of these skills will grow. Input-output model developed by Leontieff suits this problem, because it is widely used to model 
industrial outputs, cross-consumptions and labour intensity. Input data of this model can be downloaded due to the Open Government Data initiative. Sectors categorized by NACE represents the industries in this model. Occupations classified by ISCO-08 are connected to these NACE sectors and their distributions are published as open data. The relative importance of different ISCO-08 groups is determined on this way.

Unfortunately the distributions of ISCO-08 subgroups per sector are not available therefore another source have to be used to estimate them.

The aim of SMART project (2012-1-ES1-LEO05-49395) (SMART, 2015) was to monitor actual competence needs via online posted job vacancies and compare them with the competences acquired during VET studies in the tourism industry. The SMART + project (2016-1-ES01-KA202-025304) (SMART PLUS, 2017), as its successor is to provide a comprehensive system for detecting skill gap for students and for institutions as well. Besides a comprehensive skill mismatch report, it provides a report concerned on just some positions. This system is capable of downloading and categorizing job vacancies by position, company, time and regional dimension, and extracting, storing competences required by the position. Another but connected research deals with creating a data warehouse from these datasets in order to monitor and analyse skill mismatches anytime and anywhere. At the end of the development process, monthly data will reside in this data warehouse (DW). ESCO (2017) helps to connect the stored positions to occupations and it presents competences per occupation which can be used to extend the above-mentioned extracted competence sets with new ones. The predicated competence sets per occupation will be calculated within the DW. Their relative importance means that we can state that a competence will be more important than another one, but we cannot state how many times it is. This relative importance will be calculated based on the predicated competence sets per occupation and the aggregated relative importance of the occupations requiring these competences within the ISCO-08. We assumed that the competence can inherit the importance of an occupation, because it is needed to execute a task and if more this kind of position is published then more this kind of task and its competences are required.

Main concepts and areas are clarified in the following sections. 


\subsection{Competences}

One of the objectives of European Union long term strategy (EU2020) is to create the Single European Market (SEM). In the context of SEM, the macro-regional mobility highlights the questions of free movement of manpower. One aspect of the free movement of manpower is the workforce knowledge, skill and attitude competences in short - compliance from the perspective of the different Member States. Member States are not only geographically different; differ significantly in terms of work culture. On corporate level, in the context of employees and employers it is a vital interest to get evidence of existing competences of the new employees, or having a timely monitored competence evolution of the staff.

There is a big terminology bonanza in this area. We are talking about competency and competences, knowledge, skill and attitude, autonomy and responsibility, job role, position and occupation, match and mismatch skills, job-seekers, free movements of manpower, migrants and refugees, mobility, career development, employability and unemployment, labour market integration and re-integration .... the list is endless.

Competences has many interpretations in the literature and academia, especially in accreditation processes. In this paper, in our understanding competence is a mix of knowledge, hard/soft and transversal skills, attitude, autonomy, responsibility. This interpretation is often mentioned as employability skills. On micro level required competences are linked to the job to be performed. From modelling point of view, jobs emphasized in tasks, and tasks are organized into business processes. Job roles, and their descriptions (in the sense what performers need to know and be able to perform the task) are part of one or more positions, connecting this way process and organisational views together.

While employers, corporates look for competences in connection with positions and connected job roles, on macro level the competences grouped and associated with occupational structure. An occupation is an element of the statistical nomenclature, 
positions and occupations are strictly linked together by administrative means. The mutual assignment is not without problems: the competence structure mirrors the present and future demand of industry, service sectors, and changes dynamically, however occupational structure is a rather rigid, follows a statistical nomenclature and changes are much less frequent. The occupational structure depends on macro structural variables, educational and training systems.

\subsection{Stakeholders /interested parties}

Competence matching is a wider issue, than many of us would have thought. Many types of stakeholders are interested in it, from different perspectives.

On supply side, first of all employers, owners and managers of individual firms play the most significant customer roles. Also different (traditional and online) manpower services either from recruiting or selection purposes are significant stakeholders, but many professional association offers also guidelines, conduct surveys in this direction. Finally, education sector, as one of the largest suppliers of graduates must know how effective they are.

On demand side we must mention graduates, employees with mobility or career exchange motivation, unemployed to be re-integrated, any job-seeker, in general. 


\section{LITERATURE REVIEW}

\subsection{Research for future jobs}

The impact of institutions on job research is an imperative theme in the ongoing process on the causes of the better performance of European labour markets. However, to date, much more emphasis has been given to the sectoral measurement for job creation. Greenwood, MacDonald \& Zhang, G. J. (1996) explained three key features of the employment process in the US economy. These are (1) job creation is procyclical, (2) job destruction is countercyclical, and (3) job creation is less volatile than job destruction. They proposed a two sector general equilibrium model both aggregate and sectoral shocks. However, in this model workers were assigned their works via lottery, stillness did not be the part of their analysis.

New technologies are having an extensive and perceptible impact on labour market. Many researches examine recent occupational projections in order to determine how new technologies will affect future job growth. Rumberger \& Levin (1985) show that the number of job openings due to death and retirement is two to three times greater than the number of openings due to employment growth for changing in technologies. Sometimes the slowdown in industrial growth of East European countries is due to a decline in the efficiency or intensity of factory utilization rather than to declining rates of growth of technological progress. As a result, the amount of labour that could be displaced during cyclical downturns is estimated and found to imply potentially high levels of veiled unemployment (Brada, 1989). Impact of technological changes in labour market also found in Institute of Public Police Research (IPPR) (Dolphin, 2015). They show that the European labour market is likely to see substantial disruption and change over the next 10 to 15 years, and that it will be less stable and secure for workers. Howell, D. R. (1985) found some bad effect in labour market for automation like use of industrial robots. We may add, this perception is getting stronger and stronger in the light of development automatization, use of artificial intelligence. His research shows that job displacement is 4.5 to 6.2 times greater than job creation that under the most extreme scenario the aggregate net job loss is 718,000 , about 0.7 percent of total employment. 
Frey \& Osborne (2013) revealed that about 47 percent of total US employment is at risk for future computerization. They examine "expected impacts of future computerization on US labour market outcomes, with the primary objective of analysing the number of jobs at risk and the relationship between an occupation's probability of computerization, wages and educational attainment".

Social networking websites (SNWs), like Facebook or MySpace, now plays an important role in the world of labour Kluemper \& Rosen (2009). Based exclusively on viewing social networking profiles, these research shows the judgments are consistent in the ratings across subjects and typically able to accurately distinguish between high and low performers. Parker \& Cordery (2001) proposed a framework for the broadening of work design that specifies some kinds of work design variables that span individual, group and organizational levels of analysis. This theoretical framework found that job satisfaction, motivation, attendance and performance will certainly remain central to the agenda for future job.

Jahoda (1981) already decades ago discussed some specific theories being exploited by adherents of one or the other dominant value positions: conservative, reformist, and radical which used for social research. In their research Morris \& Venkatesh (2000) find that measurement, compared to older workers, younger workers' technology usage decisions were more strongly influenced by attitude toward using the technology.

\subsection{Economic models for future jobs}

Many economic models have been proposed for labour market analysis. Glennon, Lane \& Johnson (1987) proposed a model for the labour market of Louisville metropolitan area. Their study attempted to improve the efficiency of forecasts by incorporating inter-industry linkages in wage and employment determination into an econometric model. Shore, Randel, Chung, Dean, Ehrhart \& Singh (2010) used Brewer's optimal uniqueness theory to develop a definition of employee inclusion in the work group as involving the satisfaction of the needs of both belongingness and 
individuality. This enclosure framework provides a basis for inspiring research on diversity that is focused on capitalizing on the unique value of diverse individuals in labour market. Economic development improves the labour demand. Lehmann and Wohlrabe (2014) described some techniques in regional economic forecasting. This technique can be used as a partial development in future jobs. An exogenous increase in the turnover rate can increase profits, but only where firms do not choose the wages. This effect of turnover varies across firms as it depends on turnover costs, the substitutability of incumbents and new hires and other factors. Garino \& Martin (2007) proved many years before by using the efficiency wage model of Salop (1979). Wages and labour turnover are the simultaneous part of an industry.

Miller \& Brickman (2004) present a theoretically grounded model of motivation and self- regulation that places personally valued future goals at its core. They effort to integrate two lines of conceiving and research that have been relatively independent of one another: the social-cognitive standpoint on self-regulation. Blundell \& Walker (1986) have given some explanation of labour market behaviour. They proposed some economic models with some technique using the nature of unemployment.

\subsection{Output model in economy}

Using the input-output model the study of Norwich and Aberdeen (1980) explain the ways to forecast gross domestic output and employment intensities in sectors. However, in calculating the employment demand in the respective country this study ignores the important parts of labour migration from one sector to another due to technological changes, rises and falls in industries, as well as requirements for skills diversification. By using input-output accounting principles and integrated bottom-up approach Jelena, Albertas and Adrian (2012) created Lithuanian macro-econometric model and to afford three forecast scenarios of mean wages and unemployment rate in Lithuania. The forecast of unemployment is interrelated to productivity ratio, export, labour force; these factors are crucial for the unemployment forecast in their 
research. This was focusing on employment or unemployment rate, not in number of employed person in individual sector.

Input-output analysis is widely used to examine the economic impact of tourism (Fletcher 1989, Frechtling and Horváth 1999). The RIMS II ${ }^{5}$ regional input-output model was employed to estimate the multiplier effects of visitors' expenditures in a region. Briassoulis (1991) attempted a classification of the methodological issues recognized in the related studies and discusses additional issues that future applications of the input-output model have to consider in tourism industry.

Some sectors depend on more labours and some are less. The change of labour productivity was analysed in terms of change in labour intensity using input-output framework (Zbranek and Sixta 2012). The method of transformation of data from the supply and use tables into the symmetric input-output tables form worn-out by commodity is used. However, they used of the ratio of direct labour inputs to output and the assumption on the average hourly wage related to the commodities. Sonis and Hewings (2007) evaluated two complementary approaches to input coefficient change, namely (i) error analysis and (ii) sensitivity analysis. While the two issues addressed separately, the distinction is, in many ways, somewhat artificial. Instead of empirical issues, some theoretical analysis they presented in this study.

Output, income and employment multipliers from the input-output table used for defining economic structure by the research of Bekhet (2011). Multipliers for income and employment were calculated and the results focused the economic condition in different sector.

The more transparent a labour market, the better the opportunities and risks resulting from future labour supply and demand developments can be signalled. To anticipate mismatches, suitable labour market forecasts are required (Cörvers 2003). The

${ }^{5}$ RIMS II : The Regional Input-Output Modeling System (RIMS II) of Bureau of Economic Analysis, USA, a regional economic model, is a tool used by investors, planners, and elected officials to objectively assess the potential economic impacts of various projects. 
Dutch Research Centre for Education and the Labour Market's (ROA) forecasts aim to improve the match between education and the labour market. Their research focused on the bottom-up and the top-down approaches by reviewing some ROA research. Some models for the whole regional labour market with regard to detailed occupational groups and types of education also presented there.

Some economic models have been proposed for forecasting labour market. Schanne (2011) proposed Global Vector Autoregressive (GVAR) models justify the link between the local and the surrounding labour market. They made coefficient region by region, not in industrial sector. Dubra and MāraGulbe (2008) proposed an econometric model for labour force demand and supply forecasting is elaborated and it comprised 120 professions, 37 aggregated groups of professions and covered time period 2007-2030. The methodology of the research was based on different surveys and statistical information, expert evaluations, mathematical statistics and econometrics. Christos (2005) made a good comparison the out-of-sample forecasting accuracy of time series models using basic statistical analysis.

The training that is provided today must be needed at some time in the future. However it is difficult to predict which training is helpful for future job. Meagher and Pang (2011) drew on a detailed analysis of the show of a labour market forecasting system built by a general equilibrium model of the Australian economy.

The big challenges for the Higher Education Institute (HEI) is to connect perfect education with employability and career development in the design of curricula and learning experiences. Many studies suggest different approach to overcome this situation. Minor (2005) suggested a curriculum for specially sector. Rae (2007) demonstrated the rationale of connecting academia, curriculum and employability. Weligamage and Siengthai (2003) was conducted a research with the objectives of identifying university graduates' job prospect, factors touching their job expectations and identifying employers' needs from university graduates. Little (2001) suggested that having any validity, indicators of graduate employability need to be seen as multi-dimensional factors relevant to obtaining a job and to preparation for work. Weligamage (2009) focused that that maximum academic portfolio researches with 
employment forecasting are survey based, no economic context has been added in that type researches.

\subsection{Educational portfolio for future jobs}

One kind of architect that invokes up a picture of something used to carry around a variety of documents designed to demonstrate one's achievements is called portfolio (Loughran \& Corrigan, 1995). Education or teaching portfolio can be viewed at least from two important aspects, one is the process view, other is the product view. The teaching portfolio is more authentic form of teacher assessment (Barton\& Collins, 1993). Academic portfolio is always important for future job. Thomas, D. S. M. (1998) described the history of portfolio for assisting learning for professional development. They discussed some current thinking about the use of portfolios for formal assessment.

Linse, Turns, Yellin \& VanDeGrift (2004) developed the Engineering Teaching Portfolio Program. They used the data of case studies to gain insight on the impact of the program and learn how to improve it. "Doctors and hospital departments with dramatic impact on morbidity and mortality figures catapulted generic competencies to the forefront of attention as indispensable qualities for doctors" (Driessen, Tartwijk, \& Dornan, 2008, pp.790-801). This research found some process for the development of professionalism and communication techniques in medical professional. Evaluating and Improving is an important method in education system (Schneider, 2004). The authors, in this report, based on a study of the National Research Council's (NRC) Committee of US on Recognizing, Evaluating, Rewarding, and Developing Excellence in Teaching propose a topdown restructuring of Science, Mathematics, Engineering, and Technology (STEM) education by means of multifaceted assessment of teaching and learning. 


\subsection{Technology affects future jobs}

Industrial robots/automation has changed the nature of manufacturing, big data and smart machines are now transforming a wide range of industries and occupations. Technology and employment researches have the most important priority within some decades. Foreign direct investment (FDI) can play a major role in the industrial development of a country and also for increasing in labour market (Barrell \& Pain, 1997). Development of manufacturing industries, there have been a correlation in FDI and job market (Chen \& Ku, 2000), Canadian manufacture industries have also some indirect economic benefit from FDI (Globerman, 1979). Main finding of this research is - minimum efficient plant size is positively related to total industry employment by using FDI.

The Educational Quality of the Workforce National Employers Survey (EQW-NES), matched with the Bureau of the Census' Longitudinal Research Database (LRD), examined the impact of workplace practices, information technology and human capital investments on productivity. They estimate an augmented Cobb-Douglas Production Function with both cross section and panel data covering the period of 1987 to 1993 using data from a unique nationally representative sample of businesses (Black \& Lynch 2001). They found that the higher the average educational level of production workers or the greater the proportion of non-managerial workers who use computers, the higher is plant productivity.

World Economic Forum research (2016) respondents about new job categories and functions that they expect to become important to industry by the year 2020. From their research they found the following employment trends in different industries for changing of technology. 


\section{TECHNOLOGICAL}

Mobile internet, cloud technology

Processing power, Big Data $26 \%$

New energy supplies and technologies $22 \%$

\section{Internet of Things $14 \%$}

Sharing economy, crowdsourcing

$12 \%$

Robotics, autonomous transport $9 \%$

Artificial intelligence

\section{$7 \%$}

Adv. manufacturing, 3D printing $6 \%$

Adv. materials, biotechnology

\section{Drivers of change, industries overall}

Share of respondents rating driver as top trend, \%

\section{DEMOGRAPHIC AND SOCIO-ECONOMIC}

Changing nature of work, flexible work $44 \%$

Middle class in emerging markets $23 \%$

Climate change, natural resources $23 \%$

\section{Geopolitical volatility $21 \%$}

Consumer ethics, privacy issues $16 \%$

Longevity, ageing societies $14 \%$

Young demographics in emerging markets $13 \%$

Women's economic power, aspirations

$12 \%$

Rapid urbanization $8 \%$

Figure 6 Drivers of change (Source: Future of Jobs Survey, World Economic Forum, 2016) 


\section{BUSINESS CASE STUDIES}

Today countries observe the continuous changes in the structure of employment due to various forces and factors in the economies. Companies progress and adjust to demand for new market offerings, technological advancement, changes and complexity in production practices ${ }^{6}$. Such changes in the economic sector necessitate the relocation, transfer and reconciliation of labour forces in the industrial production. Today the developed economies face the difficulty of labour shortages in their production areas, especially skilled labour forces is missing which can be compensated from internal and/or external sources (education, migration).

In general, employers require labour in a particular sector or in all sectors at a given wage. Different authors and researcher conceptualize labour shortage differently. Barnow, Trutko and Piatak, (2013 pp.33) define labour shortages as "a situation existing over an extended period of time in which employers were unable to hire at going wages or salaries sufficient numbers of qualified persons to fill positions for which there were budgeted funds and for which personnel were required to meet existing demands for services." The whole story describes the labour demand and storage around the world. It also discussed about factors that are affecting labour demand and supply in the job field. There are theories suggested by many researchers about the labour force. They also discussed about the problem arising in the labour market.

Following figure gives us a clear understanding on the demand and supply of labour force with their equilibrium and disequilibrium picture.

Fig. 7 shows a typical upward-sloping supply curve for labour force. When wages increase, more labours are willing to enter into the labour market and existing workers are willing to perform on higher level. As a result, supply of labour force increase in the market. Regarding the demand for labour force, at a high wage rate

\footnotetext{
${ }^{6}$ ERM case studies: The employment impact of relocation within the EU, Observatory: EMCC , Date of Publication: 18 February 2009
} 
employers are not willing to open up more employment opportunities and try to reduce the requirements for the labour as depicted in the downward-sloping demand curve. In this case, employer will generally auxiliary other factors of production for the labour force whose price has augmented. At the same time, higher labour price will push up the product price and accordingly demand for that product will decrease which in turn, will impact negatively on labour demand.

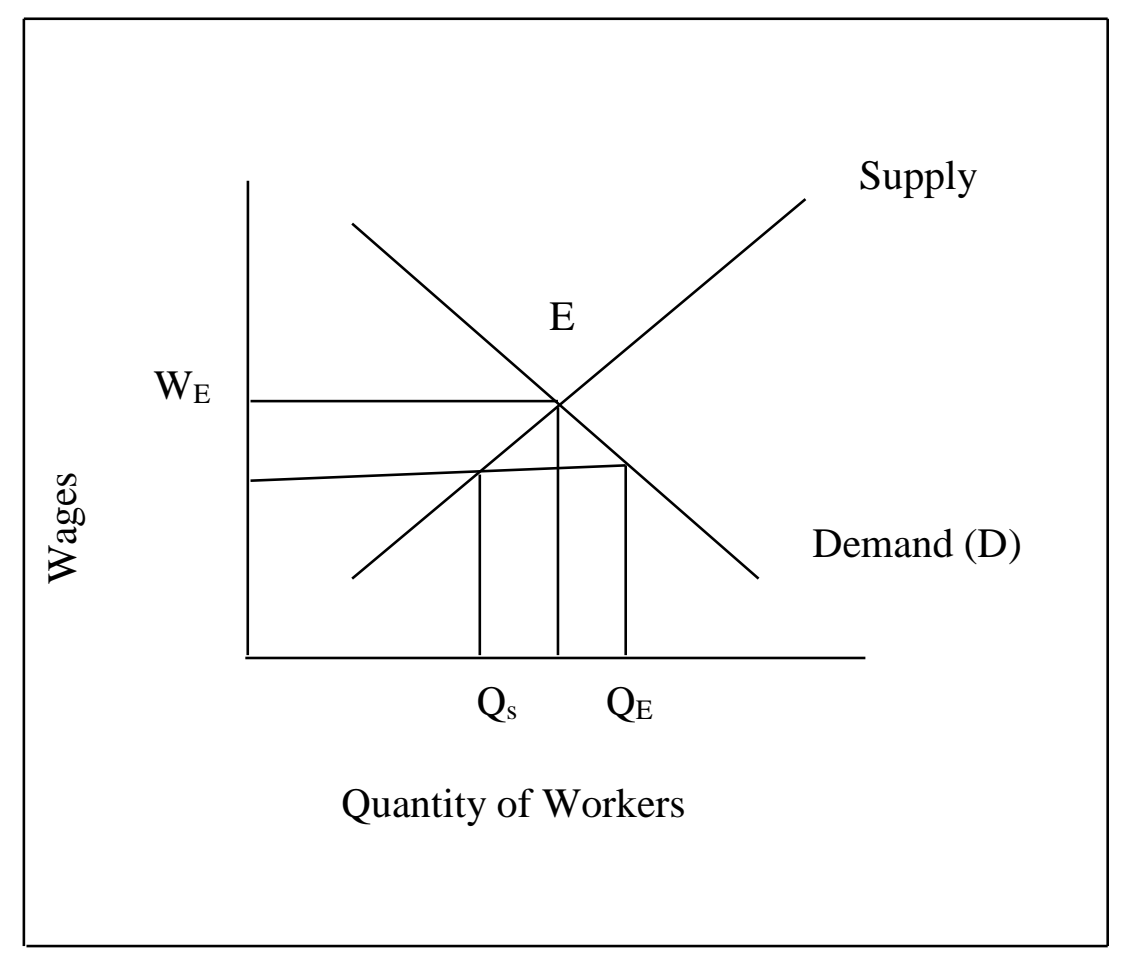

Figure 7 Illustration of a labour shortage (Source: Barnow, Trutko \& Piatak, 2013).

Label $\mathrm{E}$ indicates the equilibrium point of demand and supply of labour force at a given price. If the wage equals $\mathrm{W}_{\mathrm{E}}$ then the quantity of labour the workers are willing to supply at that wage $\left(\mathrm{Q}_{\mathrm{E}}\right)$ is exactly equals to the quantity of labour demanded by employers. In any reason, if the prevailing wage goes down to $\mathrm{W}_{O}$ then employer will demand more for the labour at $Q_{D}$ but worker will supply less labour at $Q_{s}$. As a result, shortage of labour will occur in a particular field or fields. That means the variance between the quantities of labour employers want to hire and the amount that workers are willing to supply ( $\left.\mathrm{Q}_{\mathrm{D}}-\mathrm{Q}_{\mathrm{S}}\right)$ is the amount of labour shortage.

In their study, Barnow et al. (2013) has explored several dimensions of labour shortage. They are- 
- Geographic scope of the shortage: Depending on the geographic location, demand for a particular labour may high or low. Accordingly, high regional demand may cause labour shortage.

- Longevity of the shortage: As different factors impact on the labour shortage, depending on their nature duration of such labour shortage may be shorter or prolonged, lasting for one or more years.

- Severity of the shortage: Unlike above two dimensions, it is not easy to measure the severity of labour shortage because of two reasons. First, we cannot generally observe the exact demand and supply of labour force. If we can, it is tough to measure the intensity of such gap in the market.

- Sub-specialty shortages: in some sectors some sub-specialty shortage may prevail. Because of special characteristics' of such sectors, specific labours are needed that may create labour shortage unless substitutes are available or needed forces are developed.

Economists and policy makers widely discuss three general issues regarding labour shortages (Barnow, Trutko, \& Piatak, 2013). First, because of recent decline in birth rate, some analysts are concerned that there will be too small workforce in future to maintain a developed country's economic growth. Second, there has been a growing concern that in future a serious mismatch in skills is expected where employers will not get their required skilled labour forces. On the other hand, less-skilled labour will be unemployed. As a result more vacancies and more unemployment will occur. Finally, shortage may persist in a particular sector leading to occupation-specific shortages (Barnow, 2013).

In conclusion, we can be summarized from this figure that labour supply and demands are not only affected by the wages of labour which has been provided by employers. It also depends on the shortage of needed skills of the labour and sometimes it is affected by the labour migration in different sectors. 


\subsection{Reasons why labour markets are in disequilibrium}

Labour shortage may arise because of many reasons. Following section details why a particular sector suffers from labour shortage.

Increase in the Demand for Labour: Increase in the demand for labour may happen with the increase in demand for a particular product. Because more product demand means more production and resultant increases demand for labour. Product demand may increase for many reasons. Increase in the number of consumer, higher income, favorable change in consumer taste for a product, geographical shift of population and increase in the price of other factor of production.

Decrease in the Supply of Labour: Decrease in labour supply is another reason for labour disequilibrium. Reasons may include decrease in the size of the population, existing jobs become less attractive, and restriction to entry into a particular market (Barnow, 2013).

When an economy faces labour shortage it suffers from several sides. Labour shortage create problem in the production process and availability of produce reducers in the market place. In place of decreased labour force, employer cannot utilize its resources properly. Accordingly, less optimization in resources usage happens. In place labour shortage, existing labour s need to work more hours. Such situation impact negatively on their performance and their efficiency reduces and consumers become unable to get their required items from the market place in due time. 
Following sections details some case studies on labour shortage relating to the European labour market. This discussion is broadly based on the European Foundation for the Improvement of Living and Working Conditions, 2008 report $^{7}$.

\subsection{Company cases}

European Foundation for the Improvement of Living and Working Conditions report (2008) published some case studies regarding reason for labour shortage and migration and their effect on the companies activates. Two use cases are rewritten here, where skill shortages are mostly focused.

\subsubsection{Faurecia: Sweden to the Czech Republic}

It is an international automotive parts manufacturer decided to migrate its factory from Sweden to the Czech Republic. In it they had a bad impact in their work force sector. They lost many employees. Some automatically left the company. The company had some legal problem with labour union and also with the government of Sweden. While in the Czech Republic they start their production slowly. This negativity had a huge impact on the business of Faurecia. In 2013 it is the 8th largest international automotive parts manufacturer in the world (Frigant \& Layan, 2009).

\footnotetext{
${ }^{7}$ European Foundation for the Improvement of Living and Working Conditions. (2013). Impact of the crisis on working conditions in Europe.
} 


\subsubsection{IBM Germany to Poland}

It is an American multinational technology company decided to migrate its factory from Germany to Poland. This case showed how this decision helps the company to flourishes the business of IBM in European market. Labour cost in Germany is higher than Poland. IBM grew more in Europe with this help of relocation of their factor unit.

Last we can say that before going to do any kind of manufacturing business we need to first check our demand and supply of labour in that area. This will help in many ways. Foremost it helps in cost minimization of production. This is the main motto of operation managers in a manufacturing business. Labour force can create a huge impact on the cost optimization of a product and the growth of the business in that area. (Source: ERM case studies: The employment impact of relocation within the EU, Observatory: EMCC, Date of Publication: 18 February 2009) 


\subsection{Input-Output (I/O) concept and its origins}

The Leontieff model, known as I/O analysis emphasizes the effects of change in the final demands for goods and services on particular industry with respect to its sales and purchases.

"The input-output method is an adaptation of the neoclassical theory of general equilibrium to the empirical study of the quantitative interdependence between interrelated economic activities. It was originally developed to analyse and measure the connections between the various producing and consuming sectors within a national economy... The specific structural characteristics of the system are thus determined by the coefficients of these equations. These coefficients must be determined empirically; in the analysis of the structural characteristics of an entire national economy, they are usually derived from statistical input-output tables" (Source: Encyclopedia.com, Input-Output Analysis).

\subsection{Application of Input-Output Approach}

Leontief published the first input-output table of the American economy (Leontief, 1936). John Maynard Keynes had already revived interest in aggregative economics. With the Great Depression acting as an appropriate setting for the ensuing discussion of Keynes' General Theory, the second revolution in economic thought launched by Leontief was initially a quiet one. Significant work in this new area did not occur until the 1940's when Leontief, continuing with his own efforts in inputoutput analysis, was joined by his colleagues and others in demonstrating new applications of the input-output approach, especially in the study of aggregate economic impacts. Much of the work was supported by the U.S. Bureau of Labour Statistics. In 1944, the first practical application of the input-output approach was demonstrated in estimating the effects of shifting from war to peace on employment 
(Cornfield, J., Evans, W. D., \& Hoffenberg, M. 1947). Within the next two decades, national, and even regional, input-output models had become common. Phil Borque, in his survey of state and regional input-output models published in 1970, listed all but 38 states as having work completed or in process (Cornfield, Evans \& Hoffenberg 1947). Minnesota was included in this list twice - once for the 1966 Itasca County input-output model completed by Jay Hughes, and second time for the year 1963.

To be of use and with this in mind, Leontief's early extensions of input-output analysis were intended to demonstrate that:

(1) Production coefficients, which express relationships among the industrial sectors of an economy, lend themselves to statistical estimation;

(2) The estimated coefficients are sufficiently stable so as to be used in comparative static analyses, i.e., different equilibrium states; and, given the above two points,

(3) The merits of different economic policies can be quantitatively evaluated through consideration of either their direct and indirect feedback effects (or multiplier impact) on inter-industry flows.

For the purpose of applying and extending field of input-output analysis, Leontief founded the Harvard Economic Research Project in 1948 and served the project as director for 25 years. During his tenure of service, development in interregional input-output analysis was obvious. In addition, Leontief introduced capitalcoefficient matrices meant in order to describe the investment response to changes in final demand that may arise in a particular sector. Due to these developments, inputoutput analysis came up as a skilled weapon in generating a forecasted growth path of an economic system and its diverse static equilibrium positions. From his leadership period, two notable books published, namely The Structure of American Economy 1919-1939, (1951), and Studies in the Structure of the American Economy (1953). 


\subsection{Acceptance of input-output model}

Leontieff gave an extended interpretation to the coefficients the most important among them were the following: the coefficients have a statistical character, therefore they can be estimated; different coefficients based on the estimation statistically are quite stable, hence the model is suitable for different kinds of analyses, like assumption of different economic growth, changes in industry structure, etc.; the analyses may lead to quantitative evaluation of different economic policies, comparison of their indirect effects, accelerator effects or counter effects.

Later in the light of quite different economic theories and also due to the radical changes of global economy, many argued that I/O model has not reflect anymore objectively to the real life of national economy. However the coefficients - in other word technological matrix - are based on statistical data and still the most reliable although not the only data source for modelling. Adding to the model the capital investments, taking into account the modification effects of export-import activities, the $\mathrm{I} / \mathrm{O}$ model still gives a good starting point for analysis. On the basis of the model results environmental effects, ecological considerations, the strengthening of third sector will be more understandable and lead to a more complex approach (Stilwell \& Minnitt 2000).

From the perspective of this paper we must emphasize the biggest advantages of using I/O model that is it can be built on official statistical data. The validity of data ensured by the national and macro-regional statistical data collection systems, and most of them is available in 'open data' format. The later mentioned feature means, the experiments; analyses can be reproduced in an automated fashion. 


\section{INPUT-OUTPUT COEFFICIENT ${ }^{8}$}

\subsection{Input coefficients}

Input coefficients represent the proportion of raw materials used per sector, depending on how much each sector uses to grow a production unit per sector. Unit prices are obtained by dividing input quantities from the domestic production value of the sector. The list of input coefficients for each sector is called Input Coefficient Table. Input and output tables are basically commodity-based tables. In the table, the sectors, including the endogenous sectors indicated in the top and side columns, show the goods and services provided by individual industries, government service providers, non-profit producers and households.

\section{Stability of Input Coefficients}

1) It is assumed that the consistency between the production technology levels behind the input and output tables, and the inputs required to produce the goods and services affected by the input coefficients are not significantly fluctuated in the time elapsed between the year under study and the editing of the table. In short, the input coefficients reflect the production technologies adopted in the given year. Changes in production technologies can of course change the input coefficients, although drastic changes are generally not expected, production technologies can change rapidly within a short period of time. Rapid technological developments might require appropriate adjustment of input coefficients.

2) The consistency of the production level in all industries is determined by the total production levels of different enterprises and other production entities. Even if the same products are produced in different lot sizes, it will inevitably lead to different input coefficients due to different technologies and economics levels. Input and output tables are edited to reflect the economic structure of the years under review. In

\footnotetext{
${ }^{8}$ This chapter is based on the publication of "The Japanese Economy and the 2005 Input-Output Tables", published by the Director-General for Policy Planning, Ministry of Internal Affairs and Communication, Japan, 2009. http://www.soumu.go.jp/main_content/000327480.pdf
} 
input and output analyses, the corporate structure of each sector is assumed not to change significantly between the time of data collection and analysis.

3) Variable factors of input coefficients. We assume that there is little change in the input coefficients between the year under review and the year of compilation. However, in addition to paragraphs (1) and (2) above, the following factors may change over time:

a. Change of relative prices. Since individual transactions in Basic Transaction Tables are set in the year of compilation of tables, changing the relative prices of goods and services will change the input coefficients, even if the technological structures remain constant. Linked Input-Output tables used for historical comparison are based on fixed prices, in which the effects of volatile relative prices will cease to exist.

b. Changes in product mix. If products with different input structures and unit prices go to the same sector (called product portfolios), the change in product structure within the industry will change the input coefficients of the entire sector, even if there are no changes in the input structure or unit price at the level of an individual product.

\subsection{Inverse matrix coefficients}

Relating to the domestic market, the coefficients of the inverse matrix of input-output tables describe the sales and purchasing relationships between producers and consumers in the domestic economy. The coefficients may illustrate the final and/or intermediate sales and purchase flow, or the final and/or intermediate sale and purchase of the products. The Leontief Inverse Matrix (E-A $)^{-1}$ shows the increase in output in each sector as a percentage of increase in final demand. ' $A$ ' indicates the input coefficient matrix from the I/O table. 


\subsection{Labour input-output analysis coefficients}

In input-output analyses it is assumed that the input coefficients are stable and there is no significant difference between the time of table compilation and the time of the analyses. Similar assumptions are applied in regard to labour consumption; the labour input coefficients are assumed to be stable. In our experience, however, unlike input coefficients, labour input coefficients are not always stable. For example, even if the production doubled in a particular sector, labour input would not necessarily be doubled if industrial robots were installed or operating ratios improved. In order to carry out labour-related input-output analyses, account should be taken of the changes in employment ratios and productivity as much as possible. 


\section{BASIC ASSUMPTIONS OF INPUT-OUTPUT ANALYSIS}

In order to transform the input-output table into an input-output model it is necessary to convert the table into a technical coefficients matrix. Basic Transaction Table shows the structure of the input-output transaction table. Note, that the table has three main sections:

1. the primary input quadrant which shows how each productive sector purchases its labour, imports goods and services, the taxes it pays to the government and the profits generated from their business activity;

2. the productive sector quadrant which demonstrates how each industrial sector buys and sells to each other industrial sector; and

3. the final demand quadrant which shows how each of the various elements of final demand purchases from each of the productive sectors. 


\subsection{Basic transaction table}

\begin{tabular}{|c|c|c|c|c|}
\hline & Industry-1 & Industry-2 & $\begin{array}{l}\text { Final } \\
\text { demand }\end{array}$ & $\begin{array}{l}\text { Total domestic } \\
\text { products }\end{array}$ \\
\hline Industry - 1 & $\mathrm{X}_{11}$ & $\mathrm{X}_{12}$ & $\mathrm{Y}_{1}$ & $\mathrm{X}_{1}$ \\
\hline Industry -2 & $\mathrm{X}_{21}$ & $\mathrm{x}_{22}$ & $\mathrm{Y}_{2}$ & $\mathrm{X}_{2}$ \\
\hline $\begin{array}{l}\text { Gross value } \\
\text { added }\end{array}$ & $\mathrm{V}_{1}$ & $\mathrm{~V}_{2}$ & & \\
\hline $\begin{array}{l}\text { Total domestic } \\
\text { product }\end{array}$ & $\mathrm{X}_{1}$ & $\mathrm{X}_{2}$ & & \\
\hline
\end{tabular}

Table 2 Basic Transaction Table

To transform this transactions table into a technical coefficients matrix, each cell in the productive sector quadrant and primary input quadrant must be divided by the total input value for each corresponding column. Once constructed, the technical coefficients matrix shows the proportion of inputs that must be purchased by each sector in order to produce one unit of output. At this stage of the model's construction, it is possible to assess the quantity and distribution of intermediate and primary inputs demanded directly. This is the direct effect. But, as the model clearly demonstrates, an increase in the final demand for one sector's output will cause the demand for other sectors output to increase, because of the inter-sectorial purchases. These repercussion effects, or secondary effects represent what is known as the indirect effect. The lengthy and tedious task of tracing the secondary effects by reference to the technical coefficients matrix can be replaced by a much simpler method of applying a technique known as the Leontief Inverse. The Leontief inverse, or the inverted technology matrix, is a table which shows the direct plus indirect effect of a change in any category of final demand. 
Let,

$$
\begin{aligned}
& \mathrm{I}=\text { the identity matrix } \\
& \mathrm{A}=\text { an } \mathrm{n} \times \mathrm{n} \text { matrix of technical coefficients } \\
& \mathrm{X}=\text { an } \mathrm{n} \times 1 \text { vector of gross output } \\
& Y=\text { an } \mathrm{n} \times 1 \text { vector of final demand }
\end{aligned}
$$

Then,

$$
(\mathrm{I}-\mathrm{A}) \mathrm{X}=\mathrm{Y}
$$

Which can be written as,

$$
X=(1-A)^{-1} Y
$$

Where $(\mathrm{I}-\mathrm{A})^{-1}$ is the inverted technology matrix.

\subsection{Input coefficient table}

\begin{tabular}{|l|ll|}
\hline & Industry - 1 & Industry - 2 \\
\hline Industry - 1 & $\mathrm{a}_{11}$ & \\
Industry - 2 & $\mathrm{a}_{12}$ \\
\hline Gross value added & $\mathrm{a}_{21}$ & $\mathrm{a}_{22}$ \\
\hline Total domestic & 1.0 & $\mathrm{v}_{2}$ \\
product & & \\
\hline
\end{tabular}

Table 3 Input Coefficient Table 


$$
\text { Note: } \mathrm{a}_{\mathrm{ij}}=\frac{\mathrm{x}_{\mathrm{ij}}}{X_{j}} \quad \mathrm{v}_{\mathrm{ij}}=\frac{\mathrm{v}_{\mathrm{j}}}{X_{j}}
$$

$\left[\begin{array}{ll}a_{11} & a_{12} \\ a_{21} & a_{22}\end{array}\right]\left[\begin{array}{l}X_{1} \\ X_{2}\end{array}\right]+\left[\begin{array}{l}Y_{1} \\ Y_{2}\end{array}\right]=\left[\begin{array}{l}X_{1} \\ X_{2}\end{array}\right] \quad \mathrm{A}=\left[\begin{array}{ll}a_{11} & a_{12} \\ a_{21} & a_{22}\end{array}\right] \quad$ this is referred to as the input coefficient matrix.

Inverse Matrix Coefficients:

$\left[\begin{array}{ll}a_{11} & a_{12} \\ a_{21} & a_{22}\end{array}\right]\left[\begin{array}{l}X_{1} \\ X_{2}\end{array}\right]+\left[\begin{array}{l}Y_{1} \\ Y_{2}\end{array}\right]=\left[\begin{array}{l}X_{1} \\ X_{2}\end{array}\right]$

Where $(\mathrm{I}-\mathrm{A})^{-1}=\left[\begin{array}{cc}1-a_{11} & -a_{12} \\ -a_{21} & 1-a_{22}\end{array}\right]$ 


\subsection{Inverse matrix coefficients (handling of imports)}

In analyses of production repercussions with Input-Output Tables, a major issue is handling the import. Basically various goods are imported and consumed in parallel with domestic products in industries and households.

Basic Transaction Table with Import shows the model for Basic Transaction Tables, clearly indicating imports. For row items, both intermediate demand $\left(\mathrm{X}_{\mathrm{ij}}\right)$ and final demand $\left(\mathrm{F}_{\mathrm{i}}\right)$ are supplies including imports, and columns and rows (production) offset each other because imports are indicated negative values.

Inverse Matrix Coefficient Handling of Imports:

\begin{tabular}{|l|ll|l|l|l|}
\hline & $\begin{array}{l}\text { Industry-1 } \\
\text { Industry-2 }\end{array}$ & Final demand & Import & $\begin{array}{l}\text { Total domestic } \\
\text { products }\end{array}$ \\
\hline Industry - 1 & $\mathrm{x}_{11}$ & $\mathrm{x}_{12}$ & $\mathrm{~F}_{1}$ & $-\mathrm{M}_{1}$ & $\mathrm{X}_{1}$ \\
Industry - 2 & $\mathrm{x}_{21}$ & $\mathrm{x}_{22}$ & $\mathrm{~F}_{2}$ & $-\mathrm{M}_{2}$ & $\mathrm{X}_{2}$ \\
\hline $\begin{array}{l}\text { Gross value } \\
\text { added }\end{array}$ & $\mathrm{V}_{1}$ & $\mathrm{~V}_{2}$ & & \\
\hline $\begin{array}{l}\text { Total } \\
\text { domestic } \\
\text { product }\end{array}$ & $\mathrm{X}_{1}$ & $\mathrm{X}_{2}$ & & & \\
\hline
\end{tabular}

Table 4 Inverse Matrix Coefficient Handling of Imports

Here,

$\mathrm{X}=$ an $\mathrm{n} \mathrm{X}_{1}$ vector of gross output

$\mathrm{Y}=$ an $\mathrm{n} \mathrm{X}_{1}$ vector of domestic final demand

$\mathrm{E}=$ an $\mathrm{n} \mathrm{X}_{1}$ vector of Export

$\mathrm{F}=$ an $\mathrm{n} \mathrm{X}_{1}$ vector of Final Demand $(\mathrm{F}=\mathrm{Y}+\mathrm{E})$

$\mathrm{M}=$ an $\mathrm{n} \mathrm{X}_{\mathrm{n}}$ matrix of technical coefficients of imports 


$$
\begin{aligned}
& A X+Y+E=X \\
& a_{11} X_{1}+a_{12} X_{2}+F_{1}-M_{1}=X_{1} \\
& a_{21} X_{1}+a_{22} X_{2}+F_{2}-M_{2}=X_{2} \\
& A X+F-M=X \\
& X-A X=F-M \\
& (I-A) X=F-M \\
& X=(I-A)^{-1}(F-M)
\end{aligned}
$$

Import coefficient by row: $\mathrm{m}_{\mathrm{i}}=\frac{M_{i}}{\sum_{j} a_{i j} \mathrm{X}_{\mathrm{j}}+\mathrm{Y}_{\mathrm{i}}}$

$\sum_{j} a_{i j} \mathrm{X}_{\mathrm{j}}+\mathrm{Y}_{\mathrm{i}}+\mathrm{E}_{\mathrm{i}}-\mathrm{M}_{\mathrm{i}}=\mathrm{X}_{\mathrm{i}}$

$\mathrm{M}_{\mathrm{i}}=\mathrm{m}_{\mathrm{i}}\left(\sum_{j} a_{i j} \mathrm{X}_{\mathrm{j}}+\mathrm{Y}_{\mathrm{i}}\right)$

$\mathrm{X}_{\mathrm{i}}-\left(1-\mathrm{m}_{\mathrm{i}}\right)\left(\sum_{j} a_{i j} \mathrm{X}_{\mathrm{j}}=\left(1-\mathrm{m}_{\mathrm{i}}\right) \mathrm{Y}_{\mathrm{i}}+\mathrm{E}_{\mathrm{i}}\right.$

The diagonal matrix $\widehat{M}=\left[\begin{array}{ccc}m_{1} & \cdots & 0 \\ \vdots & \ddots & \vdots \\ 0 & \cdots & m_{n}\end{array}\right]$

$[\mathrm{I}-(\mathrm{I}-\widehat{M}) \mathrm{A}] \mathrm{X}=(\mathrm{I}-\widehat{M}) \mathrm{Y}+\mathrm{E}$

$\mathrm{X}=[\mathrm{I}-(\mathrm{I}-\widehat{M}) \mathrm{A}]^{-1}((\mathrm{I}-\widehat{M}) \mathrm{Y}+\mathrm{E})$ 


\section{DATA COLLECTION}

\subsection{Data sources - Open Data / Open Government Data / GOD}

\subsubsection{Central Statistical Office (CSO), Hungary}

The data on persons employed in the Hungarian economy, according to NACE Rev. 2 (2008) 9 classification, is published by the Hungarian Central Statistical Office on its website together with other information of the national accounts. The information on persons relating to national account is important mainly for the calculation of the ratio, value added per worker in each industry of the national economy (Zbranek and Sixta, 2012).

\subsubsection{Eurostat}

EUROSTAT provides industry-by-industry symmetric input-output tables. Hungarian data in ESA 1995 format was used from their data source. The output matrix is an object as it is structured by industry. This organization presents supply and use tables and symmetric input-output tables that are a fundamental part of the European System of Accounts (ESA 1995).

\footnotetext{
${ }^{9} \mathrm{NACE}$ is the statistical classification of economic activities in the European Community which imposes the job classification uniformly within all the member states of European Union. NACE Rev. 2 reflects the technological developments and structural changes of the economy, enabling the modernization of the community statistics and contributing, through more comparable and relevant data at both community and national level. (Source: /rio.jrc.ec.europa.eu)
} 


\subsubsection{OECD}

The Organization for Economic Co-operation and Development (OECD) is involved for preparing Inter-Country Input-Output (ICIO) tables which based on different International Standard Industrial Classification of all economic activities (ISIC) revised version. The previous OECD national Input-Output tables present matrices of inter-industrial flows of goods and services (produced domestically and imported in current prices (USD million), for all OECD countries including 28 members of European Union and G20 economies, covering the years 1995 to 2011 based on the ISIC Revision 2.

The latest version of ICIO tables are based on ISIC revision version 3. The better integration with collections of statistics accumulated according to industrial activity such as research and development expenditure, employment, foreign direct investment and energy consumption. The OECD I/OT database is a very useful experiential tool for economic research and structural analysis at the international level as it highlights inter-industrial relationships covering all sectors of the economy.

\subsubsection{World Input-Output Database (WIOD)}

The World Input-Output Database (WIOD) is the first public database that contains new information on the nature of international trade and trends and provides the opportunity to analyse the consequences of division for shifting patterns in demand for skills in labour markets. These tables have been put up in a clear conceptual framework on the basis of officially published input-output tables in concurrence with national accounts and international trade statistics. In addition, the WIOD provides data on labour and capital inputs at industry level. (Source: wiod.org) 


\subsubsection{Concluding to demand}

As it was outlined in the previous sections, the I/O model is used to do predictions on the changes of occupational structure, due to the economic growth, changes in productivity and the expected technological developments. In order to get the results, the gross domestic output per sector, used labour force / output unit, distribution of labour force / sector / occupation will be used as variables. With the help of ESCO ontology and database we conclude to the expected competences / occupation. Difference between the expected and supplied competencies already provides sound basis of portfolio decisions.

\subsection{Data Pre-Processing}

\subsubsection{Input-Output (IO) Table Data in Excel Format}

Input-Output table data can be collected in Microsoft Excel format from EUROSTAT data source. In the ESA 2010, the product-by-product input-output table is the most important symmetric input-output table. However, a few countries in the EU prefer to compile industry-by-industry tables. Table need to be rearranged of the columns as follows the structure of NACE Rev. 2 Industry description (Table-1). 


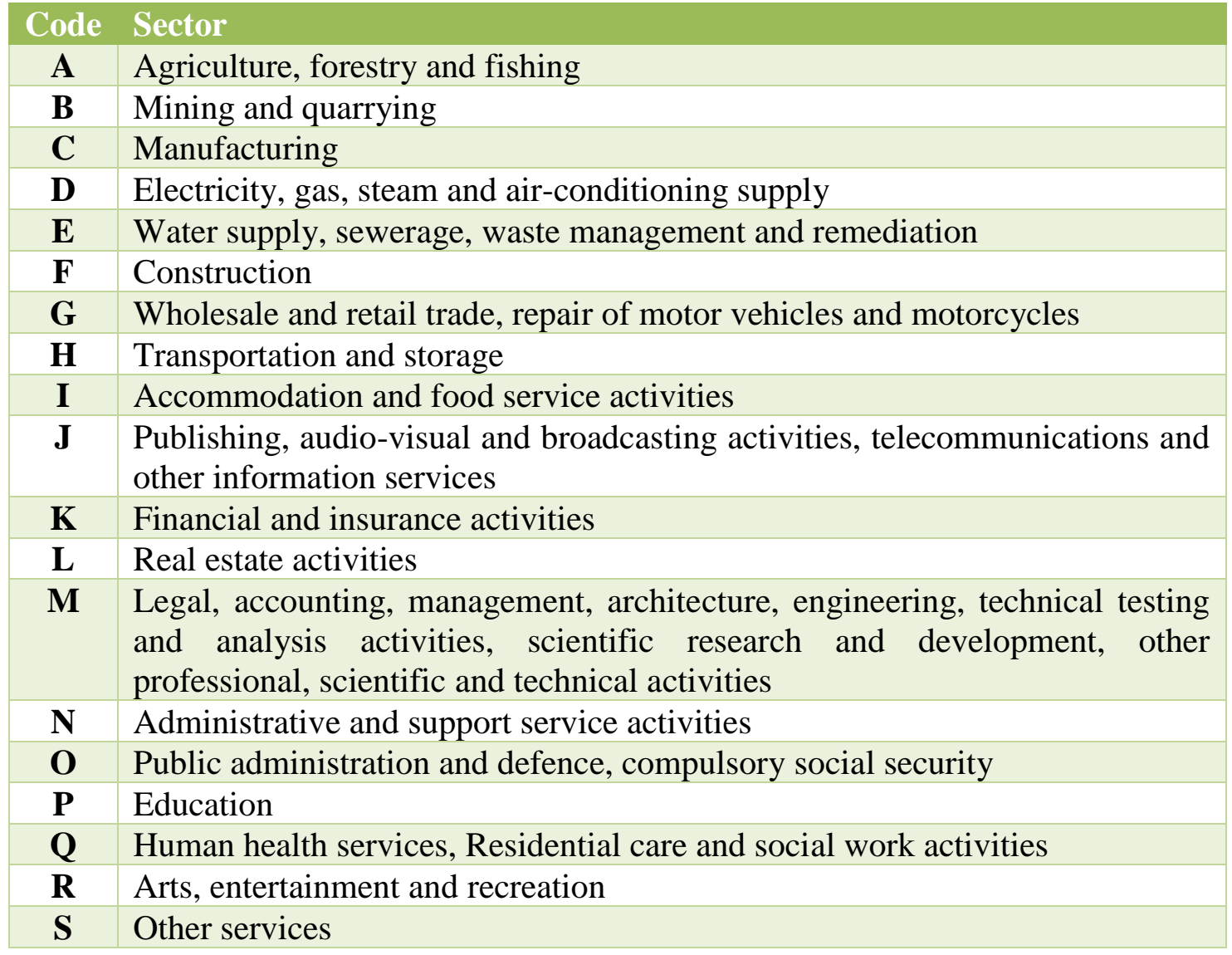

Table 5 Industry descriptions

The above outlined method of estimation of the input-output table and the development of the labour estimation was used for the selected year 2008 on the data for the Hungarian economy. 2009 data for the final domestic demand used for the second year labour estimation. Additional yearly data can be used in same format. The results in the research will be presented in aggregated form on the level of the sections of the classification for sake of clarity. In the result graph; all sections is being expressed using placeholders in form of letters. (Table-2 Supply and use table at basic prices including transformation into purchasers' prices by using NACE Rev. 2 main industries classification. See Annex)

\subsubsection{Input Coefficient from the I/O table}


The input coefficient table can be referred to as the basic production unit table. The sum of input coefficients including the gross value added portion in each sector is defined in Chapter 6. This series of calculations is made for Basic Transaction Tables for 19 sectors in the 2008 Input-Output Tables. Table-3 Input coefficient Table. See Annex)

\subsubsection{Import coefficient from the IO table}

The diagonal matrix assumed to have an import coefficient as the diagonal element and zero as the non-diagonal element. (Annex Table-4 Import Coefficient Table)

\subsubsection{Labour coefficient from the Hungarian Statistical Data}

Annex Table-5 Labour Coefficient Table.

\subsubsection{Occupation coefficient from the ISCO dataset}

\begin{tabular}{|l|l|}
\hline Occupation Name & Code \\
\hline Managers & 1 \\
\hline Professionals & 2 \\
\hline Technicians and Associate Professionals & 3 \\
\hline Clerical Support Workers & 4 \\
\hline Services and Sales Workers & 5 \\
\hline Skilled Agricultural, Forestry and Fishery Workers & 6 \\
\hline Craft and Related Trade Workers & 7 \\
\hline Plant and Machine Operators and Assemblers & 8 \\
\hline Elementary Occupations & 9 \\
\hline
\end{tabular}

Table 6 Occupation coefficient Table. See Annex 


\subsubsection{Competences from ESCO10}

\subsubsection{What is ESCO?}

ESCO stands for 'the European Skills, Competences and Occupations taxonomy'. This is also known as a multilingual ordering of professions, expertise and qualifications.

ESCO: the common language between the labour market and education/training

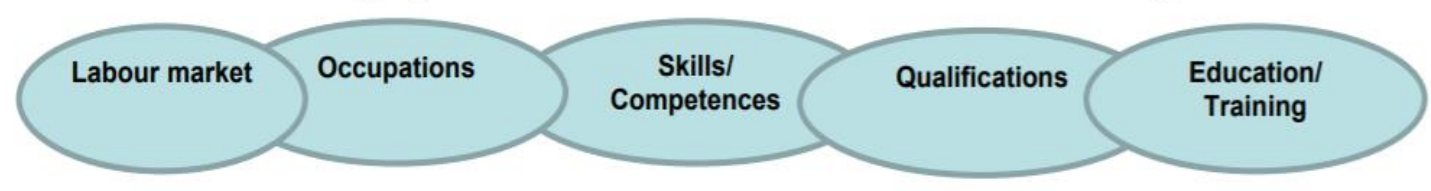

Figure 8 ESCO framework (Source- http://euhap.eu)

\subsubsection{Why is ESCO being developed?}

Employers pay attention to a good number of features to make it sure that their employees are qualified and skilled to apply their knowledge in practice and give importance to transversal skills which include learning-interest and initiative-taking that make employees approaches complementary to those of employers. With the passage of time, education and training system have also met noticeable changes, such as: output approach (i.e. earned knowledge, skills and competence) is now more important than input approach (i.e. duration and place of learning). Member States of European Union (EU) are following the strategies of European Qualifications Framework (EQF) to set up National Qualification Frameworks (NQF) which refers to qualifications as the learning outcomes not as the learning inputs. According to many Member States, development in the system has been essential in order to cope with the advancements and to improve supply and demand relationship; otherwise, it would be difficult to classify professional expertise properly and enable such skills and abilities to have any connection between required qualifications and occupational scopes. Some initiatives have been taken at sectoral level. A report

10 Competences from ESCO chapter was written as follows the portal of ESCO Europe:
https://ec.europa.eu/esco/portal 
(New Skills for New Jobs) (NeksNeJo, 2015) published by of the European Commission suggests the development of 'a common language between education/training and the world of work'. This proposition has been acknowledged by another report of European Commission titled 'Europe 2020: A European strategy for smart, sustainable and inclusive growth' which led the Education Council in 2013 to adopt its conclusion and give a call for a common language and an operational device. 


\subsubsection{Who is developing ESCO?}

DG Employment and DG Education and Culture are working in tandem for the development of ESCO. Main purpose of this project is to establish a multilingual European taxonomy of Skills, Competences, qualifications and Occupations (ESCO) which will supplement the needs of Member States who have not developed their own classification strategies and will provide support to link the existing national classifications with the sectoral ones. Through these steps, ESCO can frame a standard European terminology - a common language - which will enable the EU countries to develop their employment, education and training policies, expand their scopes in the European labour market and design a European learning phase to promote geographical and career mobility. It is noteworthy that this programme will also help analysis and understand the labour market demands and facilitate learning/training outcomes to match the professional opportunities - ultimately, it will lead to the implementation of EQF (EQF, 2009). 'DG Employment, Social Affairs and Inclusion' is responsible for the management of further development and updates of ESCO classification. In order to achieve the aim, it is backed by external organizations and the 'European Centre for the Development of Vocational Training' (CEDEFOP) (ESCO Board, 2017).

\subsubsection{ESCO Teamwork}

Developing ESCO as a modern, practical and convenient instrument will require the participation of all from education and training sectors and also those engaged with the labour market. Stakeholders' contributions to the advancement of the classification include:

- employment functions

- providers of job boards, social media, HR software or career guidance services

- $\quad$ social partners 
- education and training institutions

- $\quad$ statistical organisations, researchers and big data analysts

- Skills councils and networks

The Commission assigns the development programmes to stakeholders and Member States in several ways:

- The ESCO Member States Working Group consists of representatives of different departments from Member States, such as: officials and authorised bodies who are working on employment, education and training affairs and also those who are working as European social partners. It provides the Commission with advice and suggestions on the implementation and improvement of ESCO and ensures its information and support exchange functions with the national classification approaches on employment;

- The ESCO Board was comprised of leading and experienced representatives from the related stakeholders and provided the project with strategic over a 5-year period between 2011 and 2016;

- The members of ESCO Maintenance Committee are technical classification experts. Its tasks involve developing and assuring the quality of process;

- The Sectoral Reference Groups were made up of sectoral experts working on the labour market, education and training sectors and served the project with input for the development of ESCO v1 between 2011 and 2015;

The Cross-Sector Reference Group has skilled representatives from employment and education sectors to maintain the standards of classifications and required knowledge of education and training that match the labour market scopes. In other words, this body observes the cross-sectoral skills and competences and examines whether the qualification pillar copes with the consistency of the skills and competences pillar.

In an online-based consultation platform, expert stakeholders gave their opinion about professional profiles in 2015 and 2016. (ESCO Board, 2017) 


\subsubsection{ESCO strategic framework}

ESCO has been designed to be part of an emerging Semantic Web contributing to the development of education and training sectors and labour market. The purpose of setting up the Semantic Web is to turn the internet into a great platform where information regarding job vacancies, necessary documents and standardised professional training materials will be available. Such data are reusable and can be used in developing applications for job searching and matching portals, HR systems, professional guidance and statistical analysis- which can lead ESCO to find pragmatic approaches and solutions to the problems. (le Vrang et al., 2014)

Through transparency tools, ESCO comes up with an adequate supply of information related to labour market, education and training. Its approaches ensure that data is open to all and the developed programmes can be used by a large number of owners of practical applications and labour market systems, facilitating the services (see Fig. 1). (ESCO Boards, 2017)

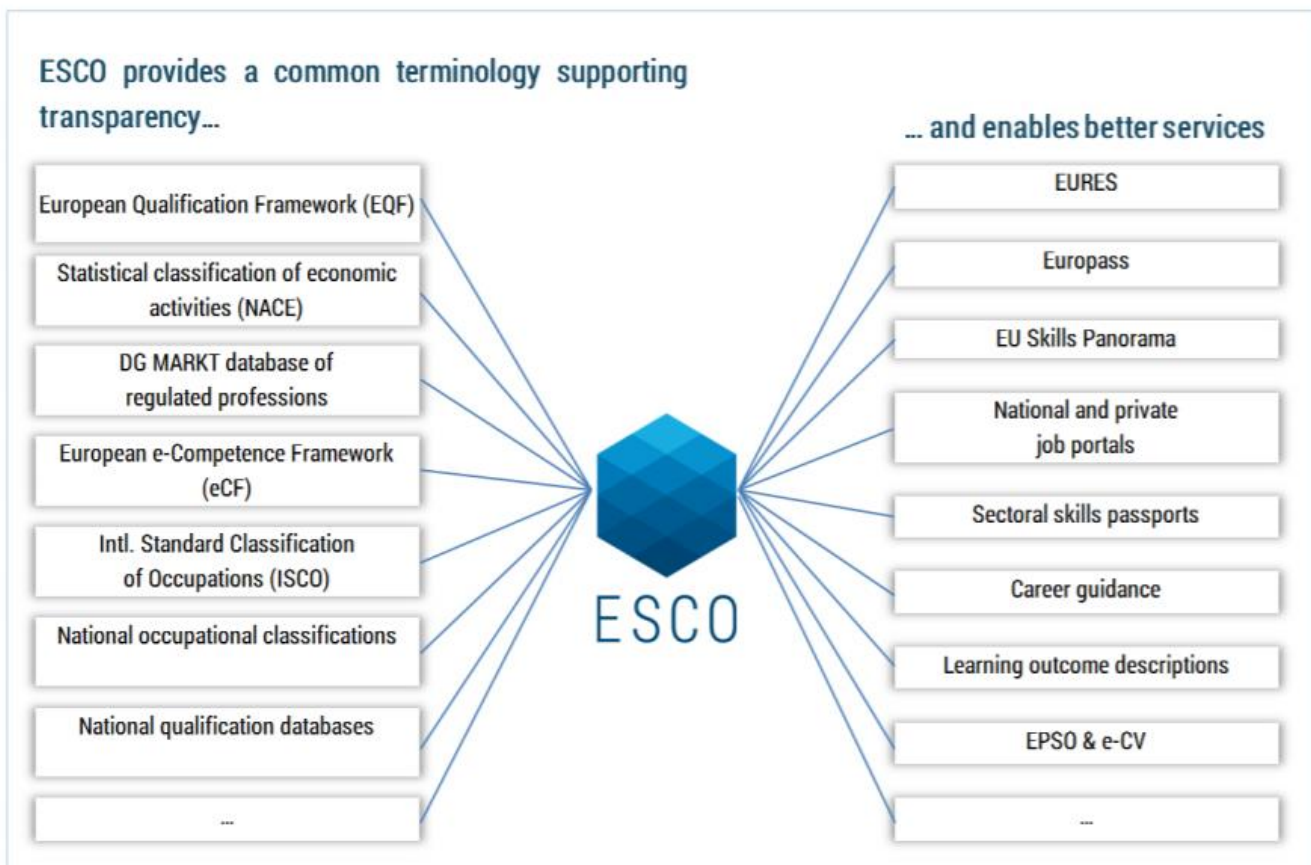

Fig. 1: ESCO provides a common terminology supporting transparency and enables better services 
The ESCO skills pillar distinguishes between

i) skill/competence ideas, and

ii) knowledge concepts by pointing to the type of skill.

In real sense, there is no difference between competences and skills. Each of these ideas appears under one preferred term and any one of non-preferred terms and concealed terms in each of the ESCO languages.

It also provides the details of the concept by means of description, definition and scope note. However, skills pillar of ESCO does not have a hierarchical structure in full sense rather it is planned in four different ways:

- Through their relations with professions, i.e. by using professional profiles as entry point;

- Regarding the transversal knowledge, skills and competences by means of a skills hierarchy;

- The relationships shared by knowledge, competences and skills indicate the relevance of these points to others (to be more specific, for skill contextualisation);

- Through the medium of operational collections that allow to choose subsets of the skills pillar.(ESCO Board, 2017)

\subsubsection{Access ESCO}

ESCO follows Linked Data initiative and provides an API to query ESCO in semantic manner. (le Vrang et. al, 2014)

The Linked Open Data method helps users to:

- easily combine data with their existing IT systems;

- link to other sources;

- ensure that the data is well maintained and quality-assured before publication;

- ensure that updating the information does not lead to high administrative expenditure. 


\subsubsection{How could ESCO be used?}

There are many promising approaches in which a multilingual classification and standardised European terminology covering skills, abilities, qualifications and professions could be applied. In general, it will accelerate and assist communication and promote more systematic links and comparability between sectors, institutions and member countries. It will help supply and demand on the labour market to avoid being mismatched, activate more accurate and precise skills and professional prediction and boost the quality and consistency of instructional information. In fact, it will make it easier for people, public employment services, instruction providers and employers to look for the relevance of learning outcomes in national qualifications to activities and professions and to application of the common language. Practical instances of uses that could be supported by ESCO are as follows:

- Candidates can use it to define their skill set while writing a CV that can then be easily used for a range of automatic matching purposes;

- Employers can use it to mention and describe a set of skills and competences required while developing a job description to be advertised with public or other employment services;

- Learners can use it to develop personal skill profiles and to record their learning outcomes;

- Bodies developing and/or awarding qualifications can use it to express learning outcomes in more functional taxonomies;

- Educational and training institutions can use it to improve the quality of planning, curriculum and materials related to emerging skill needs and to facilitate the recognition of foreign qualifications;

- HR managers and guidance providers can apply it to enhance planning and enrich aptitude/ability tests, skills and interest inventories/devices;

- ESCO will provide for a closer matching of European candidates to jobs through the platform known as 'EURES - The European Job Mobility Portal'; 
- New initiatives with a European dimension such as a European Skills Passport, self-assessment and career guidance tools could be supported. (ESCO Board, 2017) 


\section{EXPERIMENT RESULT AND ANALYSIS}

\subsection{Modelling expected changes}

The numerical results of the total domestic output (employment intensities) and labour requirement predictions for Hungary (2008) are presented in this analysis. As follows Table - 1 NACE Rev. 2 industry classification has been used in this analysis. NACE is the "statistical classification of economic activities in the European Community" which imposes the job grouping unvaryingly within all the member states of European Union. NACE Rev. 2 reveals the procedural progresses and organizational changes of the economy, empowering the renovation of the communal statistics and subsidizing, through more comparable and relevant data at both public and national level.

The mentioned method of assessment of the input-output table and the development of the labour valuation was used for a selected year 2008 on the data for the Hungarian economy. 2009 data for the final domestic demand used here for the second year labour approximation. Another year's data can be used here in same format. The outcomes in the article are presented in accumulated form on the level of the sections of this sorting for sake of clarity. In the result graph (Fig. 10.) all segments are expressed using alphabets (Ahmed, F, 2016). 


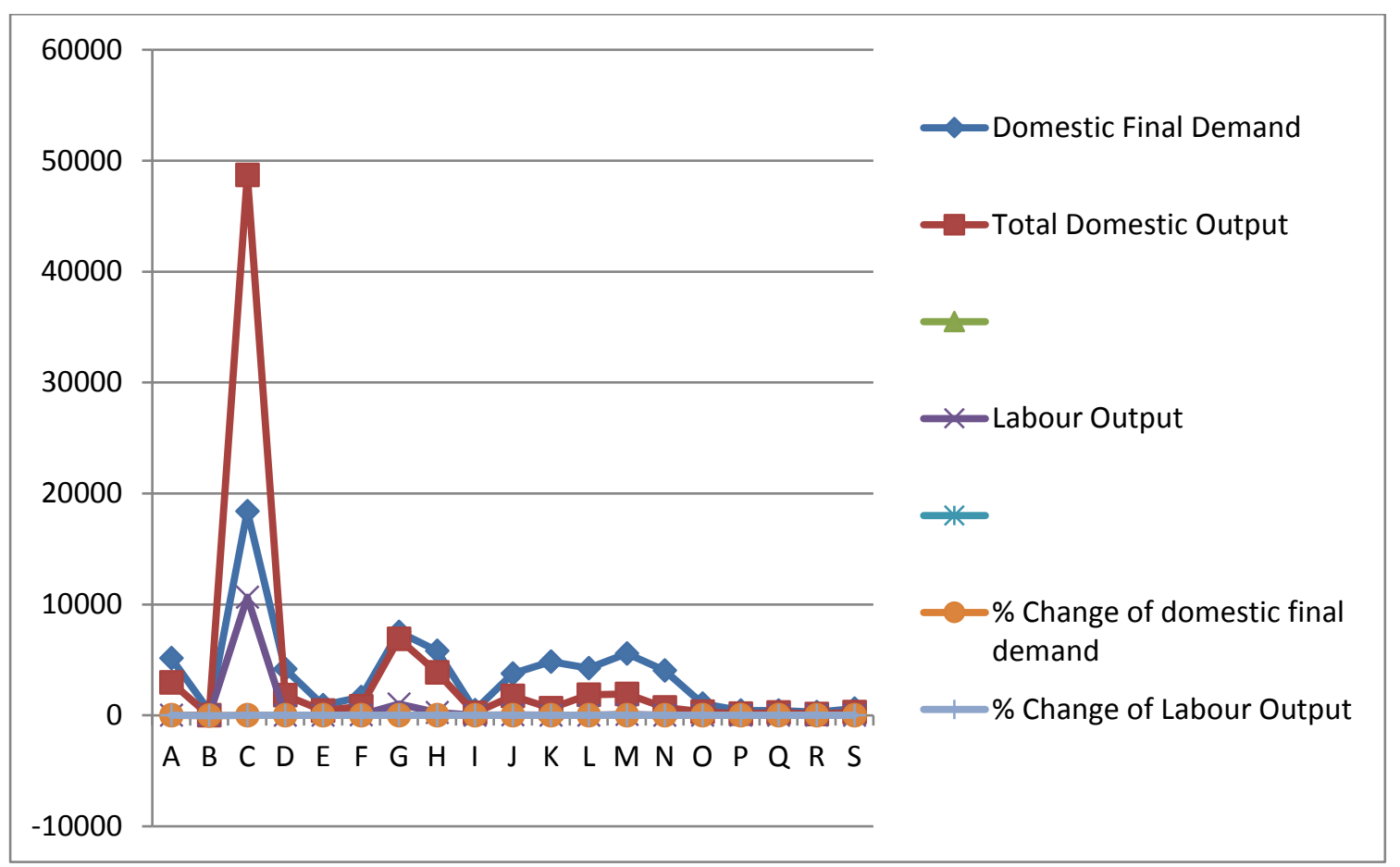

Figure 10 Shows the number of workforces on production (thousand Euros) of the products broken down by the sections of the industries classification the NACE Rev. 2, in thousand persons.

The Figure 10 clearly shows that the products of manufacturing industry (section C), wholesale and retail trade, repair of motor vehicles and motorcycles (section G) and real estate activities (section L) are most positive sectors for labour output in Hungary economy. It is steady with reality in Hungary. This graph shows clear decrease in the number of labour spent on the production of mining and mining (section B) as well as on accommodation and food service activities (section I). In association to the real output development it is clear that in case of water supply, sewerage, waste management and remediation (section E) the labour output decreased. In case of mining, both production and labour output decreased. In manufacturing production industry, labour output was increased quite significantly $(33 \%)$.

The gradually development is also recorded for publishing, audio-visual and broadcasting activities, telecommunications and other information services (section J) and financial and insurance activities (section K). In legal, accounting, management, architecture, engineering, technical testing and analysis activities, scientific research and development, other professional, scientific and technical activities (section M), labour output drop (zero) is evident in this selected year, 
another two sectors electricity, gas, steam and air-conditioning supply (section D) and transportation and storage (section $\mathrm{H}$ ) workforce development are near to zero.

Increase in labour output is obvious in case of Agriculture, forestry and fishing (section A) and Construction (section F) when the number of labour output increased and current increase in product was not significant. Steady in terms of labour output is clear in cases of the Education (section P) and the Human health services, Residential care and social work activities (section Q) and Arts, entertainment and recreation (section R). Public administration and defence, compulsory social security (section $\mathrm{O}$ ) is also under minor change groups. The other services (section $\mathrm{S}$ ) recorded the increase in total production is not a significant change in labour output.

For the changing in input-output coefficient we found a sensitivity analysis result. Coefficient changes in one sector affects all sectors significantly. Table- 2 shows the input-output coefficient change in Agriculture, forestry and fishing (section A) sector and Fig. 11 shows the significant change of labour output in different sectors ${ }^{11}$.

\begin{tabular}{|l|l|l|l|l|}
\hline $0 \%$ & $1 \%$ & $2 \%$ & $3 \%$ & $4 \%$ \\
\hline 0.378691 & 0.382478 & 0.386265 & 0.390052 & 0.393839 \\
\hline
\end{tabular}

Table 7 Occupation coefficient changes in percentages

11 This result also published on my other conference paper: ECIC 2016 - 8th European Conference on Intellectual Capital. 


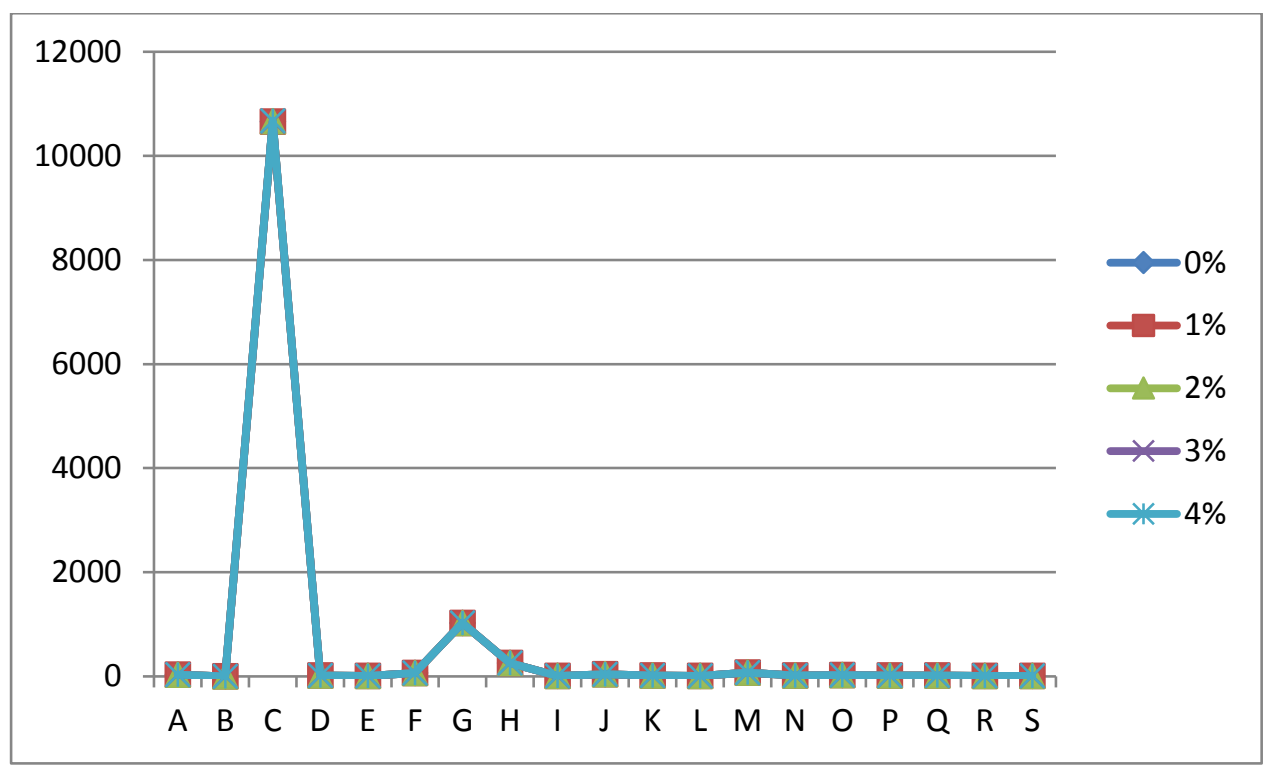

Figure 11 Changes in labour output

Fig. 11. shows that changing in one sector of input-output coefficient, labour output changes of Manufacturing (section $\mathrm{C}$ ) and Wholesale and retail trade, repair of motor vehicles and motorcycles (section G) sectors are dramatically. Due to the decreasing of production, the percentage change of labour output shows in negative direction.

The coefficient tables (Table-6) have been made after downloading as an excel file and did some changes manually from the input-output table data of EUROSTAT dataset. We can summarize the occupation result by following way: Suppose the industry 1 is an electric vehicle manufacturing industry. (Here I am using the data from EUROSTAT table. In this experiment it is not a real scenario). International Standard Classification of Occupations 2008 (ISCO-08) provides occupational information obtained by statistical censuses and surveys. A list of nine occupations is used here for an example demonstration.

The occupation input coefficient (Fig. 12.) table can be found from basic input output table. The total values of input coefficients including the gross value added serving in each sector is as defined. This series of calculations is made for Basic Transaction Tables for 19 sectors in the 2008 Input-Output Tables. 


\begin{tabular}{|c|c|c|c|c|c|c|}
\hline & & & V & V4 & v5 & \\
\hline$[1]$, & 0.000958578 & 0.000000000 & $0.00 \mathrm{e}+00$ & 0.000000000 & 0.000000000 & 0.00000000 \\
\hline & 0.000000000 & 0.000623739 & $0.00 \mathrm{e}+00$ & 0.000000000 & 0.000000000 & 0.00000000 \\
\hline & 0.000000000 & 0.000000000 & $4.89 e-05$ & 0.000000000 & 0.000000000 & 0.00000000 \\
\hline & 0.000000000 & 0.000000000 & $0.00 \mathrm{e}+00$ & 0.009993027 & 0.000000000 & 00000000 \\
\hline & 0.000000000 & 0.000000000 & $0.00 \mathrm{e}+00$ & 0.000000000 & 0.004942977 & 00000000 \\
\hline & 0.000000000 & 0.000000000 & $0.00 \mathrm{e}+00$ & 0.000000000 & 0.000000000 & 49867 \\
\hline & 0.000000000 & 0.000000000 & $0.00 \mathrm{e}+00$ & 0.000000000 & 0.000000000 & 0.00 \\
\hline & 0.000000000 & 0.000000000 & $0.00 \mathrm{e}+00$ & 0.000000000 & 0.000000000 & 0.00000000 \\
\hline & 0.000000000 & 0.000000000 & $0.00 \mathrm{e}+00$ & 0.000000000 & 0.000000000 & 0.00000000 \\
\hline & & & & & & \\
\hline
\end{tabular}

Figure 12 Occupation input coefficient

Occupation $=[$ Occupation coefficient matrix $] *[$ Total Domestic Product $]$

A programming script has been generated to find the result.

Occupation-wise number of labour (thousand) in each sector:

\begin{tabular}{rr}
\hline & $\mathrm{v} 1$ \\
{$[1]$,} & 29.808566755 \\
{$[2]$,} & 0.007002218 \\
{$[3]$,} & 2.382274348 \\
{$[4]$,} & 18.349921905 \\
{$[5]$,} & 2.132104911 \\
{$[6]$,} & 6.800017379 \\
{$[7]$,} & 33.820486622 \\
{$[8]$,} & 7.617567370 \\
{$[9]$,} & 2.534336328 \\
{$[10]$,} & 5.498275370 \\
{$[11]$,} & 3.397281304 \\
{$[12]$,} & 5.660738482 \\
{$[13]$,} & 9.282956832 \\
{$[14]$,} & 5.887848772 \\
{$[15]$,} & 3.313814211 \\
{$[16]$,} & 0.000000000 \\
{$[17]$,} & 0.118193374 \\
{$[18]$,} & 0.000000000 \\
{$[19]$,} & 0.000000000 \\
$>$ &
\end{tabular}

Figure 13 Sector-wise number of labour for manager

If we assume this result for a particular industry like Electrical Vehicle industry, we found number of position in thousand for one occupation like the position of manager. The negative value shows that the position is in minus value according to the economic, technical or production condition of this job sector. These negative values can be resulted from the matrix calculations of internet data. It must be considered to leave them from the analysis due to the fact, that it does not reflect the reality well. This dissertation focuses on presenting how this solution can support the 
investigation of research questions and not to support current decision making process with real data. The test of this solution can be proceeded with this data as well.

Now if we change the one coefficient value with some percentage. The changes of coefficient value depend on many economic parameters that are beyond the purpose of this paper.

Changing occupation coefficient for Sector 1 and Occupation 1 from 0.000958578 to $0.0009,0.0005$ and 0.0001 the result is as follows:

\begin{tabular}{|c|c|c|}
\hline $\begin{array}{l}\text { For Coefficient } \\
0.0009 \\
>01 \_ \text {change }\end{array}$ & $\begin{array}{l}\text { For Coefficient } \\
0.0005 \\
>01 \text { change }\end{array}$ & $\begin{array}{l}\text { For Coefficient } \\
0.0001 \\
>01 \text { _change }\end{array}$ \\
\hline $\begin{array}{rr}{[1,] \quad 9.6760088}\end{array}$ & $\begin{array}{rr}\mathrm{V} 1 \\
{[1,]} & 5.3755605\end{array}$ & $\begin{array}{rr} & \mathrm{V} 1 \\
{[1,]} & 1.0751121\end{array}$ \\
\hline
\end{tabular}

Figure 14 Coefficients

Result in graphical views (Fig.15.)

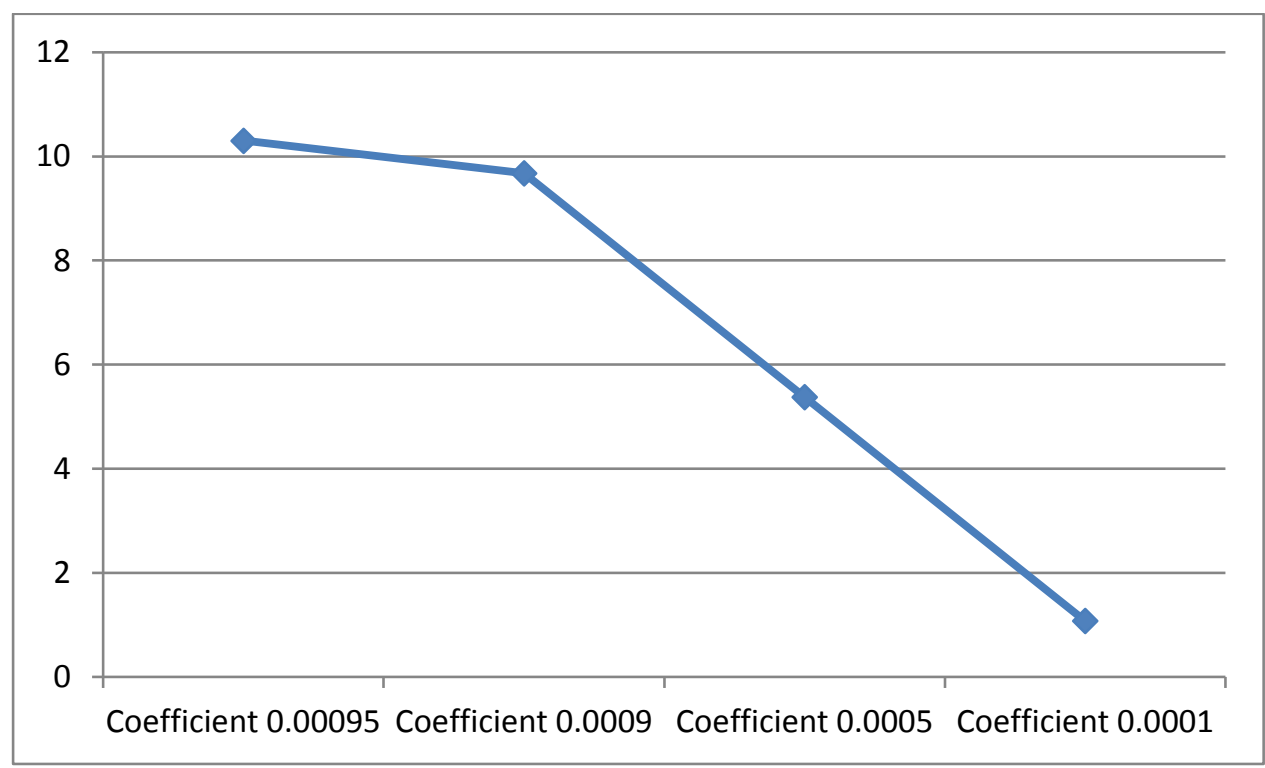

Figure 15 Thousand number of position change as follows the coefficient value

This result shows that the manager position is decreasing day by day by changing the coefficient value which comes from some economic factors. 
Therefore, by using this framework academies who know the economic condition of a country and by following the economic trends they can predict the future occupation and can prepare their curriculum for future.

\subsection{Analysis with business scenarios}

Business scenarios are to plan future activities depending on different technological, economical, demographical - factors. This application (program) is capable of absorbing these thoughts by transforming them into the changes of coefficients. Our goal is to investigate future occupational and competence structure. We can distinguish three types of business scenario influencing job structure:

1. Time horizon / preference selection

2. Growing economy due to the increasing FDI

3. Changes in productivity not taking effects on sectorial structure

4. Changes in technological environment taking effects on sectorial structure

\subsection{Time horizon / preference selection}

The next problem is to select the suitable time horizon. The lower limit will be the minimum time, during which any change is becoming 'visible' on the national accounts, become manifest statistically. Theoretically there is no upper limit, only limitation how far we can see in the future to keep the possible scenarios still realistic. If we consider the 'lead time' of a typical higher education institution, the most appropriate time horizon is between 3-5 years.

\subsubsection{The growing economy (Foreign Direct Investment)}


In general economy may grow due to several reasons, increasing productivity, growing export, growing domestic demand, large volume of international aid (e.g EU Structural and Cohesion Funds), etc. A special case is the Foreign Direct Investment, the investor is not selling or buying something but creates production sites, jobs, and the economic growth is based both on the direct investment and the additional gross domestic products due to the accelerator effect ${ }^{12}$. I/O model is suitable to reflect both (direct and indirect) effect. In the first scenario we assume, the recently experienced fast development of electric car manufacturing will effect on the volume and structure of FDI. Retail sale of fossil energy is expected decreasing, energy sector as a whole need to be restructured, more investments, and technological development is needed, while the agro-based renewable energy production will decrease.

As a result, the inter-relations of the sectors will change, the overall domestic output will be increased. As one of the consequence, the labour-part of the GDP will change as well, both in terms of quantity and occupation structure, hence the change requests different skill-set and follows the changes in occupational structure (for the sake of simplicity linearity is assumed, which results some bias).

\subsubsection{Changing the requested labour force (productivity, unchanged structure)}

In the EU and G20 countries a sound increase of productivity is monitored ${ }^{13}$. The annual average is around $20 \%$, with very big differences among the countries. The largest improvement happened in Ireland and 135\% productivity index is expected by $2018(2010=100)$. From the point of occupational structure and demanded skill set point of view we may model the quantitative changes through the labour

\footnotetext{
${ }^{12}$ Foreign Direct Investment Statistics: Data, Analysis and Forecasts - OECD, http://www.oecd.org/corporate/mne/statistics.htm/, last accessed 2017/08/17

1. ${ }^{13}$ Level of GDP per capita and productivity, http://stats.oecd.org/Index.aspx?DataSetCode=PDB_LV, last accessed 2017/08/18
} 
coefficients. The question is, in what extent will follow the occupational structure the increasing productivity (the assumption is the less-skilled workers' ratio will decrease).

\subsubsection{Changing the requested labour force (technology, different structure)}

Coefficient Values Total Domestic Product $\quad$ Total Labour $\quad$ Occupation Based Labour $\quad$ Plot

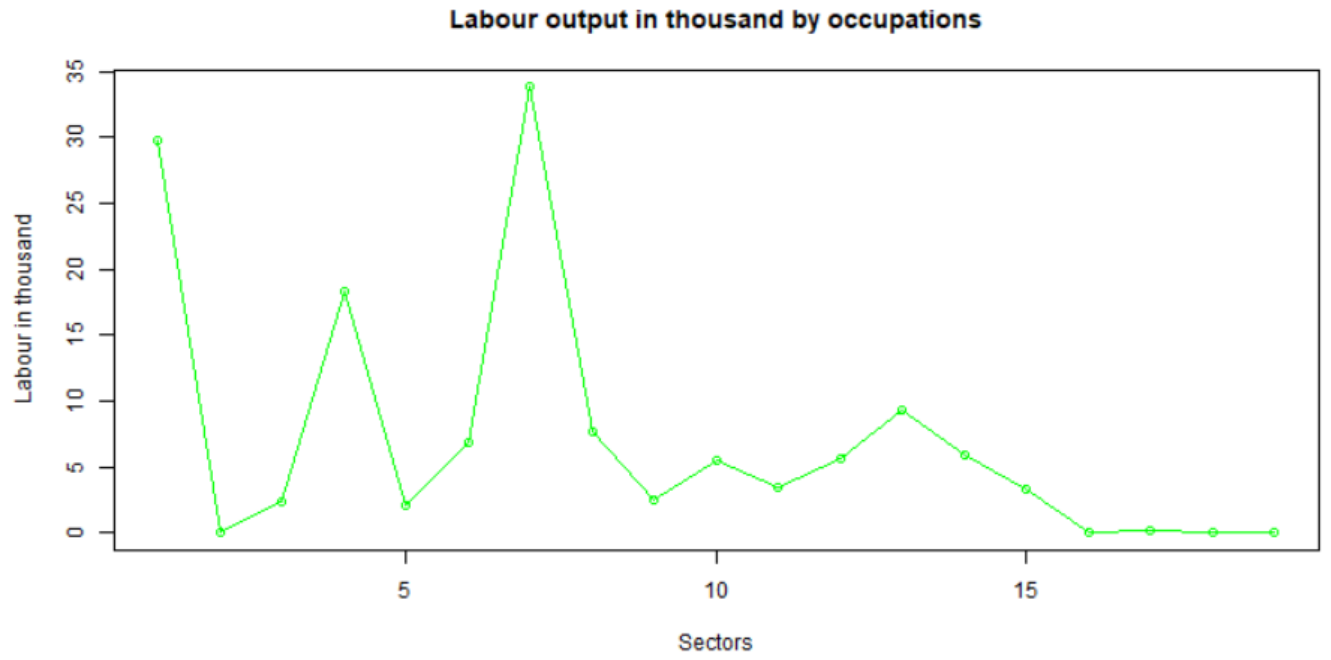

Figure 16 Number and distribution of managerial position by sectors

A business scenario reflecting the influence of growing number of electric car was used to present the working of this system. Fig. 16. shows the number and distribution of the managerial positions by sectors. The expected changes in terms growth of output, improving productivity and creating new (skilled) jobs will change the localisation of the managerial positions (Fig. 17.). The result is almost double the demand for skilled workers, and the relative growth is bigger in the productive sectors (first economy) than in the second and third. 


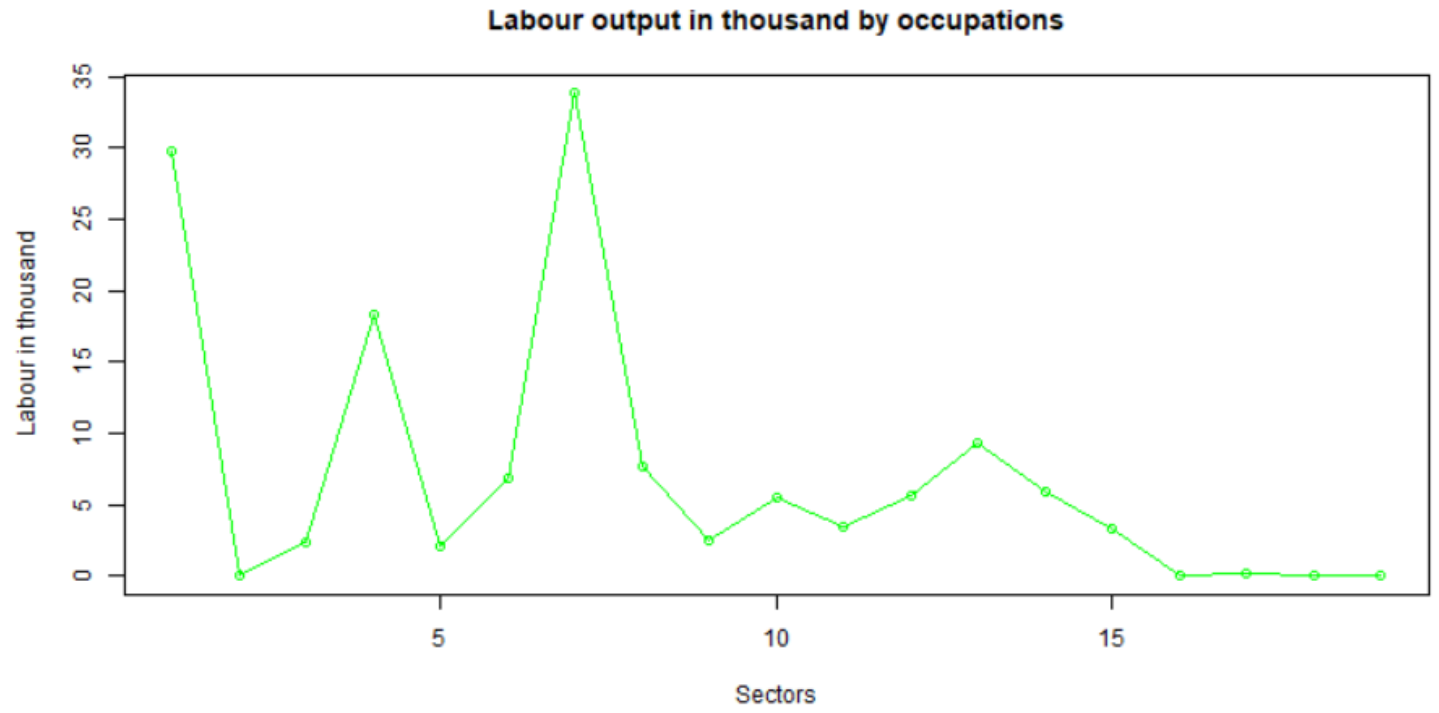

Figure 17 Number and distribution of managerial position by sectors in 5 years

Nowadays ESCO collected the main managerial aspect like "plan, organize, coordinate, control and direct the work done by others." The figures present that the role of manager will increase in almost all sectors, hence we can state that these competence will be important in the future. But there are managerial competences specialized in a given sector e.g. monitoring fields and managing agricultural staff by a crop production manager or monitoring technological trends and managing contracts by an ICT production manager. The more labour intensive a sector, the more requiring its specific competences are.

The selected most important competences can be compared with the competences provided by a training program via Smart+ system. This gives very clear indication to the education sector how and in which direction develop their portfolio.

To execute deeper analysis along the hierarchy of ISCO occupations, the distributions of these occupations per main group are needed. If publishing governmental data on Internet will be a best practice, it solves this problem. 


\subsubsection{Other internal and external factors}

Other internal and external factors that can affect the business scenario of employment industries are as follows:

Internal and External Factors of Compensation

Any benefit awarded to the employees in return for the work they do for the organization is called Compensation. This benefit can be both monetary and nonmonetary in nature. In its most common form, salaries and wages are given as compensation to the employees. The internal and external factors influencing compensation are as follows.

Internal Factors

The factors that are inherent within the organization are the internal factors of compensation. They are:

\section{Ability of Paying}

An employee's compensation greatly depends on the ability of the organization to pay the employee. Large organizations, in general, are able to offer higher payment to the employees whereas small organizations often cannot afford to maintain employee compensation at the level of large organizations.

\section{Business Strategy}

Business strategy of a company also affects employee compensation. The organizations seeking skilled employees are willing to offer higher compensation to their employees. On the other hand, well-established companies who wishes to move forward with existing employees will offer comparatively lower compensation to its employees. 
Employees generally get different levels of compensation based on their performance appraisal. The organization would be willing to offer better compensation to its high performers.

Job Evaluation

For different roles and responsibilities within the same organisation, different levels of compensation are offered.

\section{Employee}

The ways in which an employee herself can shape his compensation are:

1. Performance: Employees performing better in an organization can negotiate for better payment in return for high performance.

2. Experience: In general, experienced employees can contribute more to the organization than their inexperienced counterparts and are more likely to get better payment. Also, experience within the same organization is considered an asset and therefore long term employees are compensated better.

\section{Employee Potential}

An organization generally offers better payment to the employee or prospective employee in whom they see potential to greatly contribute to the company in future.

\section{External Factors}

Factors that are not within the purview of the organization itself but influences the employee compensation directly or indirectly are the the external factors of compensation.

\section{Labour Market}

The labor market condition, i.e. the demand and supply of labor affects an employee's compensation. The general economic principle dictates that in a market where demand is greater than the supply of labor, employees or workers get higher salaries and wages, and vice versa. 
The compensation is often based on the historical level of salaries and wages handed out to employees in a particular industry. This also explains the different level of compensation for the same industry in different countries and regions.

\section{Productivity}

Efficient workers are expected to get better compensation. Competitive industries focus on efficiency of their workers and often initiate an result oriented efficiency based pay-scale. Pragmatic organizations also bring about changes, such as, better machinery, process re-engineering, management overhaul, etc. to increase productivity of their workers and reward them with higher compensation in return for their increased productivity.

\section{Living Cost}

Compensation for the same work tends to be higher in the regions or countries where cost of living is higher. Cost of living index, or, general price index greatly determines the compensation level for any job in a particular geographic region.

\section{Labour Unions}

The influence of Labour Unions in determining the compensation for different jobs cannot be denied. It is often observed that compensation for similar jobs tend to be higher in regions or countries where labour unions are legalized and strongly organized. On the other hand, organizations in non-unionized industries enjoy freedom and flexibility in setting up offering compensation for employees.

\section{Laws and regulations}

International, national and local laws and regulations often compel organization to offer minimum wages to its employees. These laws also ensure a stipulated benefit, gratuity, provisions for health and medical emergencies, paid leaves etc. that constitute the compensation in the broader sense. 
These internal and external factors determine the compensation an employee is expected to receive in her job as a reward for the skills, time, and effort he/she puts into the work. (Business Gargons-HR: Factors affecting employee compensation)

\subsection{ReSUIT of selected business scenario: E-car manufacturing}

The new technological phenomenon, the fast growing ratio of electric cars among the vehicles. Norway e.g. expects electric or hybrid cars make up half of new vehicle registrations in 2017 (Ecar, 2017) E-car manufacturing needs significantly less skilled jobs in the traditional machinery sectors, although less but better trained and skilled workers in the designer and constructing parts of car manufacturing. These changes will lead to the changes in the occupational structure (Hamilton, J. 2012).

On the other hand the forecasted technology breakthrough will affect not only the manufacturing sector but significant changes are expected in the energy sector, too. Electric Vehicles (EVs) promise technology for reducing the environmental burden of road transport. Other energy types like renewable energy production provides the largest market swing over time: from $19 \%$ of production in 2010,32\% is expected in 2020 and will continuously grows up to $50 \%$ by 2050 (van Essen and Kaupmann, 2011).

Technology plays a vital role for changing labour market trends. Several industry studies in equal extent say that fully autonomous vehicles are to be commercially available before 2020. In 2030, the share of electrified vehicles could range from 10 percent to 50 percent of new-vehicle sales.

As a consequence the technological impact on the demand side of labour market implies structural changes of required competencies. Educational institutes need time to change their educational portfolio due to the lead time of formal education. A system which is capable to predict the future occupational structure and conclude to the required competencies can facilitate decision making processes both in the educational institutes and in the world of labour. 
The electric vehicle industry could grow in a better pace this will help in job creation in the related occupations. This industry is as same as it in all types of automobiles. Some non-traditional jobs, and workers' skill sets and also must evolve and keep the fast pace of development in electric vehicle industry. Here it is described some careers related to electric vehicles industry mainly the electric vehicle industry and its growth. After that an application scenario has been introduce to show number of labours requirement for a particular industry like e-car manufacturing.

\section{The electric vehicle industry evaluation}

Since the invention of automobile the electric vehicles are there in one form or another. In the early 1900s electric vehicle are sold more than the gasoline-powered vehicles. But in the 20th century it lost its market due to availability of cheap fuel and improvements to the gasoline engines. In recent time with advancement of technology electric vehicle industry is once more coming in the scene. According to the U.S. Department of Energy's National Renewable Energy Laboratory, U.S. sales of electric cars increased from near zero in 1999 to about 250,000 in 2010. Sales of electric vehicle will increase due to the reason of improvement in the technology and wide acceptance among the customers. An August 2009 study by the Center for Entrepreneurship and Technology at the University of California, Berkeley, projected that by 2030; electric cars will make up 64 percent of sales of all light vehicles (passenger cars, vans, pickup trucks, and sport utility vehicles). For environmental benefits customers are buying electric vehicle.

Electric vehicle pollutes fewer environments as its use electricity to run the engine and in this way it also helps in reducing use of petroleum. As the price of gasoline is constantly increasing day by day, the demand of electric vehicle are going more in high pace. This all factors are showing future demand for electric vehicle. All-round infrastructure developments are needed to run this kind of electric vehicle in the road. Some types of electric vehicles rely on charging stations for power, and most charging stations are installed in the homes. Very few public charging stations are installed all round the country. According to the National Renewable Energy Laboratory, 11 states had no public charging stations as of June 2011, and 16 states had 10 or fewer. 
In many ways electric vehicle are similar to the gasoline powered vehicles. The whole systems electric vehicle works in a lithium-ion battery and electric motor and gasoline powered vehicles rely solely on a gasoline-powered internal-combustion engine.

Electric vehicle have many types such as hybrids, plug-in hybrids, and all-electric vehicles. Hybrids and plug-in hybrids both run with electricity and gasoline. Allelectric vehicles use only batteries and need specially charging stations. Plug in hybrids are improvised vehicles which have dual power system of gasoline and battery. In case the battery dies out the vehicle can use gasoline till it get the charging station to charge its battery units! According to the Center for Entrepreneurship and Technology's 2009 study Electric-vehicle manufacturing is expected to create more jobs to the worker and maintainer of lithium-ion batteries. The study also mentioned that by 2030 the electric vehicle industry will drive a net employment gain of 130,000 to 350,000 U.S. jobs. The electric vehicle industry will create new occupations in the job market.

The U.S. Bureau of Labor Statistics (BLS) does not have any information regarding employment in the electric vehicle industry. However, BLS recently released data from its Green Goods and Services survey, which measures the number of green jobs in several industries related to electric vehicles. The survey shows those 5,920 green jobs in battery manufacturing, 9,700 green jobs in motor vehicle manufacturing, 18,850 green jobs in motor vehicle parts manufacturing, and 8,450 green jobs in automotive repair and maintenance.

Hybrid and electric vehicles are produced and serviced by major four industries which are giving lots of jobs shown by the survey. With this kind of data we cannot determine exactly how many of the jobs relate only to these vehicles.

\section{Driving change: Electric vehicle jobs}

From the scientists and engineers to the sales personnel many workers are related with the electric vehicle industry. The scientists and engineers help to research and 
develop idea. Whereas sales workers who explain the advantages of electric cars and trucks to the customers.

- Occupations in scientific research: Scientists are working for the development of electric vehicles and also have a focus on improving battery technology. For example long lasting battery units for plug-in and all-electric vehicles. Models and well design than the gasoline-powered vehicles. They are also working with the of batteries hybrid vehicles so that they consume less fuel. Advanced batteries unit will use less electricity and use fossil fuels. Offices and laboratories are place where they work specially. There are two types of scientists who help design electric vehicles, they are

a) Chemists: They use the knowledge of chemists to develop new and advanced batteries unity for electric cars.

b) Material scientists: They use the structured based study to develop new and advanced batteries unity for electric cars.

- Occupations in engineering: Design and development of electric automobile technology is done by engineering. They team up with scientists, and industrial production managers to make new processes or devices for manufacturing electric vehicles or renovating the existing ones. They apply principles of science and mathematics to develop economical solutions to technical problems. Many engineers produce designs for new products (Levy \& Murnane, 2012).

An application scenario for labour requirements of an industry using different coefficient changes:

R-Shiny (shiny.rstudio.com) based application used here for graphical viewing: 
Matching future job requirements with educational portfolio

\begin{tabular}{|c|c|c|c|c|c|c|c|c|c|c|c|c|c|c|c|c|c|c|c|c|}
\hline \multirow{2}{*}{\multicolumn{2}{|c|}{ Select Coefficient Table }} & & ficient Vat & & Total Dor & mestic Pro & oduct & Total L L & abour & Occupe & ation Base & ed Labou & Pid & & & & & & & \\
\hline & & & A & B & c & D & E & $\mathbf{F}$ & G & $\mathrm{H}$ & 10 & $J$ & $\mathrm{~K}$ & L: & m & $\mathrm{N}$ & 0 & $\mathbf{P}$ & Q: & $\mathbf{R}$ \\
\hline Input & - & A & 0.379 & 0.002 & 0.046 & 0.017 & 0.006 & 0.004 & 0.023 & 0.003 & 0.041 & 0.001 & 0.001 & 0.003 & 0.005 & 0.005 & 0.003 & 0.002 & 0.008 & 0.003 \\
\hline $\begin{array}{l}\text { Change the coefficient values between } \\
\text { Y-axis: }\end{array}$ & & B & 0.002 & 0.211 & 0.014 & 0.031 & 0.004 & 0.018 & 0.002 & 0.002 & 0.001 & 0 & 0 & 0.002 & 0.002 & 0.001 & 0.002 & 0.004 & 0.002 & 0.011 \\
\hline \multirow[t]{2}{*}{ Agriculture, forestry and fishing - A } & . & $\mathrm{c}$ & 0.378 & 0.308 & 0.726 & 0.44 & 0.248 & 0.525 & 0.224 & 0.334 & 0.47 & 0.188 & 0.064 & 0.203 & 0.166 & 0.202 & 0.125 & 0.165 & 0.439 & 0.013 \\
\hline & & D & 0.035 & 0.053 & 0.029 & 0.104 & 0.123 & 0.011 & 0.042 & 0.036 & 0.053 & 0.032 & 0.014 & 0.037 & 0.036 & 0.024 & 0.096 & 0.127 & 0.054 & 0.019 \\
\hline \multirow{2}{*}{$\begin{array}{l}\text { AND } \\
\text { x-axis: }\end{array}$} & & E & 0.005 & 0.009 & 0.007 & 0.007 & 0.174 & 0.006 & 0.011 & 0.003 & 0.012 & 0.003 & 0.003 & 0.011 & 0.005 & 0.01 & 0.026 & 0.025 & 0.021 & 0.041 \\
\hline & & $\mathrm{F}$ & 0.003 & 0.017 & 0.005 & 0.025 & 0.039 & 0.062 & 0.008 & 0.028 & 0.01 & 0.012 & 0.003 & 0.103 & 0.017 & 0.009 & 0.079 & 0.046 & 0.014 & 0.02 \\
\hline Manufacturing-c & • & G & 0.093 & 0.059 & 0.054 & 0.04 & 0.059 & 0.127 & 0.12 & 0.083 & 0.088 & 0.074 & 0.035 & 0.081 & 0.07 & 0.092 & 0.032 & 0.049 & 0.087 & 0.01 \\
\hline \multirow{2}{*}{ Insert new Coefficient Value } & & H & 0.037 & 0.152 & 0.028 & 0.106 & 0.056 & 0.055 & 0.127 & 0.255 & 0.031 & 0.045 & 0.042 & 0.026 & 0.04 & 0.097 & 0.124 & 0.044 & 0.025 & 0.149 \\
\hline & & 1 & 0 & 0.001 & 0.001 & 0.001 & 0.001 & 0.002 & 0.004 & 0.003 & 0.068 & 0.005 & 0.004 & 0.001 & 0.012 & 0.07 & 0.027 & 0.018 & 0.03 & 0.021 \\
\hline \multirow[t]{3}{*}{0.046} & 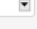 & J & 0.006 & 0.011 & 0.012 & 0.019 & 0.039 & 0.017 & 0.065 & 0.037 & 0.023 & 0.278 & 0.092 & 0.024 & 0.091 & 0.083 & 0.096 & 0.135 & 0.035 & 0.14 \\
\hline & & $\kappa$ & 0.024 & 0.023 & 0.008 & 0.021 & 0.031 & 0.033 & 0.053 & 0.036 & 0.031 & 0.032 & 0.458 & 0.27 & 0.064 & 0.048 & 0.08 & 0.02 & 0.015 & 0.059 \\
\hline & & L & 0.008 & 0.014 & 0.01 & 0.034 & 0.075 & 0.029 & 0.078 & 0.038 & 0.063 & 0.068 & 0.047 & 0.048 & 0.086 & 0.076 & 0.094 & 0.102 & 0.05 & 0.006 \\
\hline
\end{tabular}

Figure 18 Changing coefficient values between two industries.

After changing co-efficient a major changes have been occurred in total domestic product that are affecting the quantities of labour.

Matching future job requirements with educational portfolio

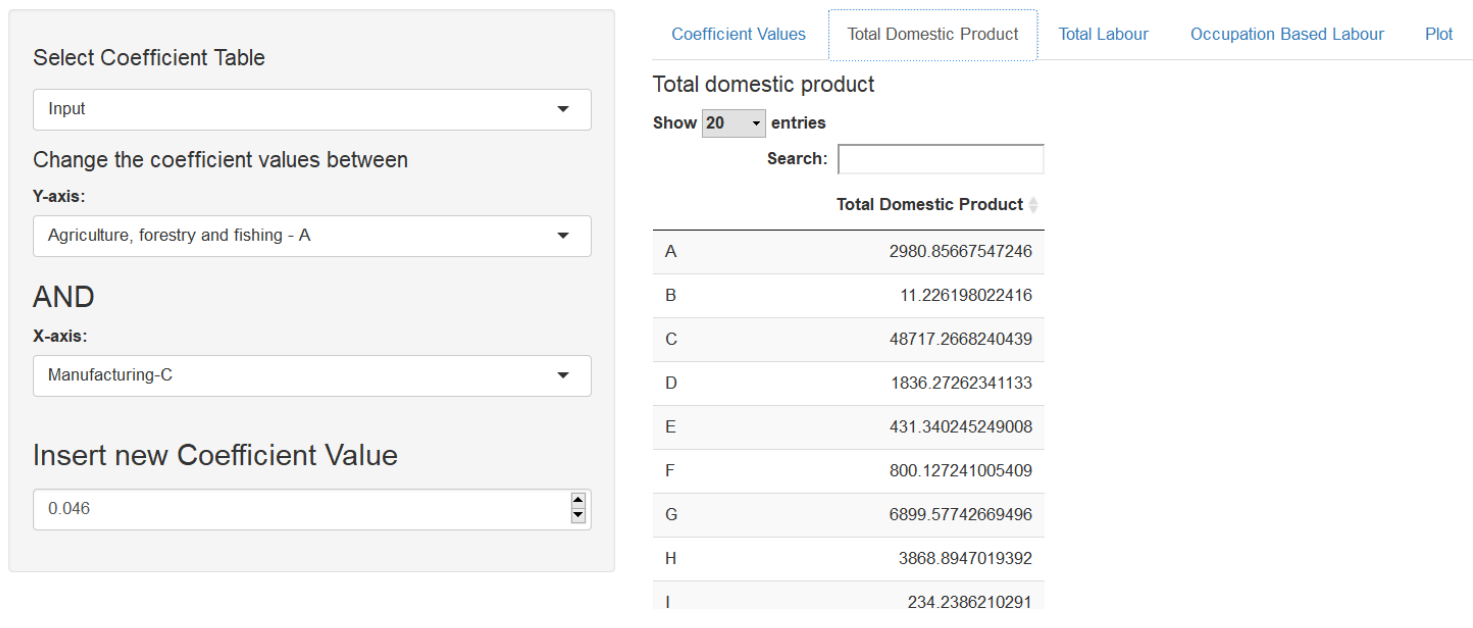

Figure 19 Total domestic product after changing coefficient. 
Matching future job requirements with educational portfolio

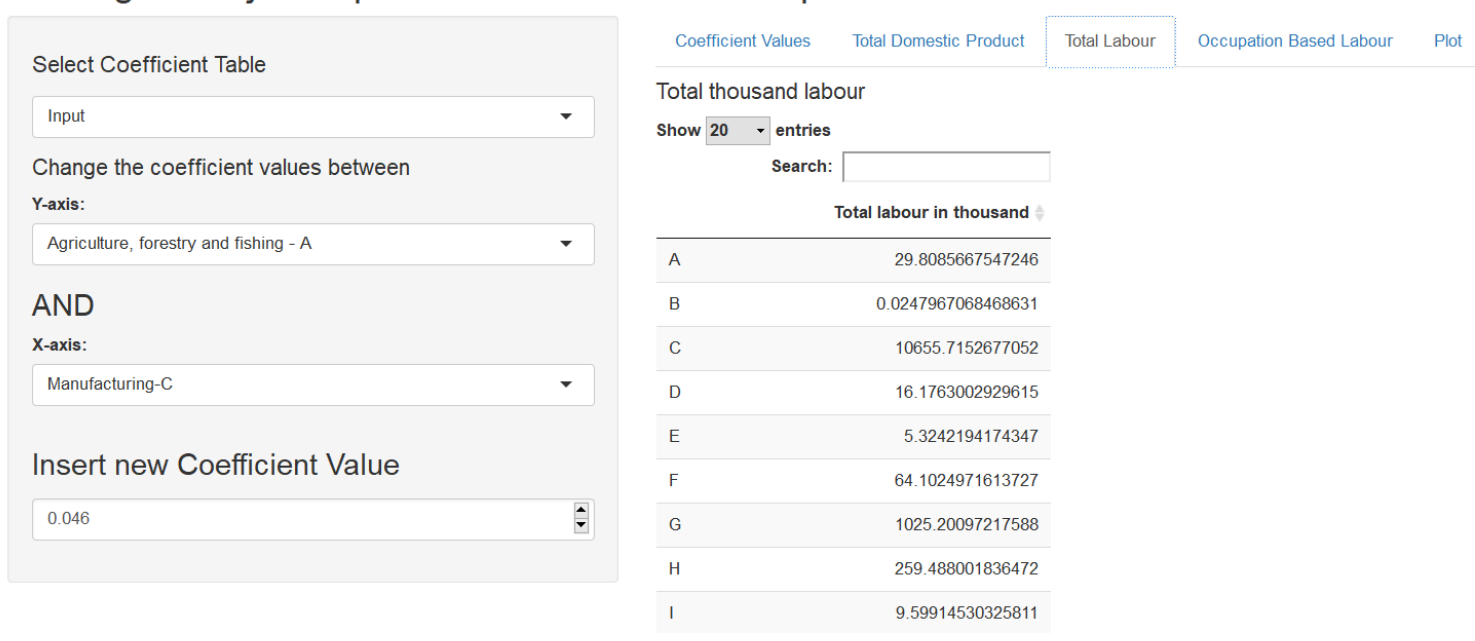

Figure 20 Total no of labour in thousand

Matching future job requirements with educational portfolio

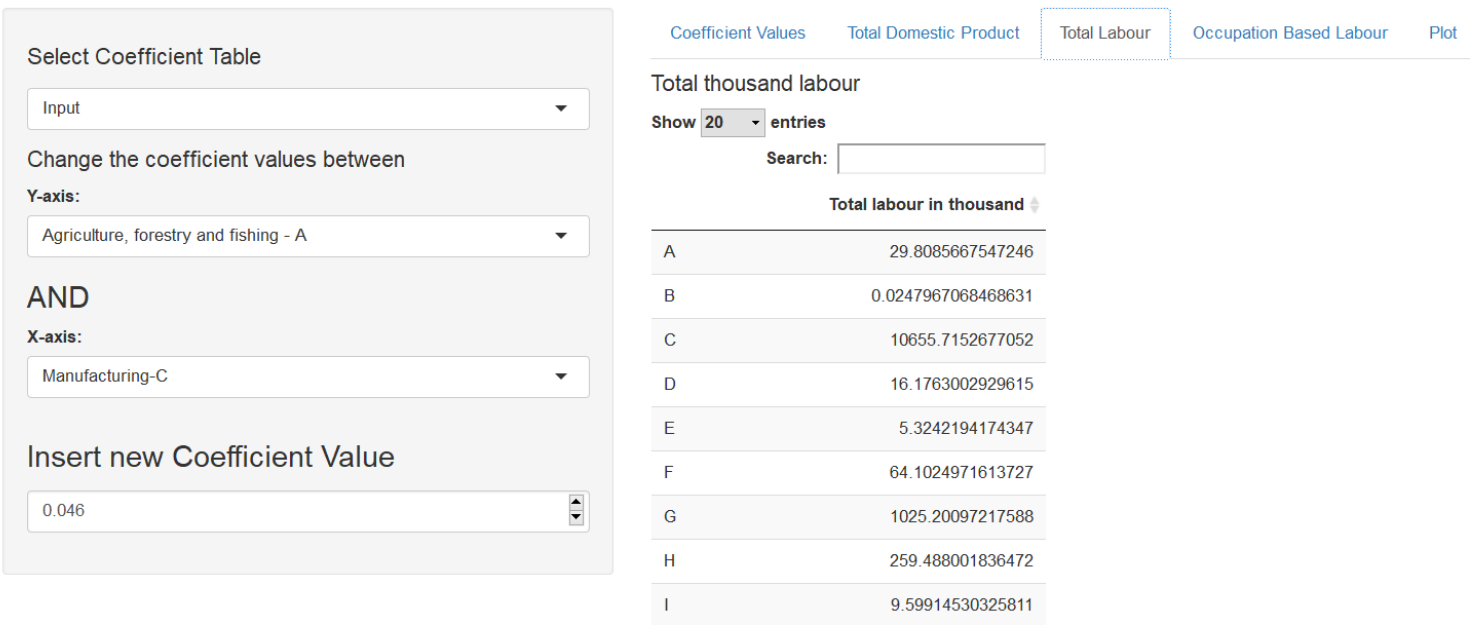

Figure 21 Occupation based labour like no of manager in a particular industry

Matching future job requirements with educational portfolio

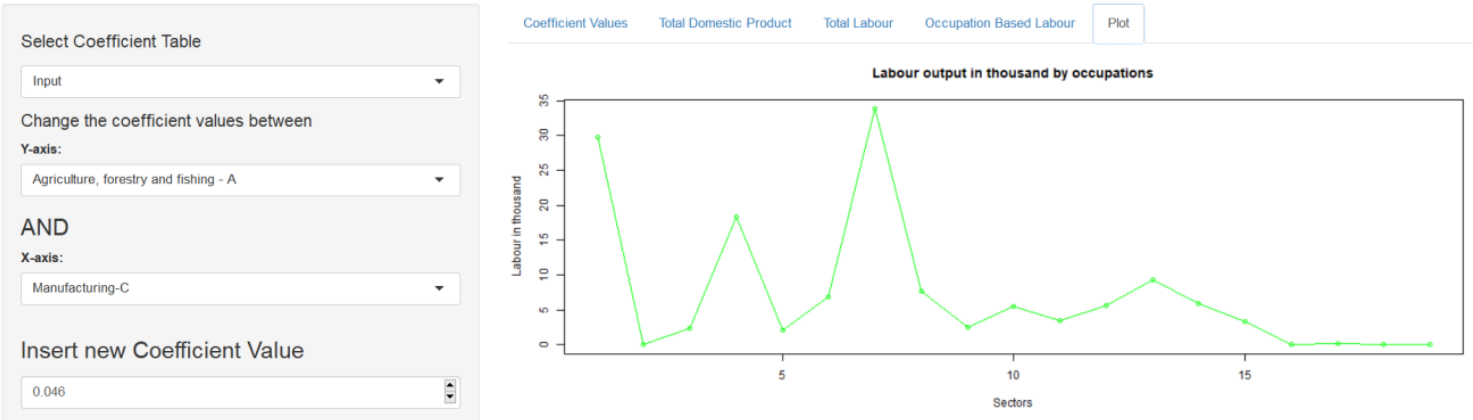

Figure 22 Plot shows labour changes after changing coefficient. 


\subsection{Changes in the importance of managerial competences}

Managers and supervisors are an essential in the success of a change initiative. In times of change, those who lead the teams impacted by change can be both a great associate and a real obstacle for change leaders. Managers are closest to the employees who must adopt the new processes and behaviours associated with a project or initiative. And in many cases the same project also impacts their own work. Getting managers and supervisors on board and prepared to support their teams through change is crucial. It does not fit into a doctoral research to collect all sector-specific managerial occupations and their competences. Hence the following ones were selected to illustrate how we can use the output of the system for analytical purposes. Sector wise and general competence sets for manager are given in ANNEXES 11.6 and ANNEXES 11.7

\begin{tabular}{|l|}
\hline Occupation \\
\hline crop production manager \\
\hline industrial production manager \\
\hline power plant manager \\
\hline water treatment plant manager \\
\hline construction quality managers \\
\hline sales account manager \\
\hline warehouse manager \\
\hline restaurant manager \\
\hline telecommunications manager \\
\hline insurance product manager \\
\hline real estate manager \\
\hline ICT research manager \\
\hline social services manager \\
\hline public housing manager \\
\hline head teacher \\
\hline elderly home manager \\
\hline recreational facilities manager \\
\hline quality services manager \\
\hline
\end{tabular}

Table 8 Sector-wise occupations

Tableau Software which can be considered as leader in the Gartner Magic Quadrant was used to present which consequences can be drawn from the output of the system. 
The following chart shows there are cross-competences required by several occupations in both cases (general or sector-specific competences).

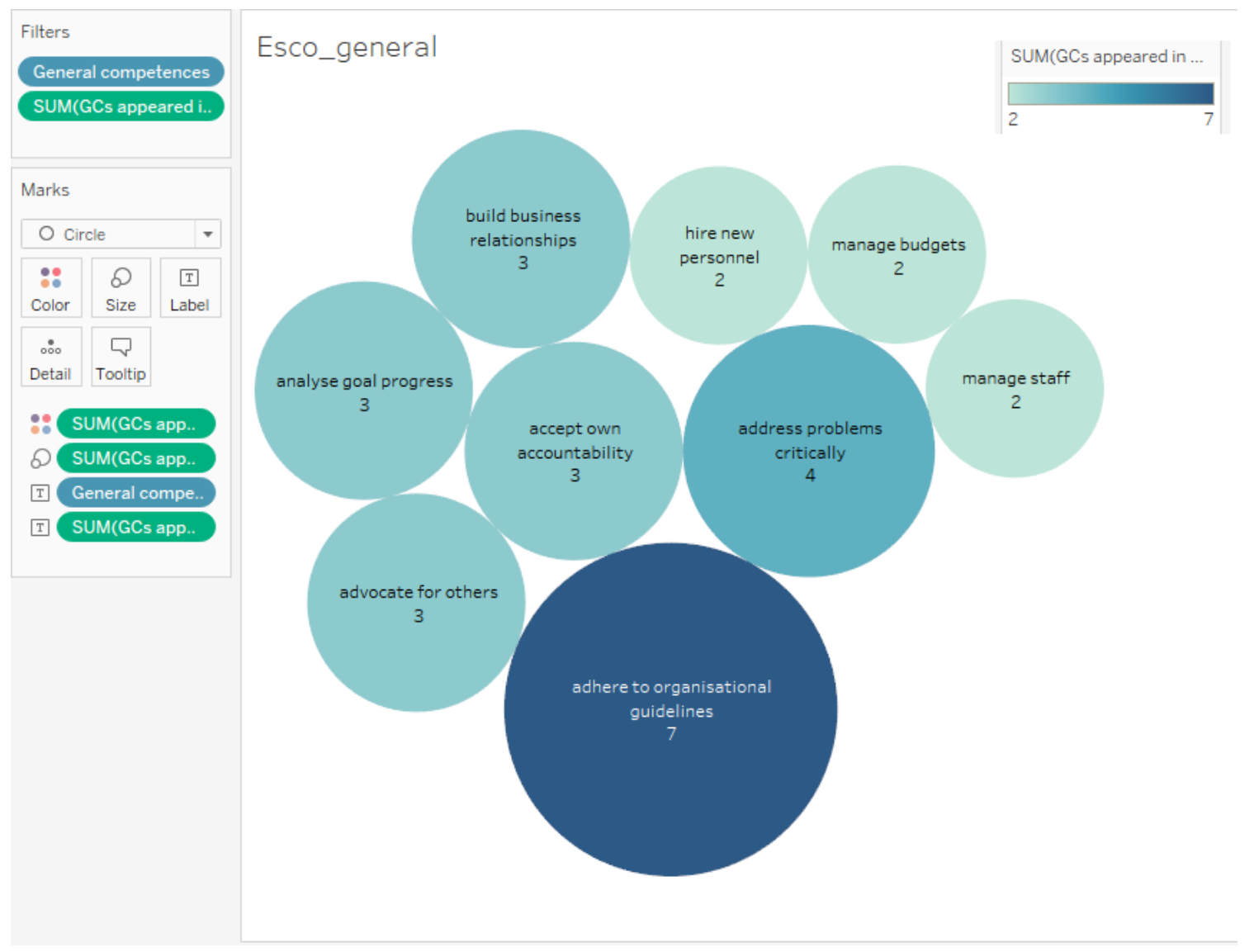

Figure 23 The distribution of general competences among the selected occupations

Different occupation comes with an occupational profile from ESCO portal. The profiles contain an explanation of the occupation in the form of description, scope note and definition. Additionally, they list the knowledge, skills and competences that experts considered relevant terminology for this occupation on a European scale. From many type of occupations one common occupation like manager in different levels for individual sector are used here. Competences of different type managers are picked up also from ESCO portal. Figure 24 shows the number of matching competences from counted different sectors.

The point is that the future importance of these competences is influenced by more than one occupational change. 


\subsubsection{General managerial competences}

From this chart and labour output (after changing coefficient values) from our previous application following Table 4:

\begin{tabular}{|c|c|c|c|}
\hline $\begin{array}{l}\text { Name of } \\
\text { Competences }\end{array}$ & $\begin{array}{l}\text { Code Name } \\
\text { of } \\
\text { Competences }\end{array}$ & $\begin{array}{l}\text { Labour per } \\
\text { Competence } \\
\text { (Before changing } \\
\text { coefficient) }\end{array}$ & $\begin{array}{l}\text { Labour per Competence } \\
\text { (After changing } \\
\text { coefficient) }\end{array}$ \\
\hline $\begin{array}{l}\text { accept own } \\
\text { accountability }\end{array}$ & GC01 & 59.97873059 & 59.73359541 \\
\hline act reliably & $\mathrm{GCO} 2$ & 259.4880018 & 258.6379333 \\
\hline $\begin{array}{l}\text { adapt to changing } \\
\text { situations }\end{array}$ & GC03 & 1025.200972 & 1018.206009 \\
\hline $\begin{array}{l}\text { address problems } \\
\text { critically }\end{array}$ & GC04 & 60.0035273 & 59.73679399 \\
\hline $\begin{array}{l}\text { adhere to } \\
\text { organisational } \\
\text { guidelines } \\
\end{array}$ & GC05 & 10744.08881 & 10408.40888 \\
\hline advocate for others & GC06 & 59.97873059 & 59.73359541 \\
\hline $\begin{array}{l}\text { analyse goal } \\
\text { progress }\end{array}$ & GC07 & 10679.43143 & 10344.14712 \\
\hline $\begin{array}{l}\text { apply company } \\
\text { policies }\end{array}$ & GC08 & 1025.200972 & 1018.206009 \\
\hline $\begin{array}{l}\text { apply safety } \\
\text { management }\end{array}$ & GC09 & 259.4880018 & 258.6379333 \\
\hline $\begin{array}{l}\text { apply statistical } \\
\text { analysis } \\
\text { techniques }\end{array}$ & GC10 & 72.80226248 & 72.32337845 \\
\hline $\begin{array}{l}\text { arrange special } \\
\text { events }\end{array}$ & GC11 & 9.599145303 & 9.524946038 \\
\hline $\begin{array}{l}\text { build business } \\
\text { relationships }\end{array}$ & GC12 & 1357.491236 & 1349.167321 \\
\hline chair a meeting & GC13 & 4.768218921 & 4.768218921 \\
\hline coach employees & GC14 & 259.4880018 & 258.6379333 \\
\hline $\begin{array}{l}\text { comprehend } \\
\text { financial business } \\
\text { terminology }\end{array}$ & GC15 & 259.4880018 & 258.6379333 \\
\hline $\begin{array}{l}\text { control of } \\
\text { expenses }\end{array}$ & GC16 & 9.599145303 & 9.524946038 \\
\hline $\begin{array}{l}\text { deal with pressure } \\
\text { from unexpected } \\
\text { circumstances }\end{array}$ & GC17 & 0.024796707 & 0.003198578 \\
\hline
\end{tabular}




\begin{tabular}{|l|l|l|l|}
\hline $\begin{array}{l}\text { Name of } \\
\text { Competences }\end{array}$ & $\begin{array}{l}\text { Code Name } \\
\text { of }\end{array}$ & $\begin{array}{l}\text { Labour per } \\
\text { Competence } \\
\text { (Before changing } \\
\text { coefficient) }\end{array}$ & $\begin{array}{l}\text { Labour per Competence } \\
\text { (After changing } \\
\text { coefficient) }\end{array}$ \\
\hline $\begin{array}{l}\text { define quality } \\
\text { standards }\end{array}$ & GC18 & 6.894287349 & 6.894287349 \\
\hline delegate activities & GC19 & 24.01296861 & 24.01296861 \\
\hline $\begin{array}{l}\text { develop } \\
\text { organisational } \\
\text { policies }\end{array}$ & GC20 & 13.46014578 & 13.46014578 \\
\hline $\begin{array}{l}\text { devise special } \\
\text { promotions }\end{array}$ & GC21 & 9.599145303 & 9.524946038 \\
\hline $\begin{array}{l}\text { ensure customer } \\
\text { focus }\end{array}$ & GC22 & 1025.200972 & 1018.206009 \\
\hline $\begin{array}{l}\text { establish daily } \\
\text { priorities }\end{array}$ & GC23 & 4.768218921 & 4.768218921 \\
\hline $\begin{array}{l}\text { evaluate } \\
\text { employees work }\end{array}$ & GC24 & 64.10249716 & 63.95743924 \\
\hline $\begin{array}{l}\text { forecast account } \\
\text { metrics }\end{array}$ & GC25 & 1025.200972 & 1018.206009 \\
\hline $\begin{array}{l}\text { have computer } \\
\text { literacy }\end{array}$ & GC26 & 259.4880018 & 258.6379333 \\
\hline hire new personnel & GC27 & 21.50051971 & 21.10491579 \\
\hline manage budgets & GC28 & 269.1872536 & 268.3276337 \\
\hline manage resources & GC29 & 10655.71527 & 10320.67609 \\
\hline manage staff & GC30 & 15.79476335 & 15.55320228 \\
\hline $\begin{array}{l}\text { plan medium to } \\
\text { long term } \\
\text { objectives }\end{array}$ & GC31 & 0.024796707 & 0.003198578 \\
\hline present reports & GC32 & 0.024796707 & 0.003198578 \\
\hline recruit employees & GC33 & 15.76996665 & 15.5500037 \\
\hline $\begin{array}{l}\text { speak different } \\
\text { languages }\end{array}$ & GC34 & 1025.200972 & 1018.206009 \\
\hline supervise staff & GC35 & 0.024796707 & 0.003198578 \\
\hline train employees & GC36 & 43.52660129 & 43.39180047 \\
\hline $\begin{array}{l}\text { use } \\
\text { communication } \\
\text { techniques }\end{array}$ & GC37 & 1025.200972 & 1018.206009 \\
\hline
\end{tabular}

Table 9 General competence list with total labour both before and after changing coefficient values

The following graph shows the changes of labour according to changes competences 


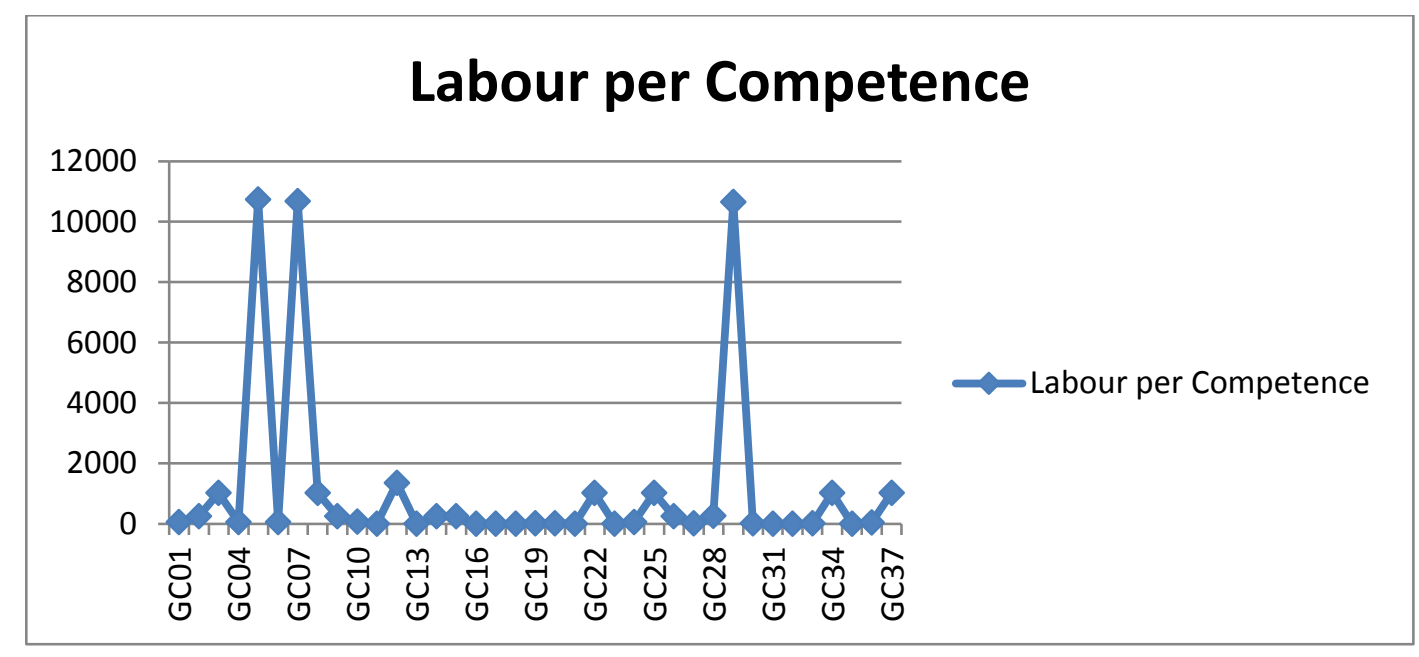

Figure 24 The graph of changes labour according to general competences

Due to the forecasted changes on mid-term (3-5 years), we can see occupation distribution in terms of the number of the employed people in the different sectors of the economy are significant. As the weighted number of employees in managerial position will go together with changes of relative importance of individual competences. After having analysed the volume changes in the original occupation structure, we can see, the changes would have effect on the demand for specific competences. Our analysis shows some of the managerial competences become much more important, other groups still more important, but not that much. The results summarized in the table below:

\begin{tabular}{|l|l|l|}
\hline GC05 & adhere to organisational guidelines & A \\
\hline GC07 & analyse goal progress & A \\
\hline GC12 & build business relationships & A \\
\hline GC29 & manage resources & A \\
\hline GC03 & adapt to changing situations & B \\
\hline GC08 & apply company policies & B \\
\hline GC22 & ensure customer focus & B \\
\hline GC25 & forecast account metrics & B \\
\hline GC34 & speak different languages & B \\
\hline
\end{tabular}




\begin{tabular}{|l|l|l|} 
GC37 & use communication techniques & B \\
\hline GC02 & act reliably & C \\
\hline GC09 & apply safety management & C \\
\hline GC14 & coach employees & C \\
\hline GC15 & $\begin{array}{l}\text { comprehend financial business } \\
\text { terminology }\end{array}$ & C \\
\hline GC26 & have computer literacy & C \\
\hline GC28 & manage budgets & C \\
\hline
\end{tabular}

Table 10 Competences in three groups

High demand will be for the competences exhibited in Group A: adhere to organisational guidelines, analyse goal progress, build business relationships and manage resources. The possible explanation of the increased importance of the mentioned competences may come from the long-term changes of global economy. As after the first and second economy, the third economy is getting more and more room in production of GDP. Production and service industries are augmented in a growing extent by civil organisation, also the spread out of atypical work, remote offices, virtual companies or operating globally and in the virtual space demand a deeper and granulated understanding what is the organisation, how to create understand, decompose strategy of the organisation. The traditional business relations are also augmented by new relations, e.g. the high level of cooperating partners in the production sphere, or the outsourced service options creates new types of business relations. In general we can say, the digital transformation radically changes the organisational scope of business, and although understanding business scope, strategy, business network are not new competence requirements, the need in terms of volume of educated employees, managers will increase and this must have an effect on the portfolio of educational institutions.

Group B: (adapt to changing situations, apply company policies, ensure customer focus, forecast account metrics, speak different languages, use of communication techniques) can be divide into two subgroups. Adaptation, adaptive company policies, customer focus may rise (in line with the Group A competences, explained above) from the fact, that digital transformation necessarily results widening the 
global business connections. To act regionally or globally the ability to adapt is a must, and here we can add, not only in business sense, but cultural sense as well. The extended interpretation explains why the subgroup 2 (speak different languages, use of communication techniques) goes together with subgroup 1.

Group C (act reliably, apply safety management, coach employees, comprehend financial business terminology, have computer literacy, manage budgets) emphasizes those competences which are focus more on managing better and different way of human resources. We expect more and deeper understanding the role of attitude (act reliably, apply safety management, coach employees) in the everyday operations (cf. recently Nobel prized behavioural economy theory). Reliability, paying attention to safety, spend more time to individual, customized training, like coaching - all investment in human resources. In other word, we may draw the conclusion, demand for not only responsible organisation but responsible performers will increase significantly. The rest of the competences in Group $\mathrm{C}$ can be considered as a consequence of those ones that mentioned above. Understanding budgeting or in broader sense locating, re-locating resources is not an isolated action on the top floor of corporate headquarter. In harmony with the Group A competences, the new types of businesses, the spread out of atypical work also goes together with the competence of responsible resource assignment. Understanding finance, the financial slang, vocabulary is also a must if budgeting is not entirely internal issue, but goes with high level involvement of external players. Crowdsourcing or micro-finance are good examples which already justify the presence and increasing importance of the mentioned competence group. Digital literacy is very much a precondition of digital transformation. 


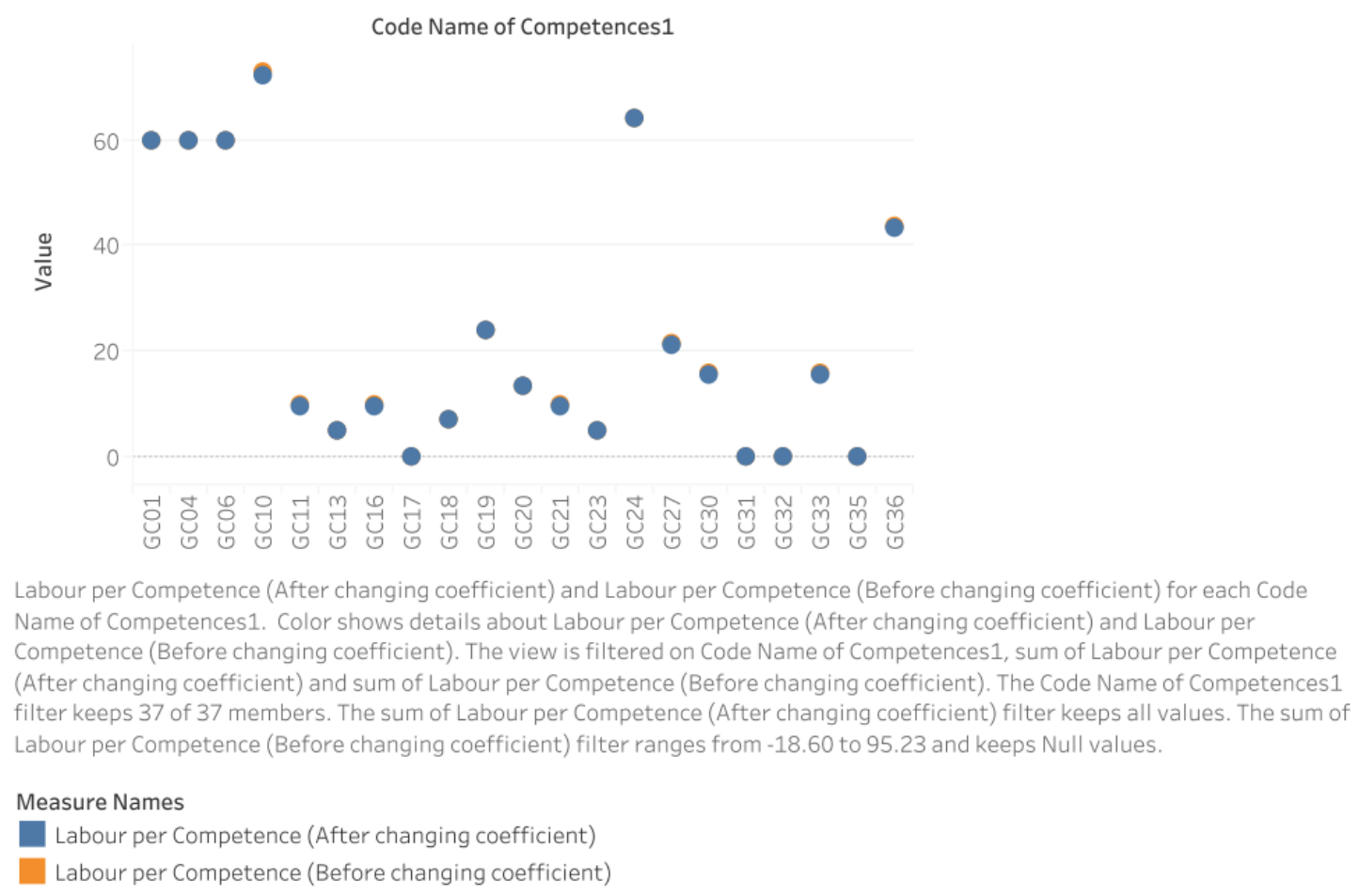

Figure 25 Difference between new situations

From Figure 25 we find that changes are not similar for all competences. Changes of labour quantities are very high for some competencies like GC01 (accept own accountability), GC04 (address problems criticially), GC06 (advocate for others). Changes almost similar for the competences GC17 (deal with pressure from unexpected circumstances), GC31 (plan medium to long term objectives), GC32 (present reports) and GC35 (supervise staff). No changes found on some competences like GC23 (establish daily priorities) or GC20 (develop organisational policies). Therefore, it can be said that by changing the coefficient values we can calculate find the competences which are more important in employment market and from where academy can take decision regarding the importance of competence development. 


\subsubsection{Sector-specific managerial competences}

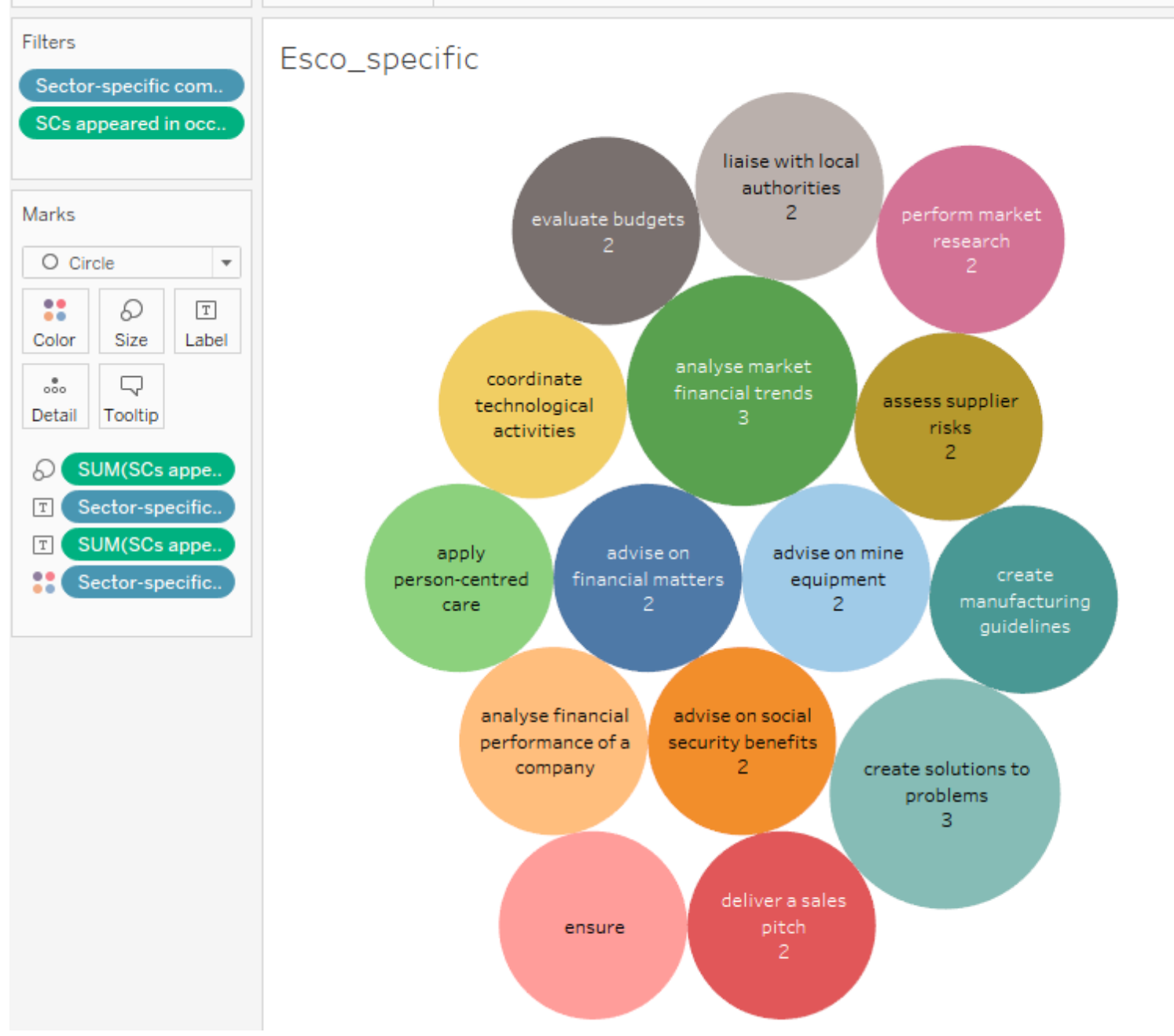

Figure 26 the distribution of sector-specific competences among the selected occupations

It seems to be that the competences connected to the element of supply chain like market research, sales, manufacturing, supply, financial activities and CSR activities are shared by more than one occupation.

The numbers of competences were weighted by the total labour output in thousands. The following chart shows the differences between the two situations (actual one and one planned by the business scenario).

In previous application of this research different type coefficients explained and input coefficient comes from a series calculation of some economic indexes. After changing coefficient value number of labours under competence also changes. 


\subsection{Validation of the model}

Concerning with building this model, this is important to validate the model using different data set and need to find a compression analysis with this result. It will be exploited to determine that a model is a correct representation of the real system. Validation is usually attained through the fine tuning of the model, a repeated process of matching the model to concrete structure behaviour and using the contradictions between two, and the discernments gained, to improve the model. This process is repeated until model accuracy is judged to be satisfactory. This task is beyond of my present study and in my future research; I hope to do work with it.

\subsection{Conclusion and future works}

There is significant mismatch between Academic Portfolio and market requirements suggested by the lack of skilled workforce. Moreover, the academia often fails to realize the future needs of the market and prepare a better workforce for the future. The economic cost incurred due to this disparity is also enormous. This framework would be used to bridge the existing gap between academic trainings and market requirements. After inputting proper data from a particular market, e.g. Hungary, to this framework, the needs of the market in the near and distant future can be predicted. An appropriate academic portfolio can be developed by using the results. The portfolio derived from this framework would then be compared with the existing academic practices to determine how effective the current portfolio is in meeting the needs of the market. As the framework is based on the economic factors that shape the market, this framework is expected to create a better academic curriculum than the existing one that does not take data-driven market study into account. Thus, a policy adjustment can be suggested to steer the academic curriculum in the right direction based on skill requirement of the future market. 
As the main goal of this paper was to make a framework to predict the future occupation; by using this result educational institution can get an assumption of their future curriculum. This study extended the understanding of the impact of economic conditions that are active in assisting industries in making job creation and on the other hand, implementing plans of action have upon academies to prepare their academic portfolio for long-term occupational outcomes. This finding points to the importance of extending career educational efforts beyond education institutes to countries and region.

After evaluating this result, the next part of my research target to match the result with the academic portfolio. It will be an Ontology based approach and will be generated an academic portfolio result by using SMART system. Nevertheless the statistical data sources were downloaded and transformed into the appropriate format manually. The system can become dynamic if these input sources are processing in automatic manner. This is another direction for future development.

The purpose of higher education should have the goal to turn out employable graduates for employers who can be plugged in from day one. The universities also exist to drive forward the boundaries of knowledge, and aim to encourage intellectual curiosity in their graduates. For this reason, university management must have the knowledge about improving their education materials. However, the question is that how university can achieve the knowledge of future job trends and how they can change their academic portfolio. The main implications of this research are to find the trends of future jobs by using different economic activities. These job trends can be used to demonstrate the guideline for the higher educational institute to prepare their curriculum which will be matched perfectly for future employment.

The analysis of the labour output development broken down by industry based on the input-output framework gives rational results. The result values on the persons employed give quite rational information which is not at first sight inconsistent with the real evolution. Nevertheless, the final values about the labour output can be utilized by a certain simplifying assumptions.

The use of the ratio of total demand of production input to output can be considered as a weakness, because as initial ratios, the 2008 values for the Hungarian economy 
were heavily influenced by the economic crisis. However, this framework can be used for any relevant year subject to find the available dataset. The second weakness is definitely the absence of occupation classification in different industry sectors as the final goal of the research to find the matching of present academic curriculum with future demand of industries. The third weakness of the model is possible inconsistency of using data from different data sources. Working with open data the danger of inconsistency is unavoidable; we need to find the adequate methods eliminating this kind of risk.

All mentioned softness will be the object of our future research. To consider the accessible data sources, the weakness related to the number of employed person based on occupation classification can be solved using the data according to the cataloguing of occupations (HU-ISCO) which might be available for well ahead years for the Hungarian economy.

On the other hand, concerning with building a model from this research, this is important to validate the model using different data set and need to find a comparison analysis with this result. It will be utilized to determine that a model is an accurate representation of the real system. This process is repeated until model accuracy is judged to be acceptable. This task is beyond of my present study and in my future research; I hope to do work with it.

The study of the labour output development broken down by industry based on the input-output framework gives rational results. The result values on the thousand persons worked give quite rational information which is not at first spectacle unpredictable with the real evolution. Nevertheless, the final values about the labour output can be utilized by a certain simplifying assumptions.

The use of the percentage of total demand of production inputs to output can be measured as dimness because as the initial ratios the values for the Hungarian economy were used for the year 2008, at the period of economic calamity. However, this framework can be used for any relevant year subject to find the available dataset. The second weakness is definitely the absence of occupation classification in different industry sectors as the final goal of the research to find the matching of present academic curriculum with future industries. The third weakness of the model 
is the assumption on the total employed person in thousand persons related to the different industries sector from another data source. Therefore, many reasons may be raised for the inconsistency of the datasets. 


\section{REFERENCES}

Åberg, R. (2003). Unemployment Persistency, Over-Education and the Employment Chances of the Less Educated. European Sociological Review, 19 (2), 199-216.

Adams, J., Greig, M., \& McQuaid, RW (2000). Mismatch unemployment and local labour -market efficiency. The role of employer and vacancy Characteristics Environment and Planning A, 32 (10) 1841-1856.

Ahmed, F. (2016, April). An Input Output Based Methodology to Find the Future Job Trends in Europe. In ECIC2016-Proceedings of the 8th European Conference on Intellectual Capital: ECIC2016 (p. 349). Academic Conferences and publishing limited.

Allen, J., \& De Weert, E. (2007). What Do Educational Mismatches Tell Us About Skill Mismatches? A Cross-country Analysis. European Journal of Education, 42(1), 59-73. DOI: 10.1111/j.1465-3435.2007.00283.x

Babbie, Rubin, A. (2001). Research Methods for Social Workers (4th ed.). Belmont.

Babbie, E. (2015). The practice of social research. Nelson Education

Barnow, B. S., Trutko, J. W., \& Piatak, J. S. (2013). Occupational labour shortages: Concepts, causes, consequences, and cures. WE Upjohn Institute. DOI: $10.17848 / 9780880994132$

Barrell, R., \& Pain, N. (1997). Foreign Direct Investment, Technological Change, and Economic Growth Within Europe. The Economic Journal, 107(445), 17701786.

Barton, J., \& Collins, A. (1993). Portfolios in teacher education. Journal of teacher education, 44(3), 200-210.

Béduwé, C., \& Gire, JF (2011). Mismatch of vocational graduates: What penalty on French labour market? Journal of Vocational Behaviour, 78 (1), 68-79. DOI: 10.1016/j.jvb.2010.09.003 
Bekhet, H. A. (2010). Output, income and employment multipliers in Malaysian economy: input-output approach. International Business Research, 4(1), p208.9. DOI: $10.5539 /$ ibr.v4n1p208

Black, S. E., \& Lynch, L. M. (2001). How to compete: the impact of workplace practices and information technology on productivity. Review of Economics and statistics, 83(3), 434-445. DOI: 10.1162/00346530152480081

Blank, D. J. and Stigler, G. J. (1957).The Demand and Supply of Scientific Personnel.

New York: National Bureau of Economic Research.

Blundell, R., \& Walker, I. (1986). Unemployment, search and labour supply. CUP Archive.

Borbás, L. (2012). Hungary's competitiveness in the light of Europe 2020 strategy. In Proceedings-10th International Conference on Mangement, Enterprise and Benchmarking (MEB 2012) (pp. 243-254). Óbuda University, Keleti Faculty of Business and Management.

Borbásné Szabó, I. (2014). Felsőoktatási portfolió kompetencia alapon történő tervezése $=$ Design of Higher Education Portfolio (Doctoral dissertation, Budapesti Corvinus Egyetem). DOI: 10.14267/phd.2014005

Brada, J. C. (1989). Technological progress and factory utilization in Eastern European economic growth. Economica, 433-448.

Brada, J. C., \& Montias, J. M. (1984). Industrial policy in Eastern Europe: A threecountry comparison. Journal of Comparative Economics, 8(4), 377-419. Chicago

Briassoulis, H. (1991). Methodological issues: tourism input-output analysis. Annals of Tourism Research, 18(3), 485-495.

Business Gargons-HR: Factors affecting employee compensation http://businessjargons.com/factors-affecting-employee-compensation.html

Cameron, N. E. (1981). Economic growth in the USSR, Hungary, and East and West Germany. Journal of Comparative Economics, 5(1), 24-42. 
Castello, V., Guerrero, J., Guspini, M., Mahajan, L., Beinhauer, R., Gabor, M. and Flores, E. (2013). Enhancing Competences dynamic alignment between job and Education. Challenges and Evidences from the SMART project. ICERI2013 Proceedings, 1430-1437.

CEDEFOP (2017a): Cedefop's European skills and jobs survey data released!, http://www.cedefop.europa.eu/en/news-and-press/news/cedefops-europeanskills-and-jobs-survey-data-released, last accessed 2017/08/21.

CEDEFOP (2017b): Briefing note - People, machines, robots and skills, http://www.cedefop.europa.eu/en/publications-and-resources/publications/9121, last accessed 2017/08/21.

Chen, T. J., \& Ku, Y. H. (2000). The effect of foreign direct investment on firm growth: the case of Taiwan's manufacturers. Japan and the World Economy, 12(2), 153-172.

Cornfield, J., Evans, W. D., \& Hoffenberg, M. (1947). Full employment patterns, 1950: Part 1. Monthly Labour Review, 64(2), 163-190.

Cörvers, F., and Hensen, M. (2007). Forecasting regional labour market developments by occupation and education (25). Manfred Tessaring (eds), 56.

Cörvers, Frank. (2003) "Labour market forecasting in the Netherlands: a top-down approach." Early identification of skill needs in Europe, Cedefop Reference Series 40 (2003): 72-83.

Cuesta, MB (2005). Youth labour market integration in Spain: Search times, job duration and skill mismatch. Spanish Economic Review, 7 (3), 191-208. DOI: 10.1007/s10108-005-0097-7

Davies, A. et al (2011).: Future work skills 2020. Institute for the Future for the University of Phoenix Research Center.

Dolphin, T. (2015). Technology, globalization and the future of work in Europe: Essays on employment in a digitized economy.

Driessen, E., Tartwijk, J. V., \& Dornan, T. (2008). The self-critical doctor: helping students become more reflective. BMJ (CR)-print, 336(7648), 827. DOI: 10.1136/bmj.39503.60803 2.ad 
Dubra, E., and Gulbe, M. (2008). Forecasting the labour force demand and supply in Latvia. Technological and economic development of economy, 14(3), 279-299. DOI: $10.3846 / 1392-8619.2008 .14 .279-299$

Ecar (2017): Half of all new cars in Norway are electric or hybrid | World Economic Forum, https://www.weforum.org/agenda/2017/03/norway-is-leading-thecharge-towards-electric-vehicles-and-just-hit-another-milestone-along-the-wayd69a8170-cbdc-4d8a-95cd-f9bdf3c8e3ae/, last accessed 2017/08/18

Encyclopedia.com, Input-Output Analysis - Dictionary definition of Input-Output Analysis | Encyclopedia.com: FREE online dictionary, http://www.encyclopedia.com/social-sciences/applied-and-social-sciencesmagazines/input-output-analysis /, last accessed 2017/08/02

ESCO Board. (2017). ESCO Stratregic Framework. [online]. Available from: https://ec.europa.eu/esco/portal/document/en/01192a20-a7c0-4d0d-b5d329d1f9b819c8.

Eurofound (2017). Articles | Eurofound. [online]. Available from: https://www.eurofound.europa.eu/observatories/eurwork/articles/\%20labourmarket-industrial-relations/hungary-skills-shortages-a-major-challenge-foremployers, last accessed 2017/11/08

European Foundation for the Improvement of Living and Working ConditionsEFILWC (2008). ERM case studies: The employment impact of relocation within the EU. Retrieved from http://www.eurofound.europa.eu/publications

European Foundation for the Improvement of Living and Working Conditions. (2013). Impact of the crisis on working conditions in Europe.

EQF. (2009). European qualifications framework (EQF). Cedefop. [online]. Available from: http://www.cedefop.europa.eu/hu/events-andprojects/projects/european-qualifications-framework-eqf [Accessed August 28, 2017].

Fletcher, J. E. (1989). Input-output analysis and tourism impact studies. Annals of tourism research, 16(4), 514-529. 
Floros, C. (2005). Forecasting the UK unemployment rate: model comparisons. International Journal of Applied Econometrics and Quantitative Studies, 2(4), $57-72$.

Franke, W. and Sobel, I. (1970). The Shortage of Skilled and Technical Workers. Lexington, Massachusetts: Heath-Lexington Books.

Frechtling, D. C., and Horvath, E. (1999). Estimating the multiplier effects of tourism expenditures on a local economy through a regional input-output model. Journal of travel research, 37(4), 324-332.

Frey, C. B., \& Osborne, M. A. (2013). The future of employment: how susceptible are jobs to computerization. Retrieved September, 7, 2013. DOI: 10.1016/j.techfore.2016.08.019

Frigant, V., \& Layan, J. B. (2009). Modular production and the new division of labour within Europe: the perspective of French automotive parts suppliers. European Urban and Regional Studies, 16(1), 11-25. DOI: $10.1177 / 0969776408098930$

García-Aracil, A., \& Van der Velden, R. (2008). Competencies for young European higher education graduates: labour market mismatches and their payoffs. Higher Education, 55(2), 219-239. DOI: 10.1007/s10734-006-9050-4

Garino, G., \& Martin, C. (2007). The impact of labour turnover: theory and evidence from UK micro-data.

Glennon, D., Lane, J., \& Johnson, S. (1987). Regional econometric models that reflect labour market relations. International Journal of Forecasting, 3(2), 299312.

Globerman, S. (1979). Foreign direct investment and 'spillover' efficiency benefits in Canadian manufacturing industries. Canadian journal of economics, 42-56

Greenwood, J., MacDonald, G. M., \& Zhang, G. J. (1996). The cyclical behaviour of job creation and job destruction: a sectoral model. Economic Theory, 7(1), 95112. 
Hartmann, E.A., Bovenschulte, M. (2013): Skills needs analysis for "Industry 4.0" based on roadmaps for smart systems. In: Using Technology Foresights for Identifying Future Skills Needs. Global Workshop Proceedings. pp. 24-36

Hamilton, J. (2012). Electric Vehicle Careers: On the Road to Change. Occupational Outlook Quarterly, 56(2), 14-21.

Howell, D. R. (1985). The future employment impacts of industrial robots: An inputoutput approach. Technological Forecasting and Social Change, 28(4), 297-310.

Inclusion and diversity in work groups: A review and model for future research. Journal of Management, 0149206310385943.

Jahoda, M. (1981). Work, employment, and unemployment: Values, theories, and approaches in social research. American psychologist, 36(2), 184.

Kluemper, D. H., \& Rosen, P. A. (2009). Future employment selection methods: evaluating social networking web sites. Journal of managerial Psychology, 24(6), 567-580. DOI: 10.1108/02683940910974134

Levy, F., \& Murnane, R. J. (2012). The new division of labour: How computers are creating the next job market. Princeton University Press. DOI: $10.1177 / 009430610603500424$

le Vrang, M. et al. (2014). ESCO: Boosting job matching in Europe with semantic interoperability. Computer, 47(10), pp.57-64. DOI: 10.1109/mc.2014.283

Lehmann, R., \& Wohlrabe, K. (2014). Regional economic forecasting: state-of-theart methodology and future challenges. DOI: 10.17811/ebl.3.4.2014.218-231

Leontief, W. W. (1936). Quantitative input and output relations in the economic systems of the United States. The review of economic statistics, 105-125.

Linse, A., Turns, J., Yellin, J. M., \& Van De Grift, T. (2004, June). Preparing future engineering faculty: Initial outcomes of an innovative teaching portfolio program. In Proceedings of the of the 2004 American Society for Engineering Education Annual Conference and Exposition, Session (Vol. 3555).

Little, B. (2001). Reading between the lines of graduate employment. Quality in Higher Education, 7(2), 121-129. DOI: 10.1080/13538320120060015 
Loughran, J., \& Corrigan, D. (1995). Teaching portfolios: A strategy for developing learning and teaching in preservice education. Teaching and teacher education, 11(6), 565-577.

Marey, P., de Grip, A., and Cörvers, F. (2001). Forecasting the labour markets for research scientists and engineers in the European Union. Research centrum voor Onderwijsen Arbeidsmarkt, Faculteit der Economische Wetenschappenen Bedrijfskunde, Universiteit Maastricht.

Mason, G. (2002). High skills UTILISATION under Mass Higher Education. Graduate employment in service industries in Britain, Journal of Education and Work, 15 (4), 427-456. DOI: 10.1080/1363908022000023560

Meagher, D. T., and Pang, F. (2011). Labour Market Forecasting, Reliability and Workforce Development. DEEWR.

Miller, R. B., \& Brickman, S. J. (2004). A model of future-oriented motivation and self-regulation. Educational Psychology Review, 16(1), 9-33. DOI: 10.1023/b:edpr.0000012343 96370.39

Minor, O., and Armarego, J. (2007). Requirements Engineering: a close look at industry needs and a model curricula. Australasian Journal of Information Systems, 13(1). DOI: 10.3127/ajis.v13i1.71

Moreno Minguez, A. (2013). The Employability of Young People in Spain. The Mismatch between Education and Employment Online Submission, 3 (5), 334344.

Morris, M. G., \& Venkatesh, V. (2000). Age differences in technology adoption decisions: Implications for a changing work force. Personnel psychology, 53(2), 375-403. DOI: 10.1111/j.1744-6570.2000.tb00206.x

NeSkNeJo (2015): New Skills for New Jobs. Policy initiatives in the field of education: Short overview of the current situation in Europe. EACEA: [online] http://eacea.ec.europa.eu/education/eurydice/documents/thematic_reports/125E N.pdf last accessed 2015/06/09

Newman, I. and Benz, C.R. (1998). Qualitative-quantitative research methodology: Exploring the interactive continuum. SIU Press. 
Nielsen, R. P. (1984). Industrial policy: the case for national strategies for world markets. Long Range Planning, 17(5), 50-59.

OECD (2017): Skill for a Digital World, http://www.oecd.org/els/emp/Skills-for-aDigital-World.pdf, last accessed 2017/08/21.

Parikh, A., and Edwards, R. (1980). An input-output approach to forecasting gross domestic output and employment intensities by sectors. Empirical Economics, 5(1), 1-14.

Parker, S. K., Wall, T. D., \& Cordery, J. L. (2001). Future work design research and practice: Towards an elaborated model of work design. Journal of occupational and organizational psychology, 74(4), 413-440. DOI: $10.1348 / 096317901167460$

Rae, D. (2007). Connecting enterprise and graduate employability: challenges to the higher education culture and curriculum? Education+ Training, 49(8/9), 605619. DOI: $10.1108 / 00400910710834049$

Rumberger, R. W., \& Levin, H. M. (1985). Forecasting the impact of new technologies on the future job market. Technological Forecasting and Social Change, 27(4), 399-417.

Schanne, N. (2010). Forecasting regional labour markets with GVAR models and indicators. mimeo). http://www-sre. wu. ac. at /ersa /ersaconfs /ersa10 / ERSA2010finalpaper1044. pdf.

Schneider, J. (2004). Evaluating and Improving Undergraduate Teaching in Science, Technology, Engineering and Mathematics. Community Colle'ge Enterprise, 10(1), 103. DOI: 10.17226/10024

Smart Plus Project (2017): Official Website, http://smartplus-project.org/, last accessed 2017/08/28

Smart-Project (2015), http://www.smart-project.org/, last accessed 2017/08/28

Sonis, M., and Hewings, G. J. (2007). Coefficient Change and Innovation Spread in Input Output Models. Juiz de Fora: FEA/UFJF, 4, 2007. 
Stilwell, L. C., \& Minnitt, R. C. A. (2000). Input-output analysis: its potential application to the mining industry. The Journal of The South African Institute of Mining and Metalurgy, 455-460. DOI: 10.1016/s0301-4207(00)00013-1

Teichler, U. (2000). Graduate employment and work in selected European countries. European Journal of Education, 35 (2), 141-156. DOI: 10.1111/14673435.00013

Teichler, U. (2007). Does Higher Education Matter? Lessons from the comparative graduate survey. European Journal of Education, 42 (1), 11-34. DOI:

10.1111/j.1465-3435.2007 .00287.x

Teichler, U., \&Kehm, B. M. (1995). Towards a new understanding of the relationships between higher education and employment. European Journal of Education, 115-132.

"The Japanese Economy and the 2005 Input-Output Tables", published by the Director-General for Policy Planning, Ministry of Internal Affairs and Communication, Japan, 2009. http://www.soumu.go.jp/main_content/000327480.pdf

Thomas, D. S. M. (1998). The use of portfolio learning in medical education. Medical Teacher, 20(3), 192-199.

Urbaitè, Ū., Gruodis, A., Stankevičienè, J., and Lokutijevskij, A. (2012). Building Lithuanian Macro-Econometric Model: Forecast of Average Wages and Unemployment Rate. Intelektinè ekonomika, (6 (1), 754-775.

van Essen, H., Kaupman, B.: Impacts of electric vehicles: summary report. (2011). DOI: $10.1787 / 9789264072930-10-\mathrm{fr}$

Weligamage, S. S. (2009). Graduates ${ }^{e e}$ Employability Skills: Evidence from Literature Review. University of Kelaniya, Sri Lanka.

Weligamage, S., and Siengthai, S. (2003, November). Employer Needs and Graduate Skills: The Gap between Employer Expectations and Job Expectations of Sri Lankan University Graduates. In 9th International conference on Sri Lanka Studies. Matara, Sri Lanka. 
Wieling, M., and Borghans, L. (2001). Discrepancies between supply and demand and adjustment processes in the labour market. Labour, 15(1), 33-56. DOI: 10.1111/1467-9914.00154

Willems, E. J. T. A. (1996). Manpower forecasting and modelling replacement demand: an overview. Research Centre for Education and Labour Market, Faculty of Economic Sciences, Rijksuniversiteit Limburg.

World Economic Forum. (2016). The future of jobs: employment, skills and workforce strategy for the fourth industrial revolution. World Economic Forum, Geneva, Switzerland.

Zbranek, J., and Sixta, J. (2012). Analysis of the labour inputs in the input-output framework. In 20th IIOA conference in Bratislava.[online]. Bratislava (Vol. 25, No. 2012, pp. 29-06). 


\section{ANNEXES}

\subsection{Table-1 Supply and Use Table}

(at basic prices including transformation into purchasers' prices by using NACE Rev. 2 main industries classification)

\begin{tabular}{|c|c|c|c|c|c|c|c|c|c|c|c|c|c|c|c|c|c|c|c|c|}
\hline $\begin{array}{l}\text { o } \\
d \\
\text { e }\end{array}$ & A & B & $\mathrm{C}$ & D & $\mathrm{E}$ & $\mathrm{F}$ & $\mathrm{G}$ & $\mathrm{H}$ & I & $\mathbf{J}$ & $\mathrm{K}$ & $\mathrm{L}$ & $\mathrm{M}$ & $\mathrm{N}$ & $\mathrm{O}$ & $\mathrm{P}$ & Q & $\mathrm{R}$ & $S$ & $\begin{array}{l}\mathrm{T} \\
\mathrm{O} \\
\mathrm{T} \\
\mathrm{A} \\
\mathrm{L}\end{array}$ \\
\hline A & 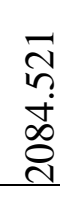 & $\begin{array}{l}2 \\
2 \\
2 \\
6 \\
0 \\
0\end{array}$ & $\begin{array}{l}0 \\
\infty \\
0 \\
\infty \\
0 \\
0 \\
0\end{array}$ & 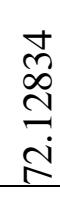 & 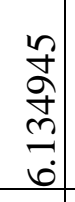 & 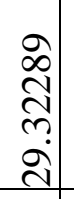 & 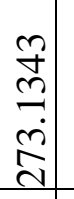 & $\begin{array}{l}1 \\
\tilde{n} \\
n \\
0 \\
\infty \\
0\end{array}$ & 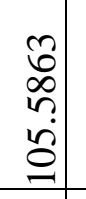 & $\begin{array}{l}\frac{9}{5} \\
0 \\
i n \\
+ \\
\dot{+}\end{array}$ & 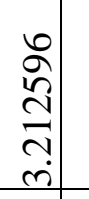 & $\begin{array}{c}\infty \\
\infty \\
\pm \\
\stackrel{ \pm}{r} \\
\dot{\Xi}\end{array}$ & $\begin{array}{l}\mathbb{N} \\
\widehat{\widehat{N}} \\
0 \\
\infty \\
0\end{array}$ & 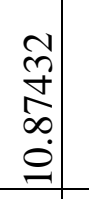 & $\begin{array}{c}n \\
0 \\
0 \\
+ \\
0 \\
\\
\end{array}$ & $\begin{array}{c}n \\
\vdots \\
0 \\
\infty \\
\dot{v} \\
ن\end{array}$ & 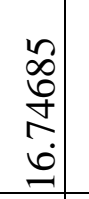 & 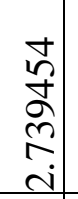 & 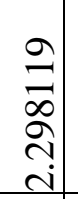 & $\begin{array}{l}N \\
n \\
\infty \\
i n \\
i n\end{array}$ \\
\hline B & 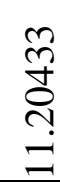 & $\begin{array}{l}\infty \\
8 \\
8 \\
\stackrel{2}{2} \\
\stackrel{7}{1}\end{array}$ & 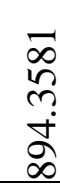 & 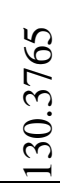 & $\begin{array}{l}\mathbb{J} \\
\infty \\
\infty \\
\sim \\
\infty \\
\dot{n}\end{array}$ & 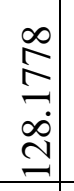 & $\begin{array}{l}\sqrt{ } \\
\infty \\
\infty \\
0 \\
0 \\
0 \\
0\end{array}$ & $\begin{array}{l}\stackrel{+}{ } \\
\stackrel{\sigma}{0} \\
0 \\
0\end{array}$ & $\begin{array}{l}\infty \\
r \\
\hat{n} \\
\infty \\
0 \\
\dot{m}\end{array}$ & 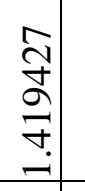 & $\begin{array}{c}0 \\
\tilde{n} \\
\tilde{\sigma} \\
0 \\
-\end{array}$ & 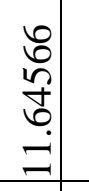 & 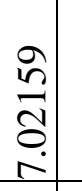 & \begin{tabular}{c}
$\infty$ \\
$\infty$ \\
\hdashline \\
$\infty$ \\
ஸे \\
$\dot{m}$
\end{tabular} & 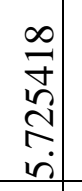 & 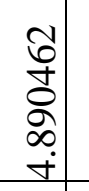 & 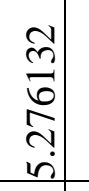 & $\begin{array}{l}0 \\
0 \\
2 \\
o \\
0 \\
0\end{array}$ & 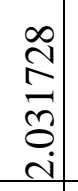 & 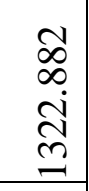 \\
\hline $\mathrm{C}$ & 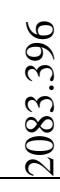 & $\begin{array}{l}m \\
\infty \\
\infty \\
0 \\
\dot{J}\end{array}$ & \begin{tabular}{l}
0 \\
0 \\
$\sigma$ \\
$\infty$ \\
\multirow{\sigma}{+}{}
\end{tabular} & 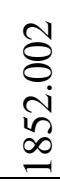 & 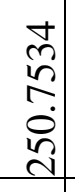 & 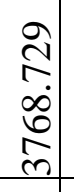 & $\begin{array}{c}0 \\
+ \\
+ \\
i \\
\dot{b} \\
\text { d. }\end{array}$ & $\begin{array}{l}\vec{D} \\
\infty \\
\dot{\vec{j}} \\
\overrightarrow{\mathrm{d}}\end{array}$ & $\begin{array}{l}\vec{J} \\
\dot{J} \\
\mathrm{i} \\
\text { ป̦ }\end{array}$ & 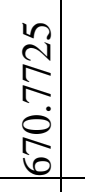 & 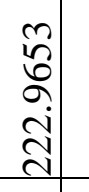 & $\begin{array}{l}\infty \\
\tilde{r} \\
\tilde{r} \\
\dot{\sigma} \\
\sigma\end{array}$ & 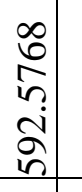 & 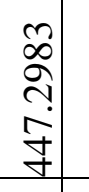 & $\begin{array}{l}m \\
\infty \\
\mathfrak{n} \\
m \\
m \\
m\end{array}$ & 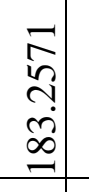 & 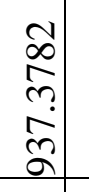 & $\begin{array}{l}\bar{N} \\
\tilde{n} \\
=\end{array}$ & 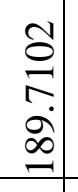 & $\begin{array}{l}\infty \\
\infty \\
6 \\
0 \\
6 \\
6\end{array}$ \\
\hline D & 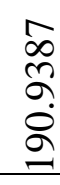 & $\begin{array}{l}\infty \\
\infty \\
\infty \\
\infty \\
\end{array}$ & $\begin{array}{l}\bar{\sigma} \\
\stackrel{2}{\circ} \\
\infty\end{array}$ & 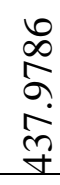 & 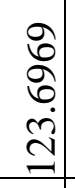 & 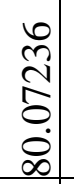 & 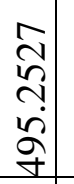 & 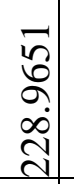 & 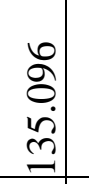 & $\begin{array}{c}\widehat{\sigma} \\
= \\
i \\
=\end{array}$ & 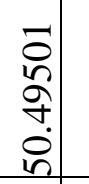 & $\begin{array}{c}\bar{\sigma} \\
\stackrel{+}{+} \\
\dot{\infty} \\
\end{array}$ & 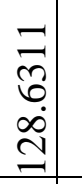 & 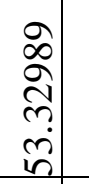 & $\begin{array}{l}m \\
\infty \\
0 \\
n \\
n \\
n\end{array}$ & 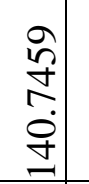 & $\begin{array}{l}n \\
\hat{\sigma} \\
n \\
=\end{array}$ & 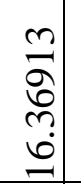 & 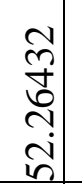 & 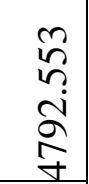 \\
\hline $\mathrm{E}$ & $\begin{array}{l}\hat{8} \\
\hat{n} \\
\hat{\sigma} \\
\text { ลे }\end{array}$ & $\begin{array}{l}\overline{0} \\
8 \\
8 \\
\text { ㄱ. }\end{array}$ & 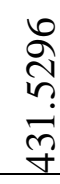 & 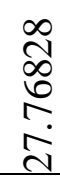 & 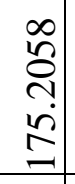 & 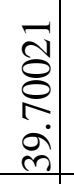 & 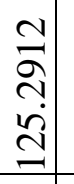 & 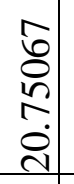 & $\begin{array}{c}\stackrel{n}{ \pm} \\
\stackrel{n}{m} \\
\dot{m}\end{array}$ & 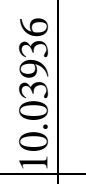 & 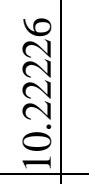 & $\begin{array}{l}\overline{0} \\
\hat{\delta} \\
\infty \\
\dot{n} \\
\dot{n}\end{array}$ & \begin{tabular}{l}
$n$ \\
$\hat{\sigma}$ \\
\multirow{6}{0}{} \\
0
\end{tabular} & $\begin{array}{c}\hat{0} \\
\overline{8} \\
\dot{\delta} \\
\dot{\gamma}\end{array}$ & 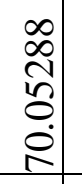 & 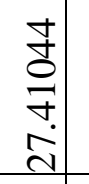 & 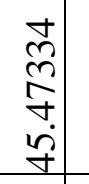 & 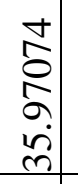 & 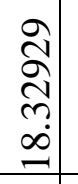 & $\begin{array}{l}\text { J } \\
\text { t. } \\
\text { શิ } \\
=\end{array}$ \\
\hline $\mathrm{F}$ & 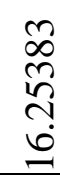 & 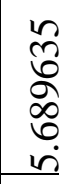 & $\begin{array}{l}\text { مे } \\
\text { ণे } \\
\text { ণे }\end{array}$ & 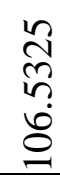 & 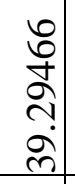 & 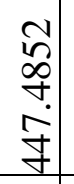 & 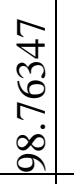 & 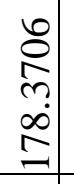 & 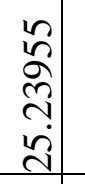 & 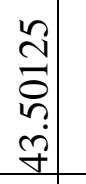 & $\begin{array}{l}m \\
\tilde{n} \\
\tilde{\sigma} \\
\tilde{n} \\
a\end{array}$ & 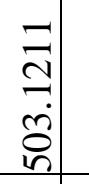 & $\begin{array}{l}\bar{a} \\
\widehat{\sigma} \\
\infty \\
\dot{8}\end{array}$ & 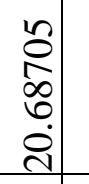 & $\begin{array}{l}n \\
\tilde{n} \\
\tilde{0} \\
\tilde{n}\end{array}$ & 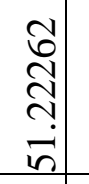 & 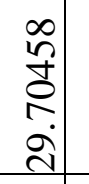 & 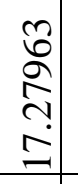 & 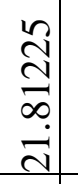 & 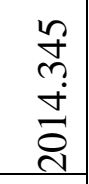 \\
\hline $\mathrm{G}$ & $\begin{array}{l}n \\
\tilde{\sigma} \\
\dot{0} \\
\frac{ \pm}{n}\end{array}$ & $\begin{array}{l}2 \\
\infty \\
\infty \\
\infty \\
0\end{array}$ & $\begin{array}{l}= \\
\infty \\
n \\
n \\
n \\
n\end{array}$ & 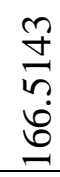 & 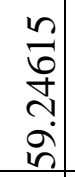 & $\begin{array}{l}c \\
\infty \\
n \\
n \\
n \\
a\end{array}$ & $\begin{array}{l}\sqrt{\infty} \\
\infty \\
0 \\
\dot{0} \\
\pm\end{array}$ & $\begin{array}{l}\infty \\
\\
\\
n\end{array}$ & 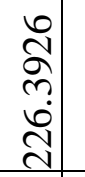 & 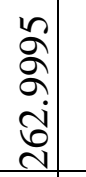 & 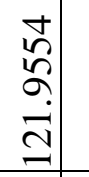 & 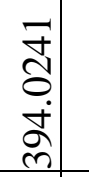 & $\begin{array}{l}\stackrel{+}{f} \\
\stackrel{f}{.} \\
\stackrel{a}{+}\end{array}$ & 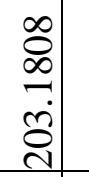 & $\begin{array}{l}\infty \\
\stackrel{2}{N} \\
\infty \\
\infty \\
\dot{\infty}\end{array}$ & 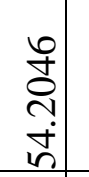 & $\begin{array}{l}\wp \\
\infty \\
0 \\
0 \\
\infty \\
\infty\end{array}$ & $\begin{array}{l}n \\
n \\
n \\
+\infty \\
a \\
a\end{array}$ & 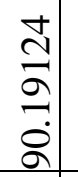 & 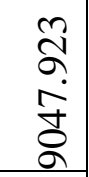 \\
\hline $\mathrm{H}$ & $\begin{array}{l}\text { f } \\
\text { f } \\
\text { 워 }\end{array}$ & $\begin{array}{l}\infty \\
\text { ని } \\
\square\end{array}$ & $\begin{array}{l}\bar{\delta} \\
\text { ஸे } \\
\approx \\
\infty\end{array}$ & 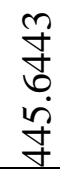 & 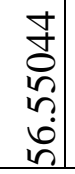 & $\begin{array}{l}n \\
m \\
\tilde{n} \\
\tilde{n}\end{array}$ & 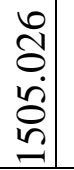 & 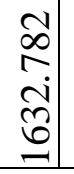 & $\begin{array}{l}\hat{2} \\
\hat{0} \\
0 \\
2 \\
\end{array}$ & 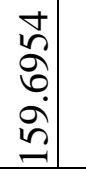 & $\begin{array}{l}\infty \\
\stackrel{2}{8} \\
\infty \\
\dot{0}\end{array}$ & $\begin{array}{c}\infty \\
5 \\
0 \\
\infty \\
\infty \\
\end{array}$ & $\begin{array}{l}m \\
\bar{g} \\
\dot{J} \\
\dot{J}\end{array}$ & 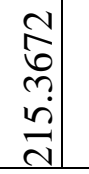 & $\begin{array}{l}n \\
\sigma \\
n \\
\infty \\
\tilde{n} \\
n\end{array}$ & 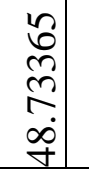 & 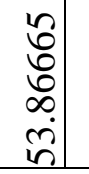 & $\begin{array}{l}\sqrt{n} \\
\\
\\
n\end{array}$ & 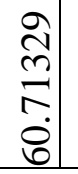 & $\begin{array}{l}\text { ஜิ } \\
\text { o. } \\
\text { ñ }\end{array}$ \\
\hline
\end{tabular}




\begin{tabular}{|c|c|c|c|c|c|c|c|c|c|c|c|c|c|c|c|c|c|c|c|c|}
\hline $\begin{array}{l}\mathrm{O} \\
\mathrm{d}\end{array}$ & A & B & C & D & E & $\mathrm{F}$ & $\mathrm{G}$ & $\mathrm{H}$ & I & $\mathbf{J}$ & K & $\mathrm{L}$ & $\mathrm{M}$ & $\mathrm{N}$ & $\mathrm{O}$ & $P$ & Q & $\mathrm{R}$ & $S$ & $\begin{array}{l}\mathrm{T} \\
\mathrm{O} \\
\mathrm{T} \\
\mathrm{A} \\
\mathrm{L}\end{array}$ \\
\hline I & $\begin{array}{l}\bar{n} \\
\sqrt[n]{ } \\
\dot{J} \\
\dot{v}\end{array}$ & $\begin{array}{l}\frac{n}{\infty} \\
\frac{1}{0} \\
? \\
0\end{array}$ & 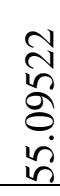 & 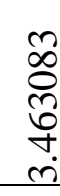 & 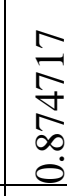 & 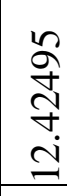 & \begin{tabular}{l}
$\stackrel{2}{2}$ \\
2 \\
\multirow{2}{*}{} \\
\multirow{\gamma}{y}{}
\end{tabular} & \begin{tabular}{l}
$\infty$ \\
$\infty$ \\
$\infty$ \\
\multirow{2}{*}{} \\
$\infty$ \\
$\infty$
\end{tabular} & $\begin{array}{l}\bar{\sigma} \\
\tilde{\sigma} \\
\dot{0} \\
\approx \\
\end{array}$ & $\begin{array}{l}N \\
\hat{\sigma} \\
\underline{0} \\
\end{array}$ & $\begin{array}{l}n \\
7 \\
n \\
n \\
n \\
n\end{array}$ & 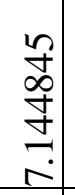 & $\begin{array}{l}\tilde{b} \\
\dot{+} \\
\sigma \\
\dot{\gamma} \\
\dot{v}\end{array}$ & 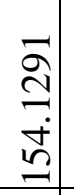 & 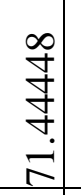 & $\begin{array}{l}\infty \\
\stackrel{\infty}{a} \\
\stackrel{\sim}{0}\end{array}$ & $\begin{array}{c}9 \\
\infty \\
m \\
\dot{v} \\
\dot{b}\end{array}$ & 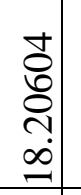 & 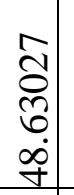 & 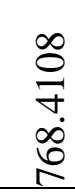 \\
\hline $\mathrm{J}$ & $\begin{array}{l}\text { กิ } \\
\text { Nิ } \\
\frac{\pi}{n}\end{array}$ & 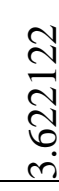 & \begin{tabular}{l}
$\bar{Z}$ \\
\multirow{2}{*}{} \\
న
\end{tabular} & 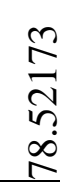 & $\begin{array}{l}n \\
n \\
+ \\
\sigma \\
\infty \\
\infty\end{array}$ & 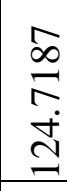 & 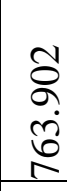 & $\begin{array}{l}\text { ปै } \\
\delta \\
\stackrel{d}{0} \\
\tilde{v}\end{array}$ & $\begin{array}{l}0 \\
\infty \\
2 \\
\hat{\sigma} \\
\hat{0} \\
\hat{n}\end{array}$ & 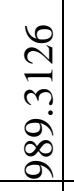 & $\begin{array}{l}n \\
\tilde{n} \\
\tilde{n} \\
\tilde{n}\end{array}$ & 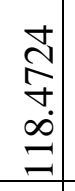 & 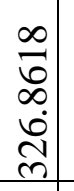 & $\begin{array}{l}\sigma \\
6 \\
6 \\
\dot{\infty} \\
\infty\end{array}$ & $\begin{array}{c}\infty \\
m \\
0 \\
\dot{d} \\
\end{array}$ & $\begin{array}{l}0 \\
\infty \\
2 \\
\infty \\
\stackrel{0}{ \pm}\end{array}$ & $\begin{array}{l}2 \\
\infty \\
\infty \\
+ \\
\vdots \\
i \\
i\end{array}$ & $\begin{array}{l}\hat{b} \\
\infty \\
\grave{2} \\
\grave{c}\end{array}$ & 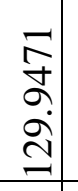 & \begin{tabular}{l}
$\infty$ \\
\multirow{2}{*}{} \\
$\stackrel{2}{2}$ \\
\multirow{\gamma}{*}{}
\end{tabular} \\
\hline K & 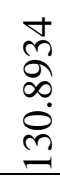 & 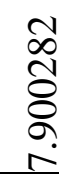 & $\begin{array}{l}\stackrel{8}{0} \\
\frac{m}{6} \\
\frac{1}{n}\end{array}$ & 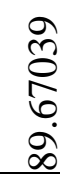 & $\begin{array}{l}\bar{\delta} \\
\text { ర్ర } \\
\text { m }\end{array}$ & 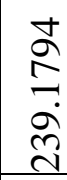 & 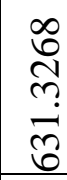 & 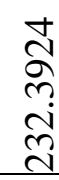 & \begin{tabular}{|l|}
$\infty$ \\
0 \\
0 \\
0 \\
0 \\
0 \\
0 \\
$\infty$
\end{tabular} & 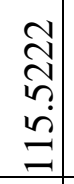 & $\begin{array}{l}n \\
n \\
n \\
\delta \\
\delta \\
\end{array}$ & 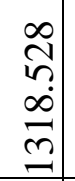 & $\begin{array}{c}\infty \\
0 \\
0 \\
0 \\
0 \\
0 \\
\\
\end{array}$ & 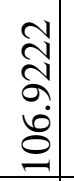 & $\begin{array}{l}2 \\
2 \\
\\
\\
\end{array}$ & 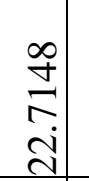 & $\begin{array}{l}\hat{\sigma} \\
\infty \\
\infty \\
\text { Na } \\
\text { Nి}\end{array}$ & $\begin{array}{l}0 \\
\\
5 \\
\infty \\
\dot{n} \\
n\end{array}$ & $\begin{array}{l}\stackrel{\nabla}{\sigma} \\
\stackrel{\sigma}{\sigma}\end{array}$ & $\begin{array}{l}a \\
\text { a } \\
\text { ñ. } \\
\text { ñ }\end{array}$ \\
\hline $\mathrm{L}$ & $\begin{array}{l}n \\
\tilde{\delta} \\
\infty \\
\text { บे } \\
\dot{J}\end{array}$ & 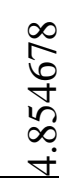 & 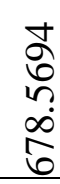 & $\begin{array}{l}\bar{n} \\
\infty \\
\dot{\Xi}\end{array}$ & 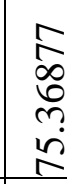 & $\begin{array}{l}\bar{\Xi} \\
\sigma \\
\dot{\sigma} \\
\bar{v}\end{array}$ & 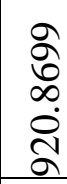 & \begin{tabular}{l}
$\infty$ \\
\multirow{+}{+}{} \\
? \\
\multirow{J}{*}{}
\end{tabular} & $\begin{array}{c}\infty \\
\infty \\
\infty \\
\dot{\sigma} \\
0\end{array}$ & 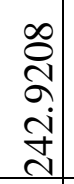 & 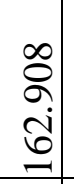 & $\begin{array}{l}\hat{n} \\
a \\
\text { d. } \\
\text { ते }\end{array}$ & $\begin{array}{l}n \\
6 \\
\infty \\
\infty \\
0 \\
\tilde{c}\end{array}$ & $\begin{array}{c}\infty \\
0 \\
5 \\
0 \\
\infty \\
0\end{array}$ & 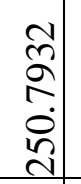 & 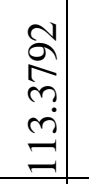 & $\begin{array}{l}m \\
0 \\
8 \\
\vdots \\
0 \\
\vdots\end{array}$ & $\begin{array}{c}8 \\
\delta \\
\\
\infty \\
0 \\
\dot{0}\end{array}$ & 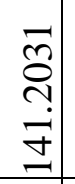 & $\begin{array}{l}\stackrel{\infty}{\circ} \\
\stackrel{n}{a} \\
\stackrel{m}{+}\end{array}$ \\
\hline M & 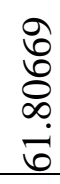 & 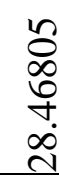 & $\begin{array}{l}\frac{m}{3} \\
\stackrel{0}{0} \\
\stackrel{2}{2}\end{array}$ & 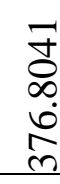 & $\begin{array}{l}2 \\
\sqrt{6} \\
i \\
n \\
n\end{array}$ & 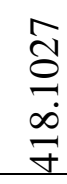 & 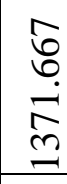 & 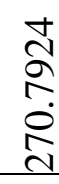 & 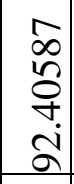 & 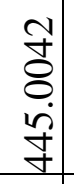 & 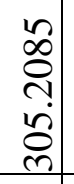 & 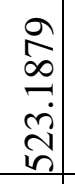 & 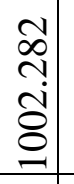 & $\begin{array}{l}8 \\
\hat{\sigma} \\
\hat{\sigma} \\
\text { i. } \\
0 \\
\end{array}$ & $\begin{array}{c}0 \\
\infty \\
\infty \\
0 \\
\dot{J} \\
\Xi\end{array}$ & 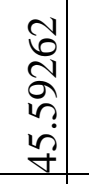 & $\begin{array}{l}a \\
a \\
\sigma \\
\dot{a}\end{array}$ & $\begin{array}{c}7 \\
7 \\
6 \\
+ \\
\dot{y} \\
\dot{y}\end{array}$ & $\begin{array}{l}\underset{\Delta}{\Delta} \\
\stackrel{\Delta}{ \pm} \\
\end{array}$ & 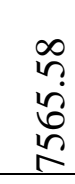 \\
\hline $\mathrm{N}$ & \begin{tabular}{l}
7 \\
\multirow{J}{J}{} \\
$\sigma$ \\
$\infty$ \\
$m$
\end{tabular} & 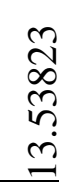 & $\frac{+}{n}$ & $\begin{array}{l}\text { 오 } \\
\text { న్ }\end{array}$ & 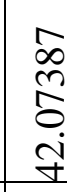 & 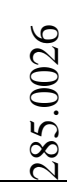 & $\begin{array}{l}\text { on } \\
\text { ñ } \\
\text { g̊ }\end{array}$ & 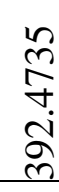 & $\begin{array}{l}\vec{N} \\
\tilde{N} \\
0 \\
= \\
=\end{array}$ & $\begin{array}{c}\forall \\
\tilde{n} \\
\infty \\
0 \\
0 \\
\infty \\
\end{array}$ & 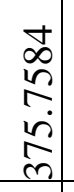 & $\begin{array}{l}\stackrel{N}{\Omega} \\
\\
\stackrel{2}{2}\end{array}$ & 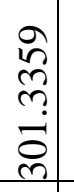 & 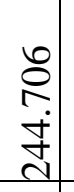 & 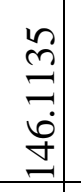 & 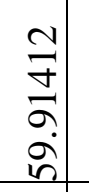 & $\begin{array}{c}\hat{\delta} \\
\tilde{n} \\
\bar{\sigma} \\
\bar{\sigma}\end{array}$ & 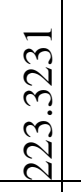 & $\begin{array}{c}a \\
m \\
m \\
n \\
n\end{array}$ & 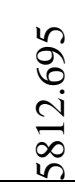 \\
\hline $\mathrm{O}$ & $\begin{array}{l}n \\
\infty \\
= \\
= \\
0 \\
n\end{array}$ & \begin{tabular}{l}
$\frac{0}{\infty}$ \\
\multirow{\sigma}{*}{} \\
$\forall$
\end{tabular} & 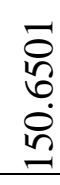 & $\begin{array}{l}\vec{\infty} \\
\stackrel{m}{ \pm} \\
\dot{m}\end{array}$ & 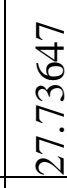 & 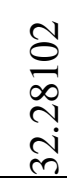 & 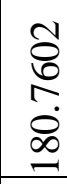 & 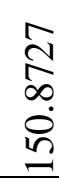 & 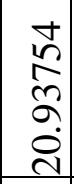 & $\begin{array}{c}\infty \\
\tilde{\sigma} \\
\stackrel{\Xi}{ \pm} \\
\dot{\sigma}\end{array}$ & 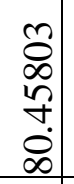 & $\begin{array}{l}\infty \\
\stackrel{n}{2} \\
\stackrel{n}{a} \\
\stackrel{n}{n}\end{array}$ & 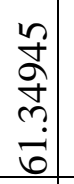 & $\begin{array}{l}\delta \\
\sigma \\
\sigma \\
\text { ஸे }\end{array}$ & 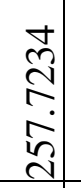 & $\begin{array}{l}n \\
\unlhd \\
\infty \\
\Xi \\
\Xi\end{array}$ & $\begin{array}{c}\hat{\infty} \\
\infty \\
\infty \\
n \\
n\end{array}$ & 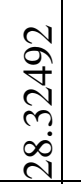 & 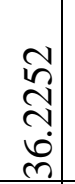 & 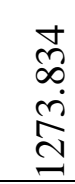 \\
\hline $\mathrm{P}$ & 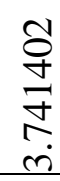 & 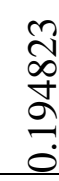 & $\begin{array}{l}\hat{\infty} \\
\text { న్ } \\
\text { ते } \\
\infty \\
n\end{array}$ & \begin{tabular}{l}
$\exists$ \\
$\vec{\infty}$ \\
\multirow{+}{+}{} \\
$\dot{+}$ \\
$\dot{n}$
\end{tabular} & $\begin{array}{l}5 \\
0 \\
\infty \\
n \\
n \\
n\end{array}$ & 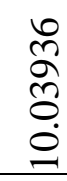 & $\begin{array}{l}\infty \\
0 \\
0 \\
0 \\
\\
\sigma\end{array}$ & 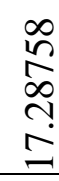 & 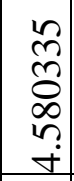 & 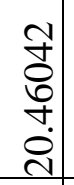 & 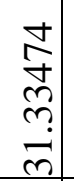 & $\begin{array}{l}0 \\
\text { గn. } \\
n \\
n \\
0 \\
0\end{array}$ & 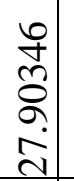 & $\begin{array}{l}n \\
8 \\
8 \\
8 \\
\end{array}$ & $\begin{array}{l}\hat{\infty} \\
\infty \\
\infty \\
\tilde{\sigma} \\
\vdots\end{array}$ & 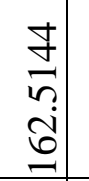 & 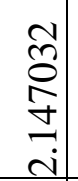 & 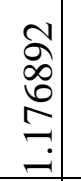 & 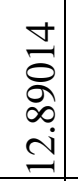 & $\begin{array}{l}\hat{\infty} \\
\hat{\infty} \\
\sigma \\
\dot{f}\end{array}$ \\
\hline $\mathrm{Q}$ & $\begin{array}{l}\bar{\sigma} \\
\hat{n} \\
6 \\
0 \\
0\end{array}$ & \begin{tabular}{l}
\multirow{N}{N}{} \\
\multirow{2}{*}{} \\
0
\end{tabular} & 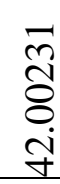 & 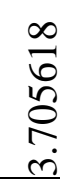 & 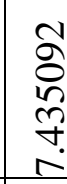 & $\begin{array}{l}\infty \\
\infty \\
\infty \\
\infty \\
\infty \\
0 \\
\dot{m} \\
\end{array}$ & \begin{tabular}{l} 
J \\
J \\
\multirow{2}{*}{} \\
त
\end{tabular} & 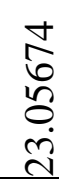 & $\begin{array}{l} \pm \\
\sigma \\
\grave{\Xi}\end{array}$ & $\begin{array}{l}\text { సે } \\
\text { సે } \\
\text { ๙ે}\end{array}$ & $\begin{array}{l}\tilde{O} \\
\infty \\
\tilde{y} \\
\tilde{y} \\
\tilde{m} \\
\tilde{m}\end{array}$ & $\begin{array}{l}0 \\
\infty \\
0 \\
0 \\
\overrightarrow{0} \\
\end{array}$ & 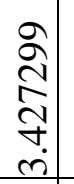 & 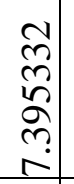 & 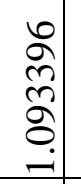 & 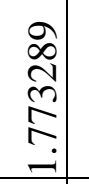 & 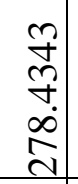 & $\begin{array}{l}n \\
n \\
0 \\
n \\
i\end{array}$ & \begin{tabular}{l}
\multirow{J}{*}{} \\
$i$ \\
$\infty$ \\
0 \\
0 \\
0
\end{tabular} & 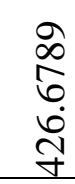 \\
\hline $\mathrm{R}$ & $\frac{\infty}{\pi}$ & 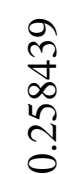 & \begin{tabular}{l}
2 \\
$\infty$ \\
$\infty$ \\
$\infty$ \\
\multirow{2}{*}{} \\
$\dot{n}$
\end{tabular} & 8 & $\frac{\text { t }}{\stackrel{2}{0}}$ & 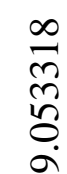 & $\begin{array}{l}\hat{n} \\
\text { d } \\
\text { ñ } \\
\text { m. }\end{array}$ & 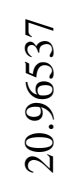 & $\begin{array}{c}a \\
\tilde{n} \\
n \\
n \\
n \\
0\end{array}$ & $\begin{array}{c}0 \\
⿱ \\
\infty \\
\infty \\
i \\
\tilde{n}\end{array}$ & 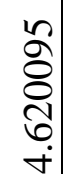 & $\begin{array}{c}m \\
0 \\
0 \\
\infty \\
0 \\
0\end{array}$ & $\begin{array}{l}n \\
\tilde{n} \\
0 \\
n\end{array}$ & 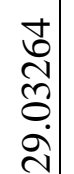 & $\begin{array}{l}\hat{n} \\
\alpha \\
\hat{\sigma} \\
\infty \\
\dot{0}\end{array}$ & $\begin{array}{c}\stackrel{m}{+} \\
\stackrel{\sim}{2} \\
\stackrel{f}{f} \\
\dot{0}\end{array}$ & $\begin{array}{l}n \\
\tilde{n} \\
\infty \\
\\
\sigma\end{array}$ & $\begin{array}{l}n \\
8 \\
\delta \\
\tilde{n}\end{array}$ & $\begin{array}{l}n \\
n \\
\delta \\
8 \\
0\end{array}$ & 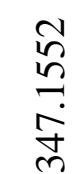 \\
\hline
\end{tabular}




\begin{tabular}{|c|c|c|c|c|c|c|c|c|c|c|c|c|c|c|c|c|c|c|c|c|}
\hline $\begin{array}{l}\mathrm{O} \\
\mathrm{d} \\
\mathrm{e}\end{array}$ & A & B & C & D & $\mathrm{E}$ & $\mathrm{F}$ & $\mathrm{G}$ & $\mathrm{H}$ & I & $\mathbf{J}$ & K & $\mathrm{L}$ & $\mathrm{M}$ & $\mathrm{N}$ & $\mathrm{O}$ & $P$ & Q & $\mathrm{R}$ & . & $\begin{array}{l}\mathrm{T} \\
\mathrm{O} \\
\mathrm{T} \\
\mathrm{A} \\
\mathrm{L}\end{array}$ \\
\hline$S$ & $\begin{array}{l}\bar{\sigma} \\
\cdots \\
\end{array}$ & 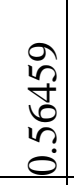 & $\begin{array}{c}\infty \\
\stackrel{2}{+} \\
\stackrel{+}{+} \\
\stackrel{+}{+} \\
\end{array}$ & 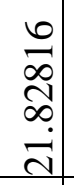 & 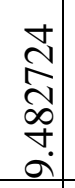 & 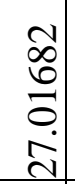 & 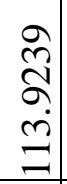 & $\begin{array}{c} \pm \\
\infty \\
\infty \\
⿱ 亠 乂 \\
\infty \\
\infty\end{array}$ & $\begin{array}{l}n \\
\hat{n} \\
n \\
\infty \\
\hat{v}\end{array}$ & 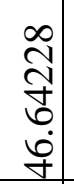 & $\begin{array}{l}\infty \\
\infty \\
5 \\
\infty \\
\dot{m} \\
\end{array}$ & 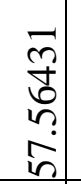 & 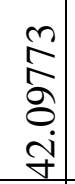 & $\begin{array}{c} \pm \\
\tilde{n} \\
\tilde{\sigma} \\
\tilde{n}\end{array}$ & $\begin{array}{l}2 \\
2 \\
\\
2 \\
2\end{array}$ & 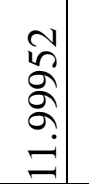 & 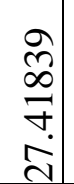 & 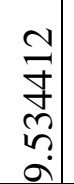 & $\begin{array}{c}m \\
\stackrel{n}{+} \\
\tilde{n} \\
=\end{array}$ & 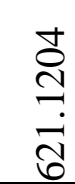 \\
\hline $\begin{array}{l}\mathrm{T} \\
\mathrm{O} \\
\mathrm{T} \\
\mathrm{A} \\
\mathrm{L}\end{array}$ & 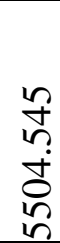 & $\begin{array}{l}t \\
n \\
0 \\
0 \\
n \\
m\end{array}$ & $\begin{array}{l}\bar{n} \\
\dot{8} \\
\Omega \\
\check{6}\end{array}$ & 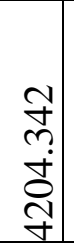 & $\begin{array}{l}0 \\
2 \\
\\
8 \\
\delta\end{array}$ & $\begin{array}{l}\hat{\sigma} \\
\hat{\sigma} \\
\end{array}$ & 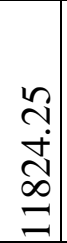 & 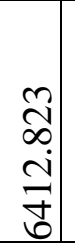 & 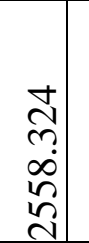 & $\begin{array}{c}0 \\
0 \\
0 \\
\infty \\
0 \\
n \\
n \\
m\end{array}$ & $\begin{array}{c}\mathfrak{\gamma} \\
\delta \\
\text { di } \\
\delta \\
\tilde{n}\end{array}$ & $\begin{array}{c}\bar{\infty} \\
= \\
\bar{\sigma} \\
\infty \\
+\end{array}$ & 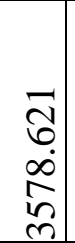 & 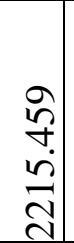 & 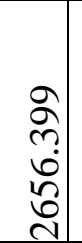 & 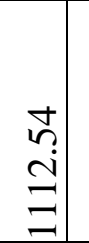 & 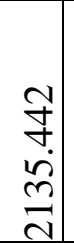 & $\begin{array}{c}0 \\
8 \\
0 \\
2 \\
\infty \\
\infty\end{array}$ & $\begin{array}{c}\tilde{n} \\
0 \\
2 \\
0 \\
0\end{array}$ & 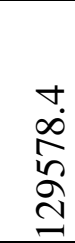 \\
\hline
\end{tabular}

11.2 Table-2 Input Coefficient Table

\begin{tabular}{|c|c|c|c|c|c|c|c|c|c|c|c|c|c|c|c|c|c|c|c|}
\hline $\begin{array}{l}\mathrm{O} \\
\mathrm{d}\end{array}$ & A & B & $\mathrm{C}$ & D & $\mathrm{E}$ & $\mathrm{F}$ & $\mathrm{G}$ & $\mathrm{H}$ & I & $\mathrm{J}$ & $\mathrm{K}$ & $\mathrm{L}$ & $\mathrm{M}$ & $\mathrm{N}$ & $\mathrm{O}$ & $\mathrm{P}$ & Q & $\mathrm{R}$ & $S$ \\
\hline A & 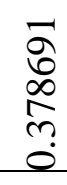 & 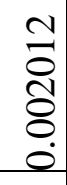 & $\begin{array}{l}\Omega \\
\text { ర్ } \\
0 \\
0 \\
0\end{array}$ & $\begin{array}{l}0 \\
\\
\vdots \\
0 \\
0\end{array}$ & $\begin{array}{l}2 \\
\hat{0} \\
8 \\
8 \\
0 \\
0\end{array}$ & $\begin{array}{l}0 \\
0 \\
0 \\
8 \\
8 \\
0\end{array}$ & 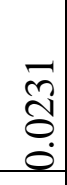 & 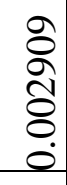 & $\begin{array}{l}\stackrel{N}{\hat{N}} \\
\stackrel{+}{0} \\
\dot{0}\end{array}$ & 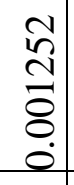 & $\begin{array}{l}\frac{1}{8} \\
8 \\
8 \\
0 \\
0\end{array}$ & $\begin{array}{l}\bar{D} \\
0 \\
0 \\
8 \\
8 \\
0\end{array}$ & $\begin{array}{l}\hat{n} \\
\delta \\
\mathscr{8} \\
\delta \\
0 \\
0\end{array}$ & 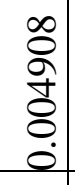 & 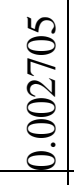 & 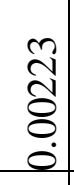 & 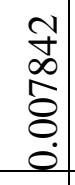 & 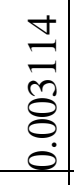 & 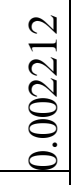 \\
\hline B & 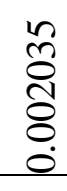 & 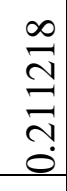 & $\begin{array}{l}\pi \\
n \\
n \\
0 \\
0\end{array}$ & $\begin{array}{l}\overline{0} \\
\bar{\sigma} \\
0 \\
0\end{array}$ & 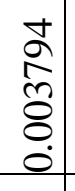 & 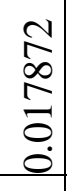 & $\begin{array}{l}m \\
0 \\
8 \\
8 \\
0\end{array}$ & 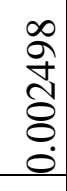 & $\begin{array}{l}\vec{J} \\
\stackrel{+}{8} \\
8 \\
0\end{array}$ & 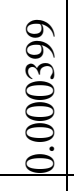 & $\begin{array}{l}0 \\
8 \\
8 \\
8 \\
8 \\
0 \\
0\end{array}$ & 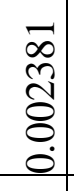 & 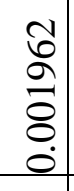 & $\begin{array}{l}\bar{\infty} \\
\stackrel{+}{+} \\
\\
\dot{8}\end{array}$ & 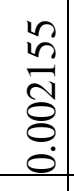 & 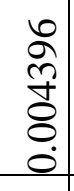 & 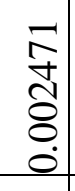 & \begin{tabular}{l}
$n$ \\
\multirow{J}{\Xi}{} \\
$\bar{\Xi}$ \\
$\dot{0}$
\end{tabular} & $\begin{array}{l}n \\
\frac{n}{\sigma} \\
\frac{8}{8} \\
\dot{0}\end{array}$ \\
\hline $\mathrm{C}$ & 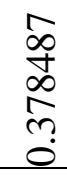 & $\begin{array}{c}\Gamma \\
\hat{0} \\
\infty \\
0 \\
? \\
0\end{array}$ & 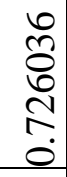 & 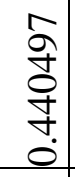 & 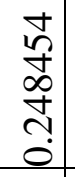 & $\begin{array}{l}\infty \\
+ \\
n \\
n \\
n \\
0\end{array}$ & 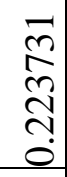 & 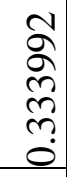 & $\begin{array}{l}\overrightarrow{7} \\
\overline{8} \\
\stackrel{0}{f} \\
\dot{0}\end{array}$ & $\begin{array}{c}0 \\
+ \\
\infty \\
\overrightarrow{0}\end{array}$ & $\begin{array}{l}n \\
\tilde{0} \\
\text { బ} \\
0 \\
0 \\
0\end{array}$ & 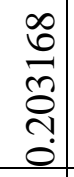 & $\begin{array}{l}\infty \\
\infty \\
n \\
\tilde{n} \\
0 \\
\vdots \\
0\end{array}$ & 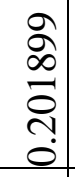 & 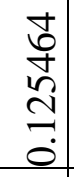 & $\begin{array}{c}N \\
\mathfrak{d} \\
0 \\
0 \\
0\end{array}$ & 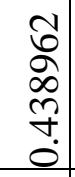 & 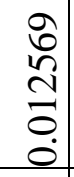 & $\begin{array}{l}\infty \\
\stackrel{0}{n} \\
\infty \\
0\end{array}$ \\
\hline D & $\begin{array}{l}\hat{\infty} \\
0 \\
+ \\
0 \\
0 \\
0\end{array}$ & 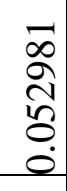 & $\begin{array}{l}\bar{a} \\
\infty \\
\infty \\
\mathbb{1} \\
0 \\
0\end{array}$ & 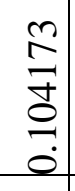 & 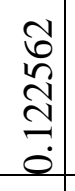 & $\begin{array}{l}\sigma \\
\sigma \\
\bar{\Xi} \\
0 \\
0\end{array}$ & 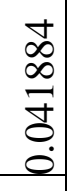 & $\begin{array}{l} \pm \\
0 \\
n \\
0 \\
0 \\
0\end{array}$ & 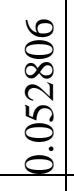 & 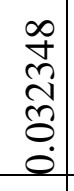 & $\begin{array}{l}0 \\
\underset{J}{J} \\
\stackrel{+}{0} \\
\dot{0}\end{array}$ & 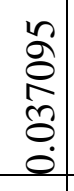 & 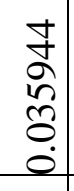 & 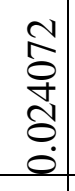 & 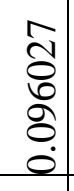 & 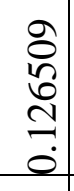 & 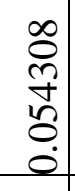 & $\begin{array}{c}5 \\
8 \\
\infty \\
0 \\
\vdots \\
0\end{array}$ & 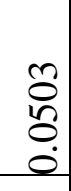 \\
\hline $\mathrm{E}$ & 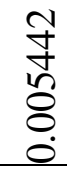 & $\begin{array}{l}\overline{0} \\
\text { o } \\
8 \\
8 \\
0 \\
0\end{array}$ & 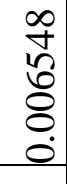 & $\begin{array}{l}n \\
8 \\
8 \\
8 \\
8 \\
0 \\
0\end{array}$ & $\begin{array}{l}2 \\
2 \\
\stackrel{2}{2} \\
\dot{0}\end{array}$ & $\begin{array}{l}n \\
2 \\
n \\
\delta \\
8 \\
0\end{array}$ & $\begin{array}{l}0 \\
2 \\
2 \\
0 \\
0 \\
0\end{array}$ & 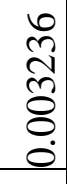 & 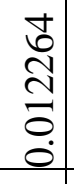 & 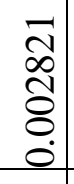 & 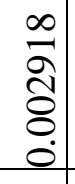 & $\begin{array}{l}\overline{8} \\
0 \\
0 \\
0 \\
0\end{array}$ & $\begin{array}{l}\$ \\
0 \\
0 \\
8 \\
8 \\
0 \\
0\end{array}$ & $\begin{array}{l}1 \\
\infty \\
0 \\
0 \\
0 \\
0 \\
0\end{array}$ & 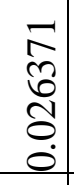 & 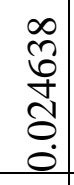 & 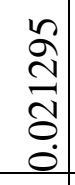 & $\begin{array}{l}2 \\
\infty \\
\infty \\
0 \\
\dot{0} \\
\dot{0}\end{array}$ & $\frac{\sqrt{0}}{0}$ \\
\hline$F$ & $\begin{array}{l}\text { n̊ } \\
\text { ๙ิ } \\
\delta \\
\delta\end{array}$ & $\begin{array}{l}+ \\
0 \\
0 \\
0 \\
0\end{array}$ & $\begin{array}{l}\hat{\sigma} \\
\tilde{n} \\
8 \\
0\end{array}$ & 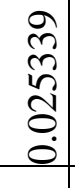 & 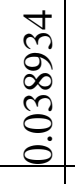 & $\begin{array}{l}+ \\
\hat{2} \\
\hat{\sigma} \\
0 \\
0\end{array}$ & $\begin{array}{l}n \\
n \\
0 \\
0 \\
0 \\
0\end{array}$ & 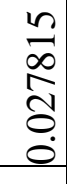 & $\begin{array}{l}0 \\
0 \\
\infty \\
8 \\
8 \\
0\end{array}$ & 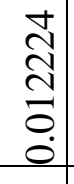 & $\begin{array}{l}\overrightarrow{\widehat{\sigma}} \\
\text { } \\
8 \\
0 \\
0\end{array}$ & $\begin{array}{c}\widetilde{b} \\
\infty \\
\widetilde{U} \\
0 \\
\dot{0}\end{array}$ & $\begin{array}{l}0 \\
0 \\
2 \\
0 \\
0 \\
0\end{array}$ & $\begin{array}{l}\infty \\
\tilde{2} \\
\grave{\delta} \\
\dot{\delta} \\
0\end{array}$ & 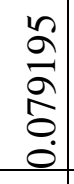 & $\begin{array}{l}\vec{J} \\
0 \\
0 \\
\dot{+} \\
0\end{array}$ & $\begin{array}{l}\bar{\sigma} \\
\bar{\sigma} \\
0 \\
0\end{array}$ & \begin{tabular}{l}
\multirow{J}{J}{} \\
$\stackrel{0}{0}$ \\
$\stackrel{0}{0}$
\end{tabular} & 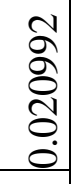 \\
\hline $\mathrm{G}$ & $\begin{array}{l}\hat{a} \\
\hat{\sigma} \\
\text { ó } \\
\dot{0}\end{array}$ & $\begin{array}{l}n \\
\infty \\
\infty \\
\infty \\
\wp \\
0 \\
0\end{array}$ & 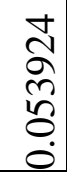 & 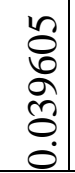 & 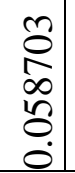 & 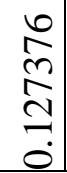 & 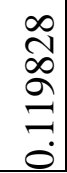 & 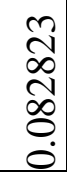 & \begin{tabular}{l}
0 \\
\multirow{+}{0}{} \\
$\infty$ \\
0 \\
0 \\
0
\end{tabular} & 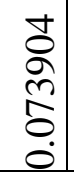 & 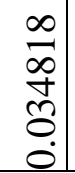 & $\begin{array}{l}\infty \\
2 \\
2 \\
0 \\
0 \\
0 \\
0\end{array}$ & 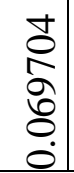 & $\frac{7}{8}$ & $\begin{array}{c}0 \\
i n \\
\frac{n}{0} \\
0 \\
0\end{array}$ & 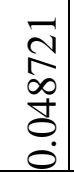 & \begin{tabular}{c}
$\mathcal{N}$ \\
\multirow{J}{\infty}{} \\
0 \\
0
\end{tabular} & 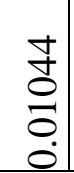 & $\begin{array}{l}0 \\
\infty \\
0 \\
0 \\
0 \\
0\end{array}$ \\
\hline
\end{tabular}




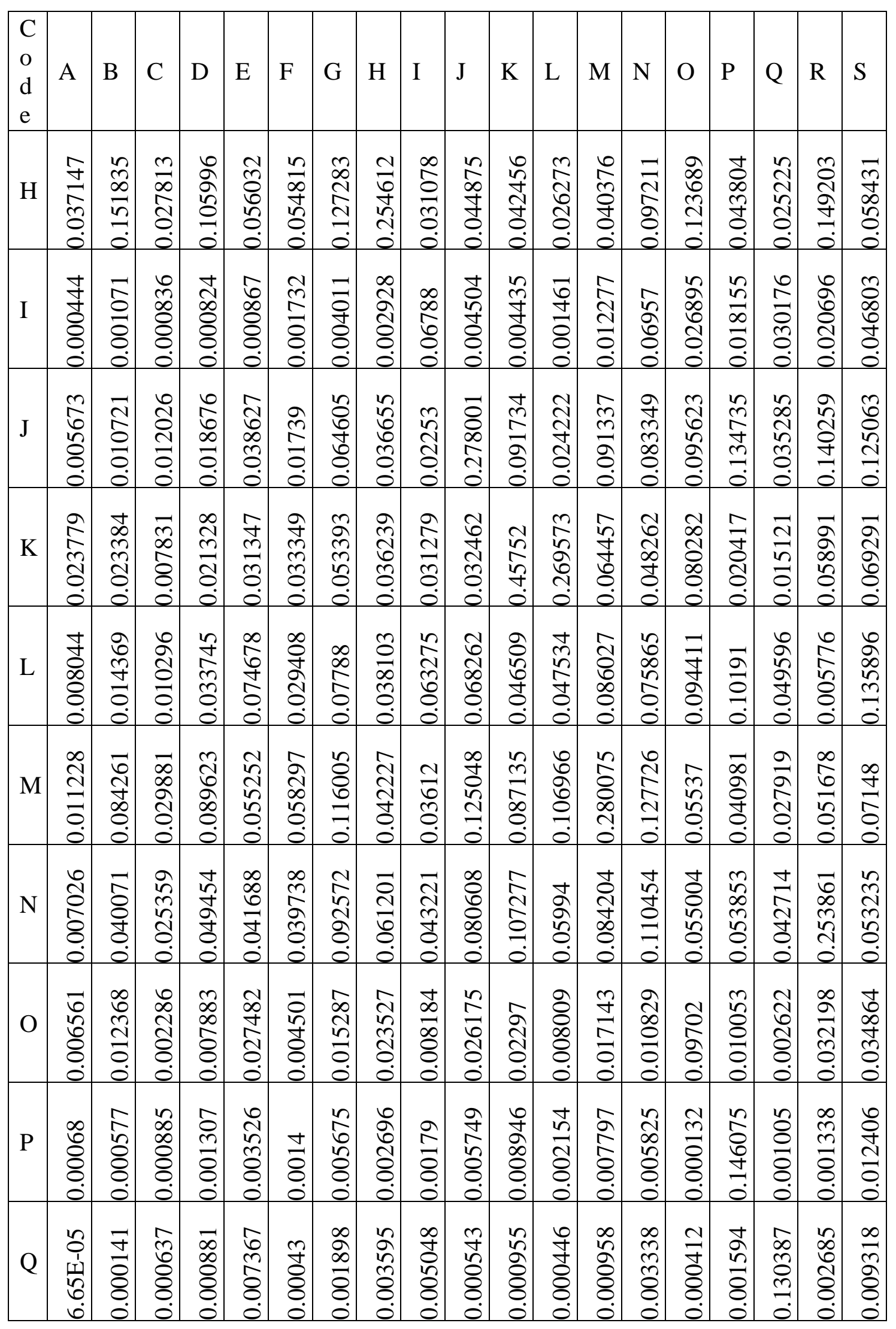




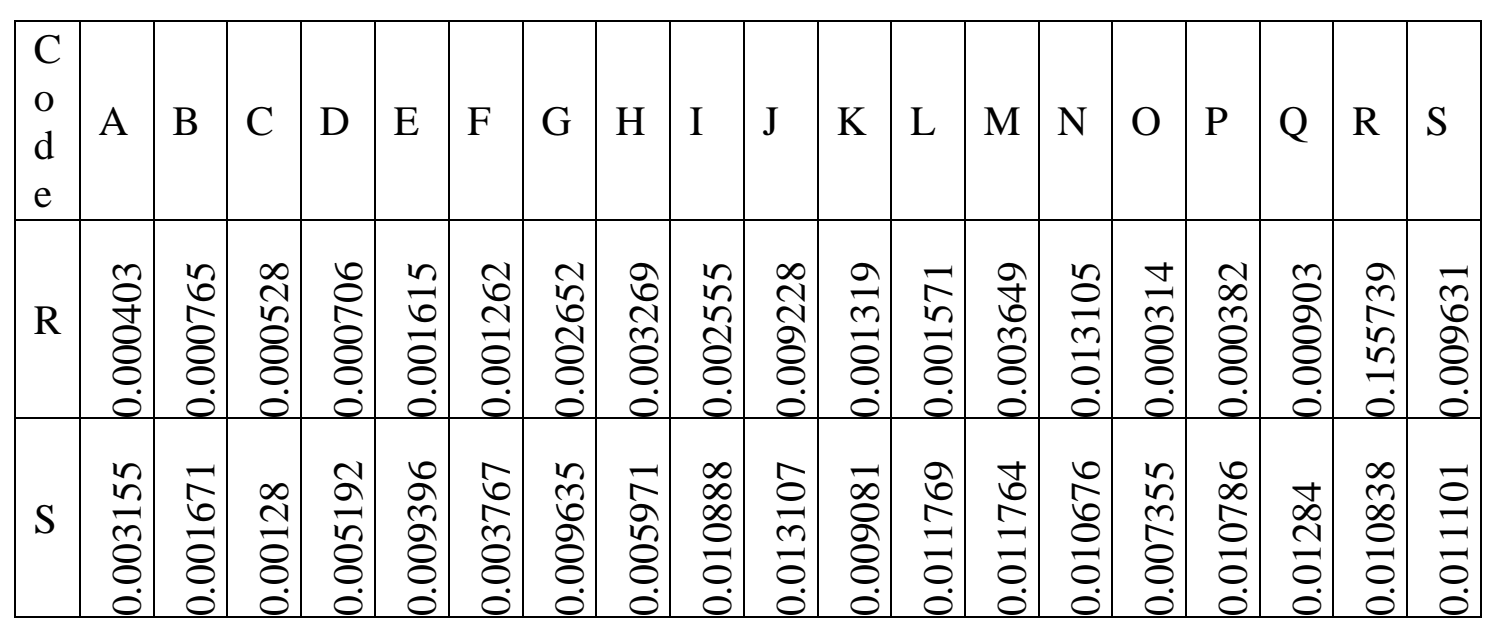

11.3 Table-3 Import Coefficient Table

\begin{tabular}{|c|c|c|c|c|c|c|c|c|c|c|c|c|c|c|c|c|c|c|c|}
\hline $\begin{array}{l}\mathrm{C} \\
\mathrm{od} \\
\mathrm{e}\end{array}$ & A & B & $\mathrm{C}$ & D & $E$ & $\mathrm{~F}$ & $\mathrm{G}$ & $\mathrm{H}$ & I & $\mathbf{J}$ & K & $\mathrm{L}$ & $\mathrm{M}$ & $\mathrm{N}$ & $\mathrm{O}$ & $\mathrm{P}$ & Q & $\mathrm{R}$ & $S$ \\
\hline A & 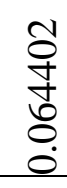 & $\begin{array}{l}\stackrel{m}{ٍ} \\
\overline{8} \\
0\end{array}$ & \begin{tabular}{l}
\multirow{2}{*}{} \\
$\infty$ \\
$\infty$ \\
$\infty$ \\
0 \\
0 \\
0
\end{tabular} & $\begin{array}{l}n \\
\stackrel{n}{n} \\
\delta \\
8 \\
0\end{array}$ & $\begin{array}{l}\frac{9}{2} \\
\frac{1}{8} \\
0\end{array}$ & $\begin{array}{l}\bar{\sigma} \\
\text { ปे } \\
\delta \\
\delta \\
0\end{array}$ & $\begin{array}{l}\hat{n} \\
\hat{\sigma} \\
0 \\
0\end{array}$ & $\begin{array}{l}\stackrel{+}{n} \\
\stackrel{2}{0} \\
8 \\
0\end{array}$ & $\begin{array}{l}\infty \\
\infty \\
\infty \\
\approx \\
0 \\
0 \\
0\end{array}$ & $\begin{array}{l}0 \\
8 \\
8 \\
8 \\
0\end{array}$ & 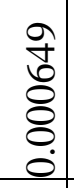 & 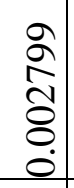 & $\begin{array}{l}\infty \\
+ \\
\infty \\
ల \\
8 \\
0 \\
0\end{array}$ & 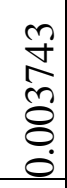 & 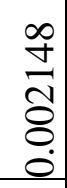 & 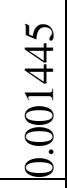 & 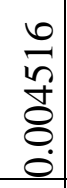 & 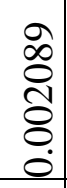 & 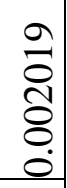 \\
\hline B & $\begin{array}{l}\bar{\sigma} \\
\bar{\Omega} \\
\delta \\
0 \\
0\end{array}$ & $\frac{\vec{J}}{\stackrel{+}{+}}$ & $\begin{array}{l}\frac{m}{6} \\
0 \\
0 \\
0\end{array}$ & $\begin{array}{l}n \\
\hat{0} \\
8 \\
0 \\
0\end{array}$ & 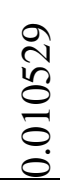 & $\begin{array}{l}\bar{\infty} \\
\stackrel{2}{1} \\
\delta \\
0 \\
0\end{array}$ & $\begin{array}{l}0 \\
\text { م } \\
\text { ஸे } \\
\delta \\
\delta \\
0\end{array}$ & \begin{tabular}{l}
$\vec{\infty}$ \\
\multirow{+}{+}{} \\
8 \\
\\
0
\end{tabular} & $\begin{array}{l}0 \\
\frac{1}{2} \\
8 \\
0 \\
0\end{array}$ & $\begin{array}{l}\hat{2} \\
8 \\
8 \\
8 \\
0\end{array}$ & $\begin{array}{l}\mathfrak{2} \\
8 \\
8 \\
8 \\
0\end{array}$ & 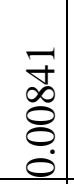 & \begin{tabular}{l}
$\overline{5}$ \\
\multirow{1}{*}{} \\
8 \\
0 \\
0
\end{tabular} & 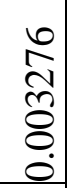 & 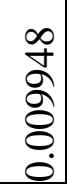 & 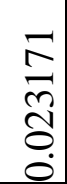 & 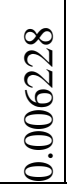 & \begin{tabular}{l}
0 \\
8 \\
\multirow{+}{+}{} \\
0 \\
0 \\
0
\end{tabular} & $\begin{array}{l}\frac{n}{6} \\
\text { है } \\
0 \\
0\end{array}$ \\
\hline $\mathrm{C}$ & $\begin{array}{l}n \\
n \\
\infty \\
n \\
+ \\
\infty \\
0\end{array}$ & 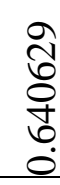 & $\begin{array}{l}0 \\
\text { N } \\
\text { స్} \\
\infty \\
\infty \\
0\end{array}$ & 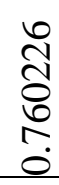 & $\begin{array}{l}n \\
n \\
\infty \\
\text { No } \\
\text { రై } \\
0\end{array}$ & $\frac{\infty}{\infty}$ & 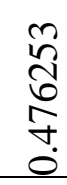 & 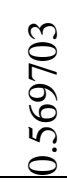 & 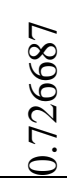 & 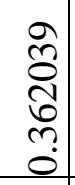 & $\frac{\sqrt{n}}{\frac{\infty}{6}}$ & $\begin{array}{l}m \\
\hat{\delta} \\
\delta \\
0 \\
0 \\
0\end{array}$ & 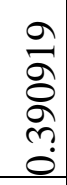 & $\begin{array}{l}2 \\
\hat{6} \\
n \\
0 \\
0\end{array}$ & 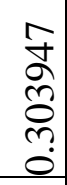 & 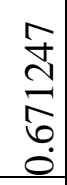 & \begin{tabular}{l}
8 \\
\multirow{0}{0}{} \\
$\infty$ \\
0 \\
0
\end{tabular} & 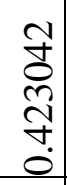 & 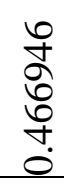 \\
\hline D & $\begin{array}{l}n \\
\tilde{\sigma} \\
\widetilde{\sigma} \\
0 \\
0\end{array}$ & 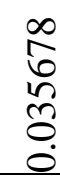 & 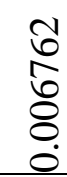 & $\begin{array}{l}\frac{m}{0} \\
\frac{0}{0} \\
0\end{array}$ & $\frac{m}{\frac{m}{n}}$ & $\begin{array}{l}\text { N } \\
\text { in } \\
\text { \& } \\
0\end{array}$ & 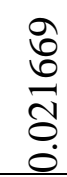 & 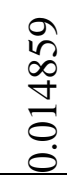 & $\begin{array}{l}\text { 志 } \\
\text { On } \\
\text { กิ } \\
0 \\
0\end{array}$ & $\begin{array}{l}\infty \\
n \\
\tilde{n} \\
\infty \\
0 \\
0 \\
0\end{array}$ & $\begin{array}{l}\sqrt{ } \\
\infty \\
0 \\
0 \\
0 \\
0\end{array}$ & $\begin{array}{l}\bar{n} \\
\hat{\sigma} \\
\text { ๙ิ } \\
0\end{array}$ & 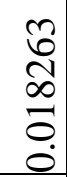 & $\begin{array}{l}\vec{N} \\
\tilde{0} \\
0 \\
0 \\
0\end{array}$ & \begin{tabular}{l}
$\tilde{\sigma}$ \\
\multirow{7}{*}{} \\
0 \\
0 \\
0
\end{tabular} & $\begin{array}{l}\sqrt{2} \\
\tilde{n} \\
\tilde{2} \\
0 \\
0\end{array}$ & $\begin{array}{l}\overline{0} \\
8 \\
+ \\
0 \\
0 \\
0\end{array}$ & 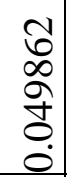 & $\begin{array}{l}\text { No } \\
\text { ñ } \\
0 \\
0 \\
0\end{array}$ \\
\hline $\mathrm{E}$ & 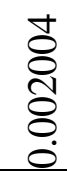 & 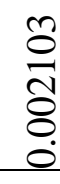 & 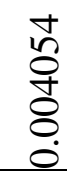 & $\frac{0}{\frac{\sigma}{+}}$ & 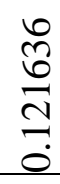 & $\begin{array}{l}\text { J } \\
0 \\
0 \\
0 \\
0 \\
0\end{array}$ & 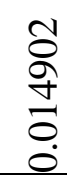 & 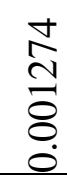 & $\begin{array}{l}\frac{n}{6} \\
\frac{0}{8} \\
0 \\
0\end{array}$ & $\begin{array}{l}n \\
6 \\
8 \\
8 \\
0\end{array}$ & $\begin{array}{l}n \\
6 \\
8 \\
8 \\
8 \\
0\end{array}$ & $\begin{array}{l}\bar{\Xi} \\
\bar{\Xi} \\
\\
0\end{array}$ & 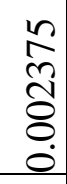 & $\begin{array}{l}n \\
6 \\
1 \\
0 \\
8 \\
0 \\
0\end{array}$ & $\begin{array}{l}0 \\
8 \\
8 \\
8 \\
8 \\
0\end{array}$ & $\begin{array}{l}n \\
\stackrel{7}{0} \\
\infty \\
8 \\
8 \\
0 \\
0\end{array}$ & 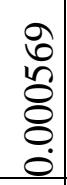 & $\begin{array}{c}\stackrel{8}{+} \\
\stackrel{+}{8} \\
\stackrel{8}{8} \\
\dot{0}\end{array}$ & 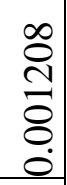 \\
\hline $\mathrm{F}$ & $\begin{array}{l}\stackrel{\infty}{+} \\
\\
0 \\
0\end{array}$ & 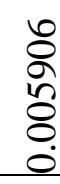 & 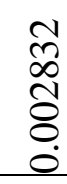 & $\begin{array}{l}\frac{ \pm}{\sigma} \\
\text { m } \\
0 \\
0\end{array}$ & \begin{tabular}{l}
$\bar{\sigma}$ \\
\multirow{+}{*}{} \\
8 \\
0
\end{tabular} & 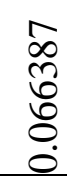 & 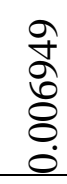 & 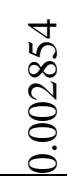 & 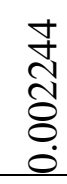 & 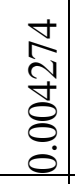 & $\begin{array}{l}\hat{\hat{S}} \\
\hat{\widehat{O}} \\
\mathbf{8} \\
\dot{0}\end{array}$ & 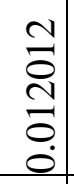 & $\begin{array}{l}0 \\
\stackrel{0}{+} \\
\Xi \\
0 \\
0\end{array}$ & $\begin{array}{l}1 \\
0 \\
0 \\
0 \\
0 \\
0\end{array}$ & $\begin{array}{l}0 \\
0 \\
\delta \\
0 \\
0\end{array}$ & 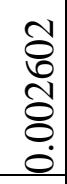 & 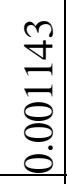 & 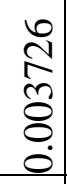 & 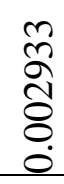 \\
\hline $\mathrm{G}$ & 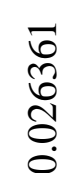 & $\begin{array}{l}\text { 궁 } \\
\stackrel{\infty}{n} \\
0 \\
0 \\
0\end{array}$ & $\begin{array}{l}\bar{\delta} \\
\stackrel{\sigma}{\sigma} \\
0 \\
0\end{array}$ & $\begin{array}{l}\sqrt{2} \\
\frac{n}{2} \\
0 \\
0\end{array}$ & $\begin{array}{l}\text { ป̂ } \\
\text { } \\
\frac{0}{0} \\
0\end{array}$ & 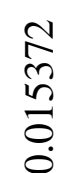 & 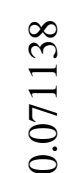 & 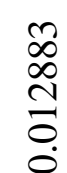 & 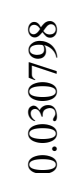 & 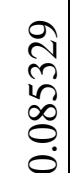 & 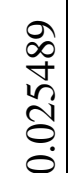 & 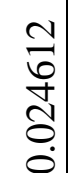 & $\begin{array}{l}n \\
n \\
\tilde{n} \\
0\end{array}$ & $\begin{array}{l}n \\
n \\
0 \\
0 \\
0 \\
0 \\
0\end{array}$ & $\begin{array}{l}\frac{a}{n} \\
\frac{n}{0} \\
0 \\
0\end{array}$ & 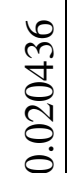 & 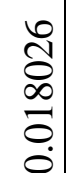 & $\begin{array}{l}\vec{N} \\
\infty \\
5 \\
0 \\
0\end{array}$ & 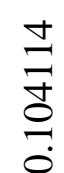 \\
\hline
\end{tabular}




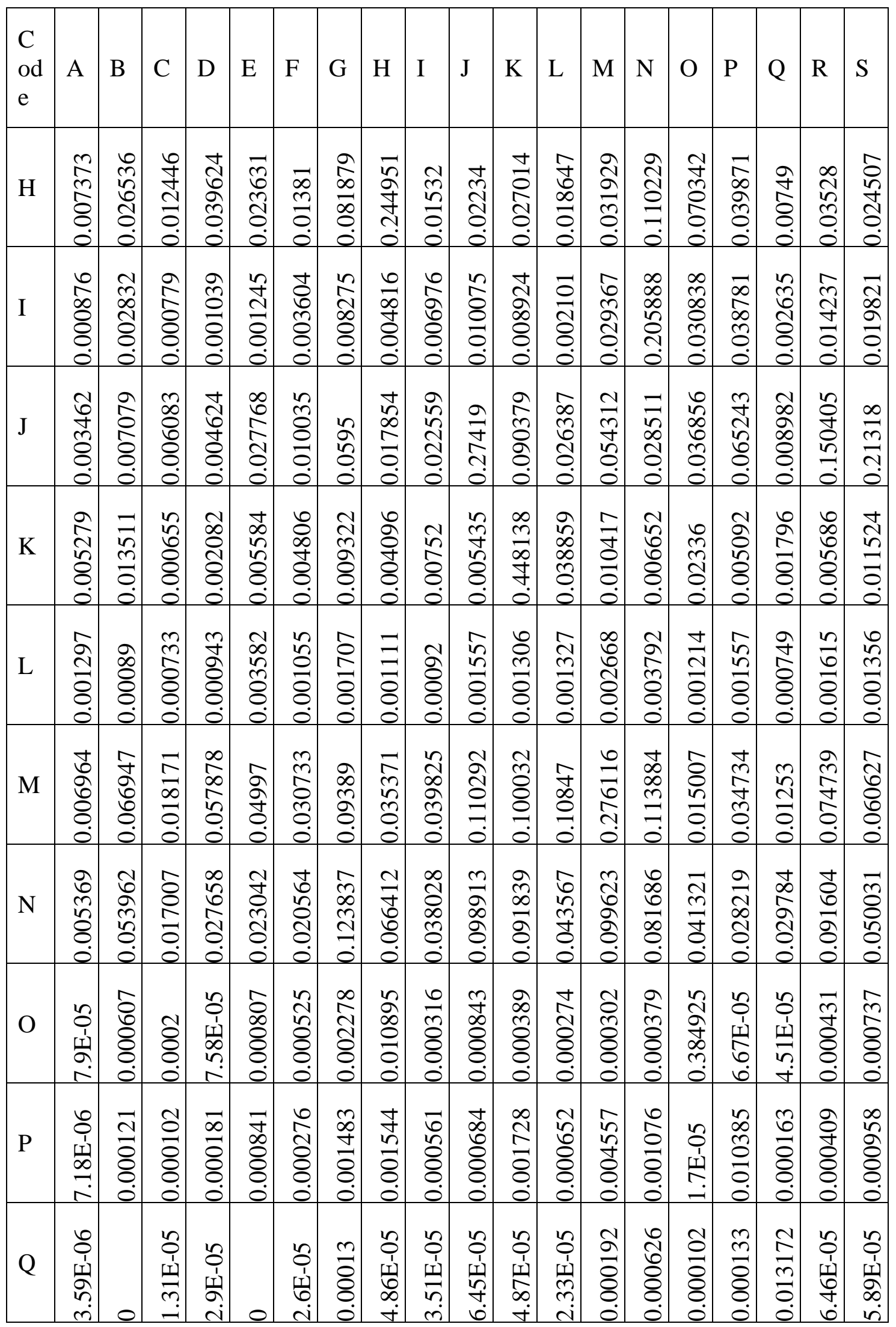




\begin{tabular}{|c|c|c|c|c|c|c|c|c|c|c|c|c|c|c|c|c|c|c|c|}
\hline $\begin{array}{l}\mathrm{C} \\
\text { od } \\
\mathrm{e}\end{array}$ & A & B & $\mathrm{C}$ & D & $\mathrm{E}$ & $\mathrm{F}$ & $\mathrm{G}$ & $\mathrm{H}$ & I & $\mathbf{J}$ & K & $\mathrm{L}$ & $\mathrm{M}$ & $\mathrm{N}$ & $\mathrm{O}$ & $\mathrm{P}$ & $\mathrm{Q}$ & $\mathrm{R}$ & $S$ \\
\hline $\mathrm{R}$ & $\begin{array}{l}n \\
0 \\
1 \\
\infty \\
\infty \\
\end{array}$ & $\begin{array}{l}\overline{1} \\
\overline{8} \\
8 \\
0\end{array}$ & $\begin{array}{l}\text { ㄱ. } \\
\\
8 \\
8 \\
0\end{array}$ & 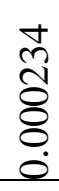 & $\begin{array}{l}\infty \\
0 \\
0 \\
8 \\
8 \\
0\end{array}$ & 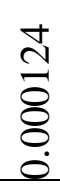 & $\begin{array}{l}\text { J } \\
\frac{0}{8} \\
0 \\
0\end{array}$ & $\begin{array}{l}\infty \\
\tilde{n} \\
\tilde{8} \\
\delta \\
0 \\
0\end{array}$ & $\begin{array}{l}\text { ป } \\
\Xi \\
8 \\
8 \\
0\end{array}$ & $\begin{array}{l}0 \\
\infty \\
8 \\
8 \\
0 \\
0\end{array}$ & $\begin{array}{l}\widehat{O} \\
\infty \\
8 \\
8 \\
0 \\
0\end{array}$ & 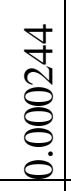 & 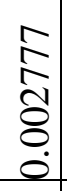 & 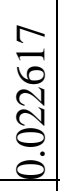 & 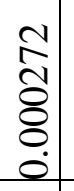 & $\begin{array}{l}0 \\
\swarrow \\
\approx \\
8 \\
8 \\
0 \\
0\end{array}$ & $\begin{array}{c}8 \\
0 \\
8 \\
8 \\
0 \\
0\end{array}$ & 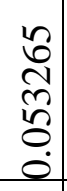 & 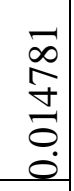 \\
\hline$S$ & 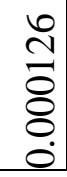 & $\begin{array}{l}\frac{ \pm}{2} \\
\frac{8}{8} \\
0\end{array}$ & 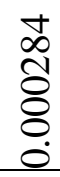 & $\begin{array}{l}\frac{9}{8} \\
8 \\
8\end{array}$ & 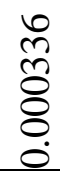 & 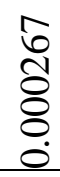 & 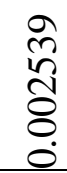 & $\begin{array}{l}\frac{ \pm}{\nabla} \\
\overline{8} \\
\dot{0}\end{array}$ & $\begin{array}{l}\frac{n}{5} \\
\frac{7}{8} \\
8 \\
0 \\
0\end{array}$ & 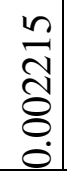 & 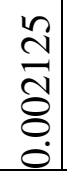 & $\begin{array}{l}\text { శ̊ } \\
\text { } \\
8 \\
8 \\
8 \\
\dot{0}\end{array}$ & 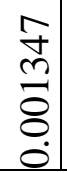 & $\begin{array}{l}\hat{a} \\
\tilde{n} \\
\overline{8} \\
0 \\
0\end{array}$ & $\begin{array}{l}\infty \\
0 \\
8 \\
8 \\
8 \\
8 \\
0\end{array}$ & 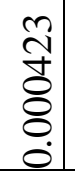 & 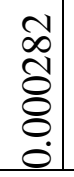 & 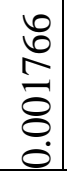 & $\begin{array}{l}n \\
\stackrel{n}{1} \\
\frac{8}{8} \\
0\end{array}$ \\
\hline
\end{tabular}

11.4 Table-4 Labour Coefficient Table

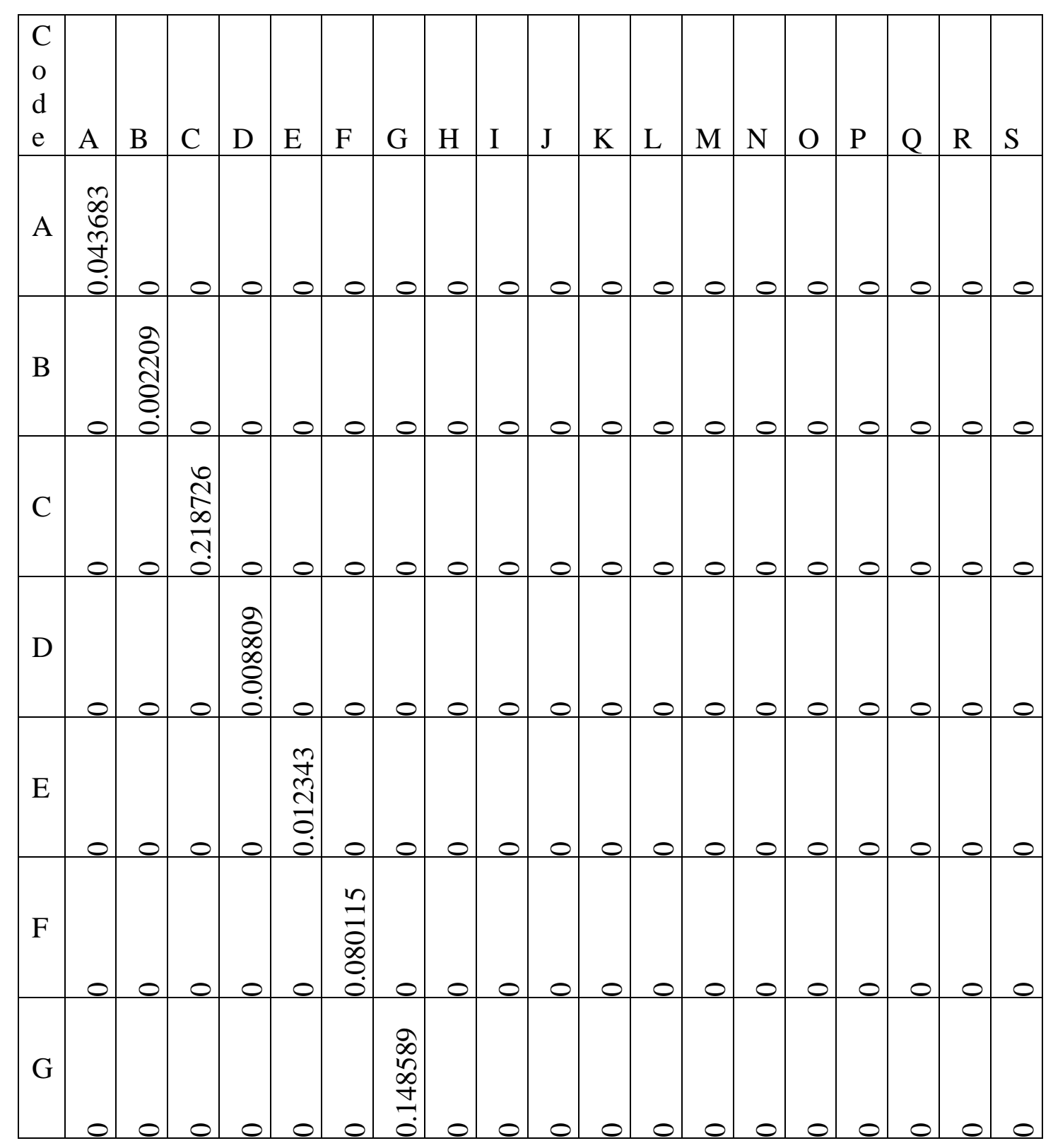




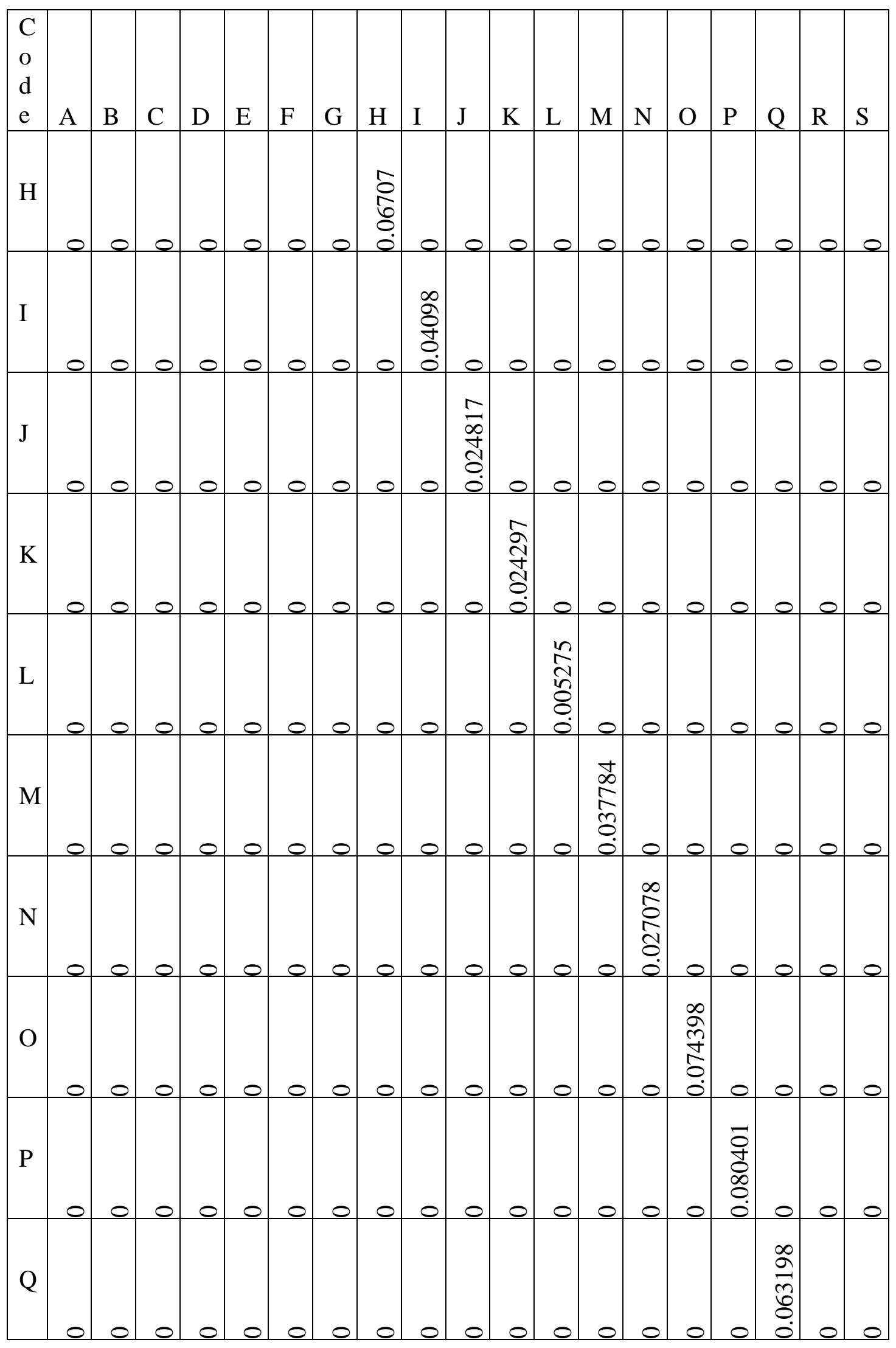




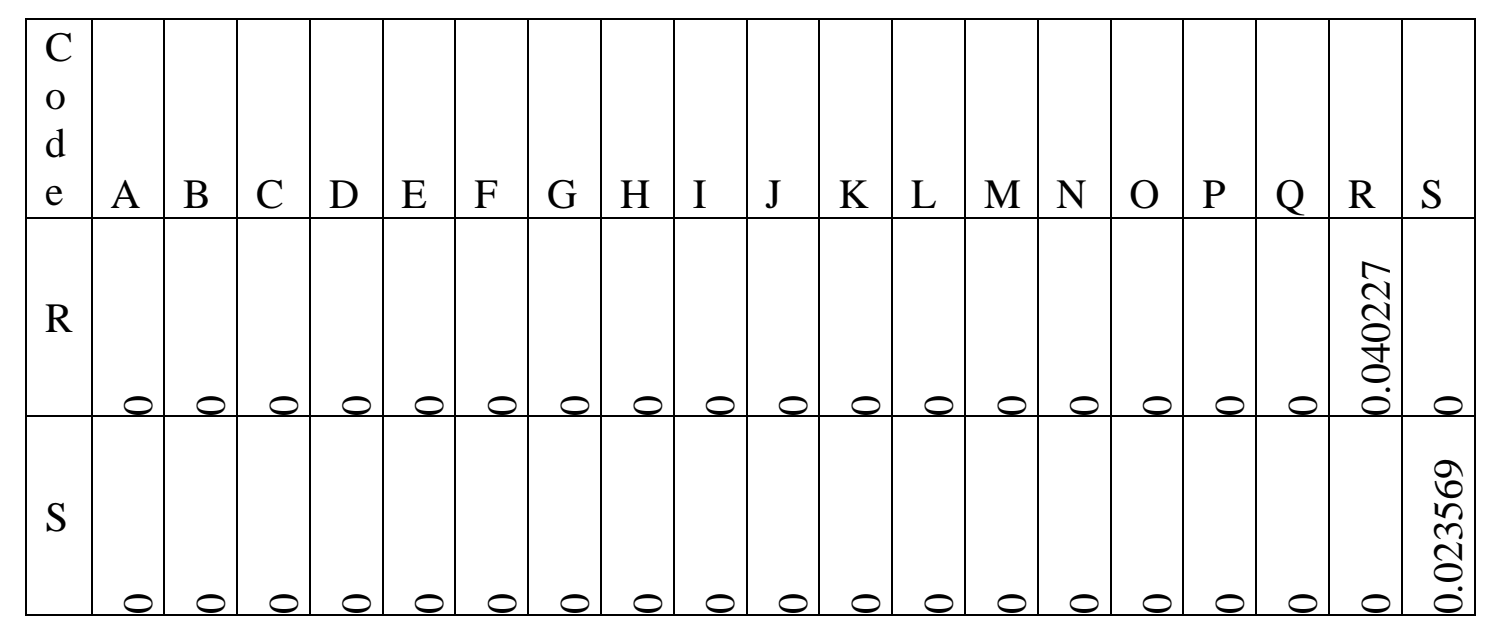

11.5 Table-5 Occupation Coefficient Table

\begin{tabular}{|c|c|c|c|c|c|c|c|c|c|c|c|c|c|c|c|c|c|c|c|}
\hline $\begin{array}{l}\mathrm{O} \\
\mathrm{d}\end{array}$ & A & B & $\mathrm{C}$ & D & $\mathrm{E}$ & $\mathrm{F}$ & $\mathrm{G}$ & $\mathrm{H}$ & I & $\mathrm{J}$ & $\mathrm{K}$ & $\mathrm{L}$ & $\mathbf{M}$ & $\mathrm{N}$ & $\mathrm{O}$ & $\mathrm{P}$ & $Q$ & $\mathrm{R}$ & $S$ \\
\hline 1 & 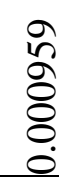 & 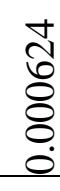 & $\begin{array}{l}2 \\
1 \\
1 \\
2 \\
\infty \\
\dot{j}\end{array}$ & $\begin{array}{l}\text { } \\
\text { } \\
8 \\
8\end{array}$ & $\begin{array}{l}\stackrel{m}{+} \\
\stackrel{+}{+} \\
8 \\
\dot{8}\end{array}$ & $\begin{array}{l}\stackrel{2}{0} \\
\text { o } \\
\stackrel{8}{0} \\
0\end{array}$ & $\begin{array}{l}\text { 응 } \\
8 \\
8 \\
8 \\
0\end{array}$ & 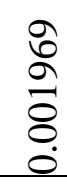 & $\begin{array}{l}0 \\
\infty \\
0 \\
0 \\
0 \\
0\end{array}$ & $\begin{array}{l}n \\
\frac{n}{2} \\
\delta \\
0\end{array}$ & 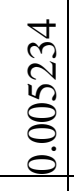 & 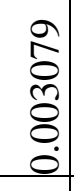 & $\begin{array}{l}\infty \\
\infty \\
+ \\
8 \\
8 \\
0\end{array}$ & $\begin{array}{l} \pm \\
\vec{J} \\
\infty \\
8 \\
\dot{0}\end{array}$ & 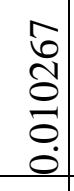 & & 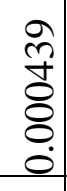 & 0 & 0 \\
\hline 2 & 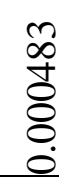 & $\begin{array}{l}n \\
\frac{n}{8} \\
8 \\
0\end{array}$ & 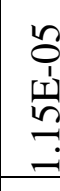 & $\begin{array}{l}0 \\
\text { Jे. } \\
8 \\
8 \\
0\end{array}$ & $\begin{array}{l}n \\
\tilde{n} \\
8 \\
0 \\
0\end{array}$ & 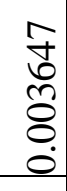 & $\begin{array}{l}\stackrel{2}{1} \\
\bar{\delta} \\
8 \\
0\end{array}$ & 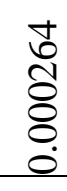 & \begin{tabular}{l}
\multirow{2}{*}{} \\
$\varnothing$ \\
$\infty$ \\
8 \\
0 \\
0
\end{tabular} & $\begin{array}{l}\widehat{\imath} \\
\delta \\
\check{\delta} \\
\delta \\
0\end{array}$ & $\begin{array}{c}\stackrel{\Xi}{N} \\
\stackrel{J}{ \pm} \\
\vdots \\
\dot{0}\end{array}$ & $\begin{array}{l}\vec{n} \\
\dot{f} \\
\check{8} \\
\dot{0} \\
\dot{0}\end{array}$ & 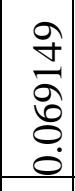 & \begin{tabular}{l}
$n$ \\
0 \\
0 \\
\multirow{2}{*}{} \\
0 \\
0
\end{tabular} & 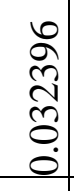 & 0 & 0 & 0 & 0 \\
\hline 3 & 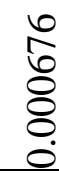 & 0 & $\begin{array}{l}n \\
0 \\
1 \\
11 \\
n \\
n\end{array}$ & $\begin{array}{l}\sqrt{n} \\
\overline{0} \\
0\end{array}$ & 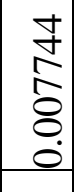 & 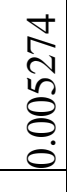 & 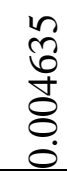 & \begin{tabular}{l}
0 \\
\multirow{J}{+}{} \\
\\
8 \\
0
\end{tabular} & 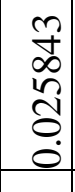 & 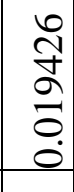 & $\begin{array}{l}0 \\
\delta \\
0 \\
0 \\
0 \\
0\end{array}$ & 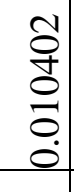 & 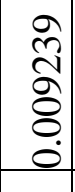 & $\begin{array}{l} \pm \\
\stackrel{0}{\infty} \\
8 \\
\dot{0} \\
0\end{array}$ & $\begin{array}{l}\overline{8} \\
0 \\
0 \\
0\end{array}$ & $\begin{array}{l}\hat{8} \\
8 \\
8 \\
0\end{array}$ & 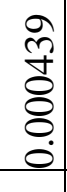 & 0 & 0 \\
\hline 4 & $\begin{array}{l}\infty \\
n \\
\swarrow \\
\delta \\
\delta \\
0\end{array}$ & $\begin{array}{l}n \\
1 \\
\underline{1} \\
\sigma \\
\end{array}$ & $\begin{array}{l}n \\
0 \\
1 \\
m \\
\infty \\
m \\
m\end{array}$ & 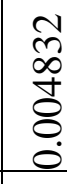 & $\begin{array}{l}0 \\
\infty \\
2 \\
\delta \\
\delta \\
0\end{array}$ & 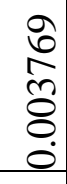 & 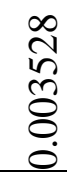 & 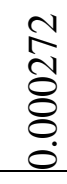 & $\begin{array}{l}2 \\
2 \\
\tilde{N} \\
0 \\
0 \\
0\end{array}$ & 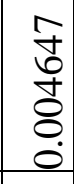 & $\begin{array}{l}8 \\
\delta \\
\infty \\
\infty \\
8 \\
0\end{array}$ & $\begin{array}{l}0 \\
8 \\
\infty \\
\text { ஸ̊ } \\
8 \\
0\end{array}$ & $\begin{array}{c}\tilde{N} \\
\infty \\
2 \\
\tilde{\delta} \\
\delta \\
0 \\
0\end{array}$ & 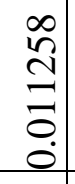 & $\begin{array}{l}0 \\
0 \\
0 \\
0 \\
0\end{array}$ & 0 & 0 & 0 & 0 \\
\hline 5 & $\begin{array}{l}8 \\
8 \\
8 \\
8 \\
8 \\
0\end{array}$ & 0 & $\begin{array}{l}n \\
0 \\
1 \\
n \\
n \\
n\end{array}$ & \begin{tabular}{l} 
¿े \\
\multirow{1}{8}{} \\
8 \\
0
\end{tabular} & 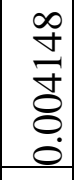 & $\begin{array}{l}2 \\
\infty \\
\stackrel{0}{8} \\
\stackrel{8}{8}\end{array}$ & 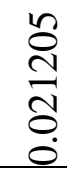 & 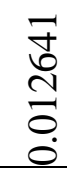 & 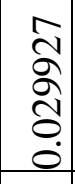 & 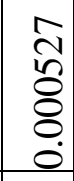 & $\begin{array}{l}\hat{\infty} \\
\hat{⿱} \\
8 \\
8 \\
0\end{array}$ & $\begin{array}{l}0 \\
0 \\
0 \\
8 \\
8 \\
0\end{array}$ & 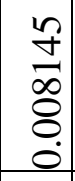 & 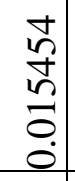 & $\begin{array}{c}\infty \\
0 \\
\infty \\
\infty \\
0 \\
0\end{array}$ & 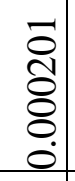 & 0 & 0 & 0 \\
\hline 6 & 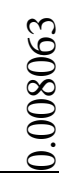 & $\begin{array}{l}\infty \\
0 \\
+ \\
\\
8 \\
0\end{array}$ & 0 & $\begin{array}{l}0 \\
0 \\
0 \\
8 \\
8 \\
8 \\
0\end{array}$ & $\begin{array}{l}2 \\
6 \\
1 \\
\frac{1}{2} \\
r \\
r\end{array}$ & $\begin{array}{l}n \\
0 \\
1 \\
n \\
6 \\
6\end{array}$ & $\begin{array}{l}n \\
o \\
1 \\
\text { ப̇ } \\
0 \\
0\end{array}$ & 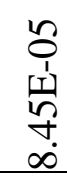 & $\begin{array}{l}\infty \\
0 \\
8 \\
8 \\
8 \\
0\end{array}$ & 0 & 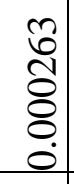 & 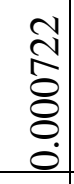 & \begin{tabular}{|}
0 \\
$\infty$ \\
8 \\
8 \\
0 \\
0
\end{tabular} & $\begin{array}{l}m \\
\tilde{n} \\
8 \\
8 \\
0 \\
0\end{array}$ & 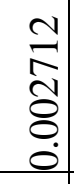 & 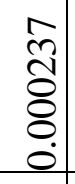 & 0 & 0 & 0 \\
\hline 7 & $\begin{array}{l}\bar{n} \\
0 \\
0\end{array}$ & $\frac{n}{8}$ & 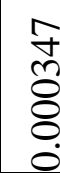 & 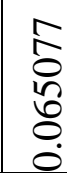 & $\begin{array}{l}\stackrel{\infty}{i n} \\
\stackrel{n}{+} \\
0 \\
0\end{array}$ & 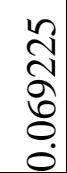 & $\begin{array}{l}\text { ले } \\
\text { గి } \\
8 \\
0\end{array}$ & 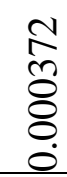 & $\left|\begin{array}{c}8 \\
8 \\
\infty \\
\infty \\
0 \\
0 \\
0\end{array}\right|$ & $\begin{array}{l}n \\
0 \\
1 \\
1 \\
7 \\
\dot{y} \\
\dot{y}\end{array}$ & 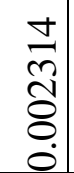 & $\begin{array}{l}8 \\
\delta \\
\delta \\
8 \\
\dot{8} \\
0\end{array}$ & $\begin{array}{l}1 \\
6 \\
21 \\
\delta \\
8 \\
0\end{array}$ & 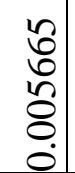 & $\begin{array}{c}0 \\
8 \\
5 \\
8 \\
8 \\
0\end{array}$ & 0 & 0 & 0 & 0 \\
\hline
\end{tabular}




\begin{tabular}{|c|c|c|c|c|c|c|c|c|c|c|c|c|c|c|c|c|c|c|c|}
\hline $\begin{array}{l}\mathrm{C} \\
\mathrm{o} \\
\mathrm{d} \\
\mathrm{e}\end{array}$ & A & B & $\mathrm{C}$ & D & $\mathrm{E}$ & $\mathrm{F}$ & $\mathrm{G}$ & $\mathrm{H}$ & I & $\mathbf{J}$ & $\mathrm{K}$ & $\mathrm{L}$ & $\mathbf{M}$ & $\mathrm{N}$ & $\mathrm{O}$ & $P$ & $\mathrm{Q}$ & $\mathrm{R}$ & $S$ \\
\hline 8 & 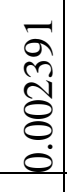 & 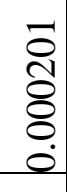 & 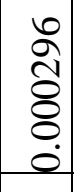 & $\begin{array}{c}\bar{b} \\
\vdots \\
\bar{n} \\
0 \\
0\end{array}$ & $\begin{array}{l}n \\
2 \\
8 \\
8 \\
0\end{array}$ & $\begin{array}{l}8 \\
8 \\
\delta \\
8 \\
0\end{array}$ & 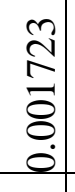 & $\begin{array}{l}\bar{m} \\
\overline{8} \\
8 \\
0 \\
0\end{array}$ & \begin{tabular}{l}
$n$ \\
\multirow{T}{0}{} \\
0 \\
0 \\
0
\end{tabular} & 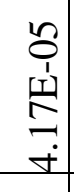 & $\begin{array}{l}n \\
8 \\
8 \\
8 \\
0 \\
0\end{array}$ & $\begin{array}{l}\stackrel{+}{~} \\
8 \\
8 \\
8 \\
0\end{array}$ & $\begin{array}{l}1 \\
\infty \\
0 \\
8 \\
0 \\
0\end{array}$ & 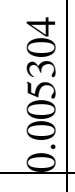 & 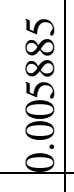 & 0 & 0 & 0 & 0 \\
\hline 9 & $\begin{array}{l}\overline{1} \\
\overline{8} \\
8 \\
\dot{0}\end{array}$ & 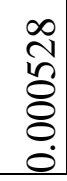 & 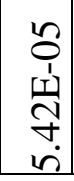 & \begin{tabular}{l}
$m$ \\
\multirow{J}{*}{} \\
8 \\
8 \\
$\dot{0}$
\end{tabular} & 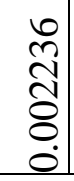 & $\begin{array}{l}n \\
\tilde{N} \\
n \\
0 \\
0\end{array}$ & $\begin{array}{c}\infty \\
0 \\
+ \\
8 \\
8 \\
0\end{array}$ & 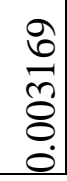 & 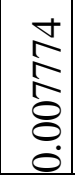 & $\begin{array}{l}0 \\
\text { ని } \\
\text { రి} \\
8 \\
0\end{array}$ & 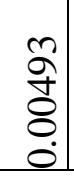 & $\begin{array}{l}\bar{F} \\
\infty \\
8 \\
0 \\
0\end{array}$ & $\begin{array}{l}n \\
m \\
\tilde{p} \\
\tilde{0} \\
\dot{0}\end{array}$ & 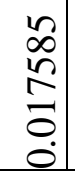 & 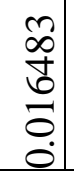 & 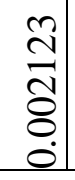 & 0 & 0 & 0 \\
\hline
\end{tabular}


11.6 Table - 6 Sector wise Competence Chart for manager

\begin{tabular}{|c|c|c|c|c|c|c|}
\hline $\begin{array}{l}\text { Indu } \\
\text { stry } \\
\text { code } \\
\end{array}$ & Industry & Occupation & SC1 & $\mathrm{SC} 2$ & SC3 & $\mathrm{SC} 4$ \\
\hline $\mathrm{A}$ & $\begin{array}{l}\text { Agriculture, } \\
\text { forestry and } \\
\text { fishing }\end{array}$ & $\begin{array}{l}\text { Crop } \\
\text { production } \\
\text { manager }\end{array}$ & $\begin{array}{l}\text { ensure } \\
\text { soil } \\
\text { fertility }\end{array}$ & $\begin{array}{l}\text { execute } \\
\text { disease } \\
\text { and pest } \\
\text { control } \\
\text { activities }\end{array}$ & $\begin{array}{l}\text { Manage } \\
\text { agricult } \\
\text { ural } \\
\text { staff }\end{array}$ & $\begin{array}{l}\text { Monitor } \\
\text { fields }\end{array}$ \\
\hline B & $\begin{array}{l}\text { Mining and } \\
\text { quarrying }\end{array}$ & $\begin{array}{l}\text { Mine } \\
\text { production } \\
\text { manager }\end{array}$ & $\begin{array}{l}\text { communi } \\
\text { cate on } \\
\text { minerals } \\
\text { issues }\end{array}$ & $\begin{array}{l}\text { Advise } \\
\text { on mine } \\
\text { equipme } \\
\text { nt }\end{array}$ & $\begin{array}{l}\text { Monitor } \\
\text { mine } \\
\text { costs }\end{array}$ & $\begin{array}{l}\text { Monitor } \\
\text { mine } \\
\text { production }\end{array}$ \\
\hline $\mathrm{C}$ & $\begin{array}{l}\text { Manufacturi } \\
\text { ng }\end{array}$ & $\begin{array}{l}\text { industrial } \\
\text { production } \\
\text { manager }\end{array}$ & $\begin{array}{l}\text { assess } \\
\text { supplier } \\
\text { risks }\end{array}$ & $\begin{array}{l}\text { adapt } \\
\text { producti } \\
\text { on levels }\end{array}$ & $\begin{array}{l}\text { analyse } \\
\text { producti } \\
\text { on } \\
\text { processe } \\
\text { s for } \\
\text { improve } \\
\text { ment }\end{array}$ & $\begin{array}{l}\text { analyse } \\
\text { supply } \\
\text { chain } \\
\text { strategies }\end{array}$ \\
\hline $\mathrm{D}$ & $\begin{array}{l}\text { Electricity, } \\
\text { gas, steam } \\
\text { and air- } \\
\text { conditioning } \\
\text { supply }\end{array}$ & $\begin{array}{l}\text { power plant } \\
\text { manager }\end{array}$ & $\begin{array}{l}\text { arrange } \\
\text { equipme } \\
\text { nt repairs }\end{array}$ & $\begin{array}{l}\text { design } \\
\text { strategie } \\
\text { s for } \\
\text { nuclear } \\
\text { emergen } \\
\text { cies }\end{array}$ & $\begin{array}{l}\text { develop } \\
\text { electricit } \\
\text { y } \\
\text { distribut } \\
\text { ion } \\
\text { schedule }\end{array}$ & $\begin{array}{l}\text { develop } \\
\text { strategies } \\
\text { for } \\
\text { electricity } \\
\text { contingenci } \\
\text { es }\end{array}$ \\
\hline $\mathrm{E}$ & $\begin{array}{l}\text { Water } \\
\text { supply, } \\
\text { sewerage, } \\
\text { waste } \\
\text { management } \\
\text { and } \\
\text { remediation }\end{array}$ & $\begin{array}{l}\text { water } \\
\text { treatment } \\
\text { plant } \\
\text { manager }\end{array}$ & $\begin{array}{l}\text { coordinat } \\
\text { e } \\
\text { environ } \\
\text { mental } \\
\text { efforts }\end{array}$ & $\begin{array}{l}\text { develop } \\
\text { water } \\
\text { purificat } \\
\text { ion } \\
\text { methods }\end{array}$ & $\begin{array}{l}\text { develop } \\
\text { water } \\
\text { supply } \\
\text { schedule }\end{array}$ & $\begin{array}{l}\text { ensure } \\
\text { compliance } \\
\text { with } \\
\text { environmen } \\
\text { tal } \\
\text { legislation }\end{array}$ \\
\hline $\mathrm{F}$ & Construction & $\begin{array}{l}\text { construction } \\
\text { quality } \\
\text { managers }\end{array}$ & $\begin{array}{l}\text { conduct } \\
\text { quality } \\
\text { control } \\
\text { analysis }\end{array}$ & $\begin{array}{l}\text { evaluate } \\
\text { budgets }\end{array}$ & $\begin{array}{l}\text { maintain } \\
\text { work } \\
\text { area } \\
\text { cleanlin } \\
\text { ess } \\
\end{array}$ & $\begin{array}{l}\text { make time- } \\
\text { critical } \\
\text { decisions }\end{array}$ \\
\hline $\mathrm{G}$ & $\begin{array}{l}\text { Wholesale } \\
\text { and retail } \\
\text { trade, repair } \\
\text { of motor } \\
\text { vehicles and } \\
\text { motorcycles }\end{array}$ & $\begin{array}{l}\text { sales } \\
\text { account } \\
\text { manager }\end{array}$ & $\begin{array}{l}\text { deliver a } \\
\text { sales } \\
\text { pitch }\end{array}$ & $\begin{array}{l}\text { perform } \\
\text { market } \\
\text { research }\end{array}$ & $\begin{array}{l}\text { pose } \\
\text { question } \\
\mathrm{s} \\
\text { referring } \\
\text { to } \\
\text { docume } \\
\text { nts }\end{array}$ & $\begin{array}{l}\text { use content } \\
\text { managemen } \\
\text { t system } \\
\text { software }\end{array}$ \\
\hline $\mathrm{H}$ & $\begin{array}{l}\text { Transportati } \\
\text { on and } \\
\text { storage }\end{array}$ & $\begin{array}{l}\text { warehouse } \\
\text { manager }\end{array}$ & $\begin{array}{l}\text { analyse } \\
\text { work- } \\
\text { related }\end{array}$ & $\begin{array}{l}\text { carry out } \\
\text { storage } \\
\text { risk }\end{array}$ & $\begin{array}{l}\text { ensure } \\
\text { special } \\
\text { require }\end{array}$ & $\begin{array}{l}\text { maintain } \\
\text { updated } \\
\text { professional }\end{array}$ \\
\hline
\end{tabular}




\begin{tabular}{|c|c|c|c|c|c|c|}
\hline $\begin{array}{l}\text { Indu } \\
\text { stry }\end{array}$ & Industry & Occupation & SC1 & $\mathrm{SC} 2$ & SC3 & $\mathrm{SC} 4$ \\
\hline & & & $\begin{array}{l}\text { written } \\
\text { reports }\end{array}$ & $\begin{array}{l}\text { manage } \\
\text { ment }\end{array}$ & $\begin{array}{l}\text { ments } \\
\text { for } \\
\text { goods in } \\
\text { storage }\end{array}$ & knowledge \\
\hline I & $\begin{array}{l}\text { Accommoda } \\
\text { tion and } \\
\text { food service } \\
\text { activities }\end{array}$ & $\begin{array}{l}\text { restaurant } \\
\text { manager }\end{array}$ & $\begin{array}{l}\text { keep up } \\
\text { with } \\
\text { trends in } \\
\text { eating } \\
\text { out }\end{array}$ & $\begin{array}{l}\text { inspect } \\
\text { table } \\
\text { settings }\end{array}$ & $\begin{array}{l}\text { enforce } \\
\text { alcohol } \\
\text { drinking } \\
\text { laws }\end{array}$ & $\begin{array}{l}\text { develop } \\
\text { working } \\
\text { procedures }\end{array}$ \\
\hline $\mathrm{J} 1$ & $\begin{array}{l}\text { Publishing, } \\
\text { audio-visual } \\
\text { and } \\
\text { broadcasting } \\
\text { activities, } \\
\text { telecommuni } \\
\text { cations and } \\
\text { other } \\
\text { information } \\
\text { services }\end{array}$ & $\begin{array}{l}\text { telecommuni } \\
\text { cations } \\
\text { manager }\end{array}$ & $\begin{array}{l}\text { apply } \\
\text { procure } \\
\text { ment }\end{array}$ & $\begin{array}{l}\text { calibrate } \\
\text { electroni } \\
\text { c } \\
\text { instrume } \\
\text { nts }\end{array}$ & $\begin{array}{l}\text { impleme } \\
\text { nt } \\
\text { corporat } \\
\text { e } \\
\text { governa } \\
\text { nce }\end{array}$ & $\begin{array}{l}\text { telecommun } \\
\text { ication } \\
\text { trunking }\end{array}$ \\
\hline K & $\begin{array}{l}\text { Financial } \\
\text { and } \\
\text { insurance } \\
\text { activities }\end{array}$ & $\begin{array}{l}\text { insurance } \\
\text { product } \\
\text { manager }\end{array}$ & $\begin{array}{l}\text { create } \\
\text { cooperati } \\
\text { on } \\
\text { modalitie } \\
\text { s }\end{array}$ & $\begin{array}{l}\text { deliver a } \\
\text { sales } \\
\text { pitch }\end{array}$ & $\begin{array}{l}\text { develop } \\
\text { investm } \\
\text { ent } \\
\text { portfolio }\end{array}$ & $\begin{array}{l}\text { ensure } \\
\text { cross- } \\
\text { department } \\
\text { cooperation }\end{array}$ \\
\hline $\mathrm{L}$ & $\begin{array}{l}\text { Real estate } \\
\text { activities }\end{array}$ & $\begin{array}{l}\text { real estate } \\
\text { manager }\end{array}$ & $\begin{array}{l}\text { provide } \\
\text { informati } \\
\text { on on } \\
\text { propertie } \\
\text { S }\end{array}$ & $\begin{array}{l}\text { negotiat } \\
\text { e with } \\
\text { property } \\
\text { owners }\end{array}$ & $\begin{array}{l}\text { inform } \\
\text { on } \\
\text { renting } \\
\text { agreeme } \\
\text { nts }\end{array}$ & $\begin{array}{l}\text { advise on } \\
\text { property } \\
\text { value }\end{array}$ \\
\hline $\mathrm{M}$ & $\begin{array}{l}\text { Legal, } \\
\text { accounting, } \\
\text { management } \\
\text { architecture, } \\
\text { engineering, } \\
\text { technical } \\
\text { testing and } \\
\text { analysis } \\
\text { activities, } \\
\text { scientific } \\
\text { research and } \\
\text { development } \\
\text {, other } \\
\text { professional, } \\
\text { scientific } \\
\text { and }\end{array}$ & $\begin{array}{l}\text { ICT research } \\
\text { manager }\end{array}$ & $\begin{array}{l}\text { create } \\
\text { solutions } \\
\text { to } \\
\text { problems }\end{array}$ & $\begin{array}{l}\text { coordina } \\
\text { te } \\
\text { technolo } \\
\text { gical } \\
\text { activities }\end{array}$ & $\begin{array}{l}\text { conduct } \\
\text { research } \\
\text { intervie } \\
\text { w }\end{array}$ & $\begin{array}{l}\text { apply } \\
\text { reverse } \\
\text { engineering }\end{array}$ \\
\hline
\end{tabular}




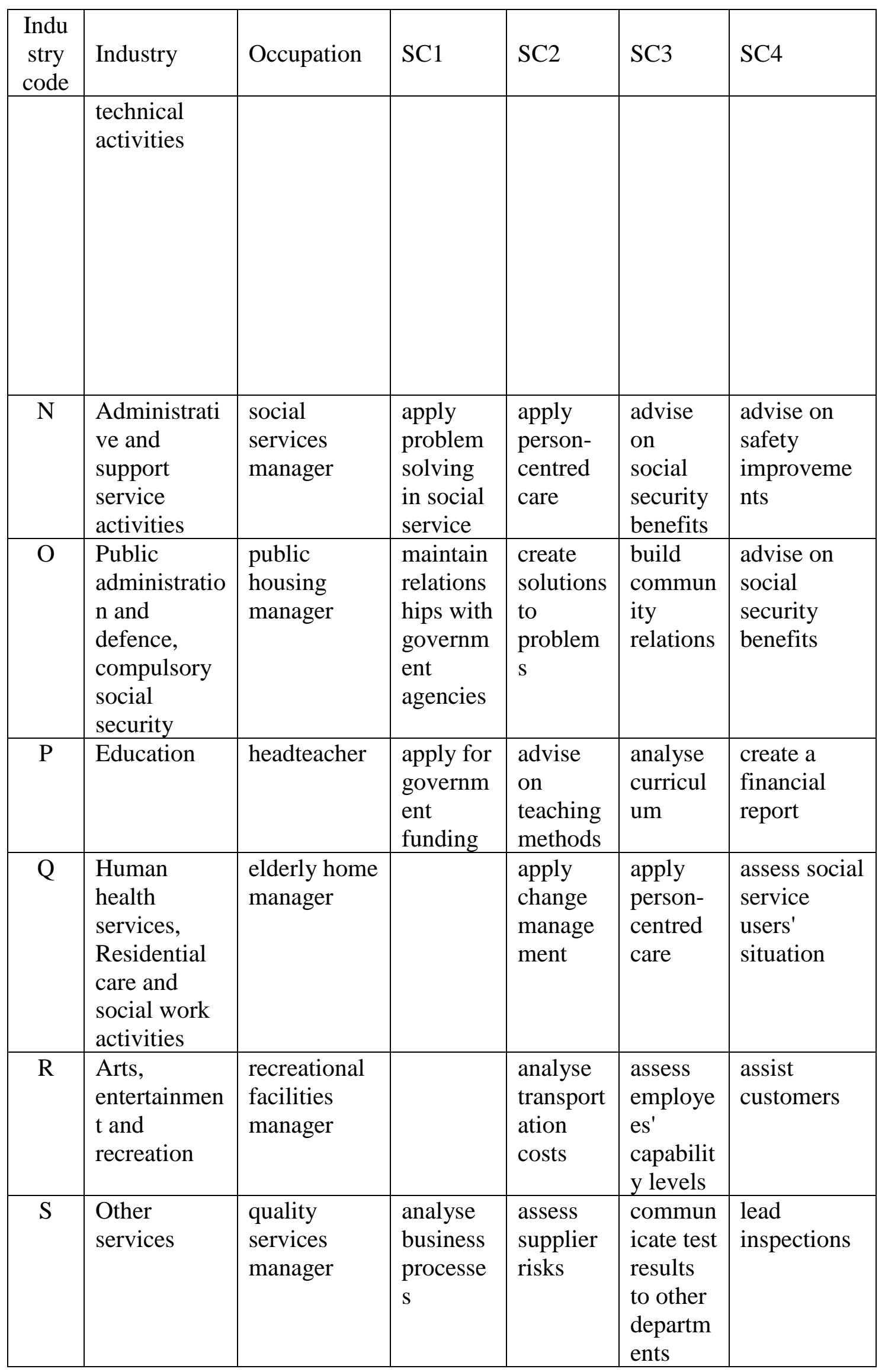




\begin{tabular}{|c|c|c|c|c|c|c|c|c|}
\hline $\begin{array}{l}\text { Indu } \\
\text { stry } \\
\text { code }\end{array}$ & SC5 & SC6 & SC7 & SC8 & SC9 & SC10 & SC11 & $\begin{array}{l}\text { SC1 } \\
2\end{array}$ \\
\hline A & $\begin{array}{l}\text { Operate } \\
\text { agricult } \\
\text { ural } \\
\text { machin } \\
\text { ery }\end{array}$ & $\begin{array}{l}\text { Store } \\
\text { crops }\end{array}$ & $\begin{array}{l}\text { Supervi } \\
\text { se crop } \\
\text { producti } \\
\text { on }\end{array}$ & $\begin{array}{l}\text { Supervi } \\
\text { se } \\
\text { hygiene } \\
\text { procedu } \\
\text { res in } \\
\text { agricult } \\
\text { ural } \\
\text { settings }\end{array}$ & $\begin{array}{l}\text { store } \\
\text { product } \\
\mathrm{s}\end{array}$ & $\begin{array}{l}\text { manage } \\
\text { producti } \\
\text { on } \\
\text { enterpri } \\
\text { se }\end{array}$ & $\begin{array}{l}\text { maintai } \\
\mathrm{n} \\
\text { technic } \\
\text { al } \\
\text { equipm } \\
\text { ent }\end{array}$ & $\begin{array}{l}\text { main } \\
\text { tain } \\
\text { stora } \\
\text { ge } \\
\text { facil } \\
\text { ities }\end{array}$ \\
\hline B & $\begin{array}{l}\text { report } \\
\text { on } \\
\text { producti } \\
\text { on } \\
\text { results }\end{array}$ & $\begin{array}{l}\text { advise } \\
\text { on } \\
\text { mine } \\
\text { equipm } \\
\text { ent }\end{array}$ & & & & & & \\
\hline $\mathrm{C}$ & $\begin{array}{l}\text { check } \\
\text { quality } \\
\text { of } \\
\text { product } \\
\text { s on the } \\
\text { producti } \\
\text { on line }\end{array}$ & $\begin{array}{l}\text { check } \\
\text { quality } \\
\text { of raw } \\
\text { materia } \\
\text { ls }\end{array}$ & $\begin{array}{l}\text { adjust } \\
\text { producti } \\
\text { on } \\
\text { schedul } \\
\text { e }\end{array}$ & $\begin{array}{l}\text { assess } \\
\text { impact } \\
\text { of } \\
\text { industri } \\
\text { al } \\
\text { activitie } \\
\text { s }\end{array}$ & & & & \\
\hline $\mathrm{D}$ & $\begin{array}{l}\text { ensure } \\
\text { complia } \\
\text { nce } \\
\text { with } \\
\text { electrici }\end{array}$ & $\begin{array}{l}\text { ensure } \\
\text { compli } \\
\text { ance } \\
\text { with } \\
\text { radiatio }\end{array}$ & $\begin{array}{l}\text { ensure } \\
\text { safety in } \\
\text { electrica } \\
\text { 1 power } \\
\text { operatio }\end{array}$ & $\begin{array}{l}\text { analyse } \\
\text { energy } \\
\text { market } \\
\text { trends }\end{array}$ & $\begin{array}{l}\text { coordin } \\
\text { ate } \\
\text { electrici } \\
\text { ty } \\
\text { generati }\end{array}$ & $\begin{array}{l}\text { create } \\
\text { manufa } \\
\text { cturing } \\
\text { guidelin } \\
\text { es }\end{array}$ & & \\
\hline
\end{tabular}




\begin{tabular}{|c|c|c|c|c|c|c|c|c|}
\hline $\begin{array}{l}\text { Indu } \\
\text { stry } \\
\text { code }\end{array}$ & SC5 & SC6 & SC7 & SC8 & SC9 & SC10 & SC11 & $\begin{array}{l}\mathrm{SC} 1 \\
2\end{array}$ \\
\hline & $\begin{array}{l}\text { ty } \\
\text { distribut } \\
\text { ion } \\
\text { schedul } \\
\text { e }\end{array}$ & $\begin{array}{l}\mathrm{n} \\
\text { protecti } \\
\text { on } \\
\text { regulati } \\
\text { ons }\end{array}$ & $\mathrm{ns}$ & & on & & & \\
\hline $\mathrm{E}$ & $\begin{array}{l}\text { ensure } \\
\text { regulato } \\
\text { ry } \\
\text { complia } \\
\text { nce in } \\
\text { pipeline } \\
\text { infrastr } \\
\text { uctures }\end{array}$ & $\begin{array}{l}\text { inform } \\
\text { on } \\
\text { water } \\
\text { supply }\end{array}$ & $\begin{array}{l}\text { liaise } \\
\text { with } \\
\text { local } \\
\text { authoriti } \\
\text { es }\end{array}$ & $\begin{array}{l}\text { create } \\
\text { manufa } \\
\text { cturing } \\
\text { guidelin } \\
\text { es }\end{array}$ & $\begin{array}{l}\text { define } \\
\text { manufa } \\
\text { cturing } \\
\text { quality } \\
\text { criteria }\end{array}$ & $\begin{array}{l}\text { develop } \\
\text { manufa } \\
\text { cturing } \\
\text { policies }\end{array}$ & & \\
\hline $\mathrm{F}$ & $\begin{array}{l}\text { monitor } \\
\text { constru } \\
\text { ction } \\
\text { site }\end{array}$ & $\begin{array}{l}\text { organis } \\
\text { e } \\
\text { quality } \\
\text { circle }\end{array}$ & $\begin{array}{l}\text { review } \\
\text { construc } \\
\text { tion } \\
\text { plans } \\
\text { authoris } \\
\text { ations }\end{array}$ & $\begin{array}{l}\text { adjust } \\
\text { enginee } \\
\text { ring } \\
\text { designs }\end{array}$ & $\begin{array}{l}\text { advise } \\
\text { on } \\
\text { constru } \\
\text { ction } \\
\text { material } \\
\text { s }\end{array}$ & $\begin{array}{l}\text { check } \\
\text { compati } \\
\text { bility of } \\
\text { material } \\
\text { s }\end{array}$ & $\begin{array}{l}\text { commu } \\
\text { nicate } \\
\text { with } \\
\text { externa } \\
1 \\
\text { laborat } \\
\text { ories }\end{array}$ & \\
\hline G & $\begin{array}{l}\text { use } \\
\text { custome } \\
\mathrm{r} \\
\text { relation } \\
\text { ship } \\
\text { manage } \\
\text { ment }\end{array}$ & & & & & & & \\
\hline
\end{tabular}




\begin{tabular}{|c|c|c|c|c|c|c|c|c|}
\hline $\begin{array}{l}\text { Indu } \\
\text { stry } \\
\text { code }\end{array}$ & SC5 & SC6 & SC7 & SC8 & SC9 & SC10 & SC11 & $\begin{array}{l}\text { SC1 } \\
2\end{array}$ \\
\hline & $\begin{array}{l}\text { softwar } \\
\text { e }\end{array}$ & & & & & & & \\
\hline $\mathrm{H}$ & $\begin{array}{l}\text { perform } \\
\text { services } \\
\text { in a } \\
\text { flexible } \\
\text { manner }\end{array}$ & & & & & & & \\
\hline I & $\begin{array}{l}\text { create } \\
\text { event- } \\
\text { specific } \\
\text { menus }\end{array}$ & $\begin{array}{l}\text { create } \\
\text { decorat } \\
\text { ive } \\
\text { food } \\
\text { display } \\
\text { s }\end{array}$ & $\begin{array}{l}\text { compile } \\
\text { wine } \\
\text { lists }\end{array}$ & $\begin{array}{l}\text { apply } \\
\text { foreign } \\
\text { languag } \\
\text { es in } \\
\text { hospital } \\
\text { ity }\end{array}$ & $\begin{array}{l}\text { comply } \\
\text { with } \\
\text { food } \\
\text { safety } \\
\text { and } \\
\text { hygiene }\end{array}$ & & & \\
\hline $\mathrm{J} 1$ & $\begin{array}{l}\text { upgrade } \\
\text { firmwar } \\
\text { e }\end{array}$ & $\begin{array}{l}\text { provide } \\
\text { cost } \\
\text { benefit } \\
\text { analysi } \\
\text { s } \\
\text { reports }\end{array}$ & $\begin{array}{l}\text { operate } \\
\text { private } \\
\text { branch } \\
\text { exchang } \\
\text { e }\end{array}$ & $\begin{array}{l}\text { comply } \\
\text { with } \\
\text { legal } \\
\text { regulati } \\
\text { ons }\end{array}$ & $\begin{array}{l}\text { coordin } \\
\text { ate } \\
\text { technol } \\
\text { ogical } \\
\text { activitie } \\
\text { s }\end{array}$ & $\begin{array}{l}\text { execute } \\
\text { ICT } \\
\text { audits }\end{array}$ & $\begin{array}{l}\text { implem } \\
\text { ent ICT } \\
\text { risk } \\
\text { manage } \\
\text { ment }\end{array}$ & \\
\hline K & $\begin{array}{l}\text { obtain } \\
\text { financia } \\
1 \\
\text { informa } \\
\text { tion }\end{array}$ & $\begin{array}{l}\text { perfor } \\
\mathrm{m} \\
\text { market } \\
\text { researc } \\
\mathrm{h}\end{array}$ & $\begin{array}{l}\text { advise } \\
\text { on } \\
\text { financia } \\
1 \\
\text { matters }\end{array}$ & $\begin{array}{l}\text { analyse } \\
\text { financia } \\
1 \\
\text { perform } \\
\text { ance of } \\
\text { a } \\
\text { compan }\end{array}$ & $\begin{array}{l}\text { analyse } \\
\text { financia } \\
1 \text { risk }\end{array}$ & $\begin{array}{l}\text { analyse } \\
\text { market } \\
\text { financia } \\
1 \text { trends }\end{array}$ & & \\
\hline
\end{tabular}




\begin{tabular}{|c|c|c|c|c|c|c|c|c|}
\hline $\begin{array}{l}\text { Indu } \\
\text { stry } \\
\text { code }\end{array}$ & SC5 & SC6 & SC7 & SC8 & SC9 & SC10 & SC11 & $\begin{array}{l}\text { SC1 } \\
2\end{array}$ \\
\hline & & & & $\mathrm{y}$ & & & & \\
\hline $\mathrm{L}$ & $\begin{array}{l}\text { attend } \\
\text { trade } \\
\text { fairs }\end{array}$ & $\begin{array}{l}\text { develo } \\
\mathrm{p} \\
\text { profess } \\
\text { ional } \\
\text { networ } \\
\mathrm{k}\end{array}$ & $\begin{array}{l}\text { examine } \\
\text { the } \\
\text { conditio } \\
\text { ns of } \\
\text { building } \\
\text { s }\end{array}$ & $\begin{array}{l}\text { advise } \\
\text { on } \\
\text { financia } \\
1 \\
\text { matters }\end{array}$ & $\begin{array}{l}\text { analyse } \\
\text { financia } \\
1 \\
\text { perform } \\
\text { ance of } \\
\text { a } \\
\text { compan } \\
\text { y }\end{array}$ & $\begin{array}{l}\text { analyse } \\
\text { market } \\
\text { financia } \\
1 \text { trends }\end{array}$ & $\begin{array}{l}\text { analyse } \\
\text { insuran } \\
\text { ce risk }\end{array}$ & \\
\hline $\mathrm{M}$ & $\begin{array}{l}\text { execute } \\
\text { ICT } \\
\text { user } \\
\text { research } \\
\text { activitie } \\
\text { s }\end{array}$ & $\begin{array}{l}\text { execute } \\
\text { analyti } \\
\text { cal } \\
\text { mathe } \\
\text { matical } \\
\text { calculat } \\
\text { ions }\end{array}$ & $\begin{array}{l}\text { apply } \\
\text { system } \\
\text { organisa } \\
\text { tional } \\
\text { policies }\end{array}$ & $\begin{array}{l}\text { conduct } \\
\text { literatur } \\
\text { e } \\
\text { research }\end{array}$ & $\begin{array}{l}\text { analyse } \\
\text { market } \\
\text { financia } \\
1 \text { trends }\end{array}$ & $\begin{array}{l}\text { perform } \\
\text { data } \\
\text { mining }\end{array}$ & & \\
\hline $\mathrm{N}$ & $\begin{array}{l}\text { apply } \\
\text { conflict } \\
\text { manage } \\
\text { ment }\end{array}$ & $\begin{array}{l}\text { apply } \\
\text { foreign } \\
\text { langua } \\
\text { ges in } \\
\text { social } \\
\text { service } \\
\text { s }\end{array}$ & $\begin{array}{l}\text { apply } \\
\text { organisa } \\
\text { tional } \\
\text { techniq } \\
\text { ues }\end{array}$ & & & & & \\
\hline $\mathrm{O}$ & $\begin{array}{l}\text { develop } \\
\text { social } \\
\text { security }\end{array}$ & $\begin{array}{l}\text { ensure } \\
\text { cross- } \\
\text { depart }\end{array}$ & $\begin{array}{l}\text { investig } \\
\text { ate } \\
\text { social }\end{array}$ & & & & & \\
\hline
\end{tabular}




\begin{tabular}{|c|c|c|c|c|c|c|c|c|}
\hline $\begin{array}{l}\text { Indu } \\
\text { stry } \\
\text { code }\end{array}$ & SC5 & SC6 & SC7 & SC8 & SC9 & SC10 & SC11 & $\begin{array}{l}\text { SC1 } \\
2\end{array}$ \\
\hline & $\begin{array}{l}\text { progra } \\
\text { mmes }\end{array}$ & $\begin{array}{l}\text { ment } \\
\text { cooper } \\
\text { ation }\end{array}$ & $\begin{array}{l}\text { security } \\
\text { applicat } \\
\text { ions }\end{array}$ & & & & & \\
\hline $\mathrm{P}$ & $\begin{array}{l}\text { develop } \\
\text { curricul } \\
\text { um }\end{array}$ & $\begin{array}{l}\text { evaluat } \\
\text { e } \\
\text { budgets }\end{array}$ & $\begin{array}{l}\text { evaluate } \\
\text { educatio } \\
\mathrm{n} \\
\text { program } \\
\text { mes }\end{array}$ & $\begin{array}{l}\text { identify } \\
\text { educati } \\
\text { on } \\
\text { needs }\end{array}$ & $\begin{array}{l}\text { commu } \\
\text { nicate } \\
\text { with } \\
\text { youth }\end{array}$ & $\begin{array}{l}\text { coopera } \\
\text { te with } \\
\text { educati } \\
\text { on } \\
\text { professi } \\
\text { onals }\end{array}$ & $\begin{array}{l}\text { handle } \\
\text { financi } \\
\text { al } \\
\text { transact } \\
\text { ions }\end{array}$ & \\
\hline $\mathrm{Q}$ & $\begin{array}{l}\text { assist } \\
\text { social } \\
\text { service } \\
\text { users } \\
\text { with } \\
\text { physical } \\
\text { disabilit } \\
\text { ies }\end{array}$ & $\begin{array}{l}\text { commu } \\
\text { nicate } \\
\text { with } \\
\text { others } \\
\text { who } \\
\text { are } \\
\text { signific } \\
\text { ant to } \\
\text { service } \\
\text { users }\end{array}$ & $\begin{array}{l}\text { contribu } \\
\text { te to } \\
\text { protecti } \\
\text { ng } \\
\text { individu } \\
\text { als from } \\
\text { harm }\end{array}$ & $\begin{array}{l}\text { evaluate } \\
\text { older } \\
\text { adults' } \\
\text { ability } \\
\text { to take } \\
\text { care of } \\
\text { themsel } \\
\text { ves }\end{array}$ & $\begin{array}{l}\text { advocat } \\
\text { e for } \\
\text { social } \\
\text { service } \\
\text { users }\end{array}$ & & & \\
\hline $\mathrm{R}$ & $\begin{array}{l}\text { check } \\
\text { in } \\
\text { guests }\end{array}$ & $\begin{array}{l}\text { coordin } \\
\text { ate } \\
\text { adverti } \\
\text { sing } \\
\text { campai } \\
\text { gns }\end{array}$ & $\begin{array}{l}\text { coordin } \\
\text { ate } \\
\text { events }\end{array}$ & $\begin{array}{l}\text { liaise } \\
\text { with } \\
\text { local } \\
\text { authorit } \\
\text { ies }\end{array}$ & $\begin{array}{l}\text { develop } \\
\text { recreati } \\
\text { on } \\
\text { progra } \\
\text { mmes }\end{array}$ & $\begin{array}{l}\text { manage } \\
\text { logistics }\end{array}$ & & \\
\hline
\end{tabular}




\begin{tabular}{|c|c|c|c|c|c|c|c|c|}
\hline $\begin{array}{l}\text { Indu } \\
\text { stry } \\
\text { code }\end{array}$ & SC5 & SC6 & SC7 & SC8 & SC9 & SC10 & SC11 & $\begin{array}{l}\text { SC1 } \\
2\end{array}$ \\
\hline$S$ & $\begin{array}{l}\text { perform } \\
\text { pre- } \\
\text { assembl } \\
\text { y } \\
\text { quality } \\
\text { checks }\end{array}$ & $\begin{array}{l}\text { perfor } \\
\mathrm{m} \\
\text { project } \\
\text { manage } \\
\text { ment }\end{array}$ & $\begin{array}{l}\text { provide } \\
\text { technica } \\
1 \\
\text { docume } \\
\text { ntation }\end{array}$ & $\begin{array}{l}\text { set } \\
\text { quality } \\
\text { assuran } \\
\text { ce } \\
\text { objectiv } \\
\text { es }\end{array}$ & $\begin{array}{l}\text { analyse } \\
\text { test data }\end{array}$ & $\begin{array}{l}\text { create } \\
\text { solution } \\
\mathrm{s} \text { to } \\
\text { problem } \\
\mathrm{s}\end{array}$ & & \\
\hline
\end{tabular}

\subsection{General Competence Chart for manager}

\begin{tabular}{|c|c|c|c|c|c|c|c|c|c|}
\hline $\begin{array}{l}\text { Indu } \\
\text { stry } \\
\text { code }\end{array}$ & $\begin{array}{l}\text { Industr } \\
\mathrm{y}\end{array}$ & Occupation & $\mathrm{GC} 1$ & GC2 & GC3 & GC 4 & GC5 & GC6 & GC 7 \\
\hline $\mathrm{A}$ & $\begin{array}{l}\text { Agricul } \\
\text { ture, } \\
\text { forestry } \\
\text { and } \\
\text { fishing }\end{array}$ & $\begin{array}{l}\text { crop } \\
\text { production } \\
\text { manager }\end{array}$ & & & & & & & \\
\hline B & $\begin{array}{l}\text { Mining } \\
\text { and } \\
\text { quarryi } \\
\text { ng }\end{array}$ & $\begin{array}{l}\text { Mine } \\
\text { production } \\
\text { manager }\end{array}$ & $\begin{array}{l}\text { manag } \\
\text { e staff }\end{array}$ & $\begin{array}{l}\text { addres } \\
\text { s } \\
\text { proble } \\
\text { ms } \\
\text { critical } \\
\text { ly }\end{array}$ & $\begin{array}{l}\text { deal } \\
\text { with } \\
\text { pressur } \\
\text { e from } \\
\text { unexpe } \\
\text { cted } \\
\text { circum } \\
\text { stances }\end{array}$ & $\begin{array}{l}\text { supervi } \\
\text { se staff }\end{array}$ & $\begin{array}{l}\text { plan } \\
\text { mediu } \\
\mathrm{m} \text { to } \\
\text { long } \\
\text { term } \\
\text { objecti } \\
\text { ves }\end{array}$ & $\begin{array}{l}\text { present } \\
\text { reports }\end{array}$ & \\
\hline $\mathrm{C}$ & $\begin{array}{l}\text { Manufa } \\
\text { cturing }\end{array}$ & $\begin{array}{l}\text { industrial } \\
\text { production } \\
\text { manager }\end{array}$ & $\begin{array}{l}\text { manag } \\
\text { e } \\
\text { resourc } \\
\text { es }\end{array}$ & $\begin{array}{l}\text { adhere } \\
\text { to } \\
\text { organis } \\
\text { ational } \\
\text { guideli } \\
\text { nes }\end{array}$ & $\begin{array}{l}\text { analys } \\
\text { e goal } \\
\text { progre } \\
\text { ss }\end{array}$ & & & & \\
\hline $\mathrm{D}$ & $\begin{array}{l}\text { Electric } \\
\text { ity, gas, } \\
\text { steam } \\
\text { and air- } \\
\text { conditio } \\
\text { ning } \\
\text { supply }\end{array}$ & $\begin{array}{l}\text { power } \\
\text { plant } \\
\text { manager }\end{array}$ & $\begin{array}{l}\text { adhere } \\
\text { to } \\
\text { organis } \\
\text { ational } \\
\text { guideli } \\
\text { nes }\end{array}$ & $\begin{array}{l}\text { hire } \\
\text { new } \\
\text { person } \\
\text { nel }\end{array}$ & & & & & \\
\hline E & $\begin{array}{l}\text { Water } \\
\text { supply, } \\
\text { sewerag } \\
\text { e, waste } \\
\text { manage } \\
\text { ment }\end{array}$ & $\begin{array}{l}\text { water } \\
\text { treatment } \\
\text { plant } \\
\text { manager }\end{array}$ & $\begin{array}{l}\text { adhere } \\
\text { to } \\
\text { organis } \\
\text { ational } \\
\text { guideli } \\
\text { nes }\end{array}$ & $\begin{array}{l}\text { hire } \\
\text { new } \\
\text { person } \\
\text { nel }\end{array}$ & & & & & \\
\hline
\end{tabular}




\begin{tabular}{|c|c|c|c|c|c|c|c|c|c|}
\hline $\begin{array}{l}\text { Indu } \\
\text { stry } \\
\text { code }\end{array}$ & $\begin{array}{l}\text { Industr } \\
\mathrm{y}\end{array}$ & Occupation & GC1 & GC2 & GC3 & GC 4 & GC5 & GC6 & GC 7 \\
\hline & $\begin{array}{l}\text { and } \\
\text { remedia } \\
\text { tion }\end{array}$ & & & & & & & & \\
\hline $\mathrm{F}$ & $\begin{array}{l}\text { Constru } \\
\text { ction }\end{array}$ & $\begin{array}{l}\text { constructio } \\
\mathrm{n} \quad \text { quality } \\
\text { managers }\end{array}$ & $\begin{array}{l}\text { evaluat } \\
\text { e } \\
\text { emplo } \\
\text { yees } \\
\text { work }\end{array}$ & & & & & & \\
\hline $\mathrm{G}$ & $\begin{array}{l}\text { Wholes } \\
\text { ale and } \\
\text { retail } \\
\text { trade, } \\
\text { repair } \\
\text { of } \\
\text { motor } \\
\text { vehicles } \\
\text { and } \\
\text { motorc } \\
\text { ycles }\end{array}$ & $\begin{array}{l}\text { sales } \\
\text { account } \\
\text { manager }\end{array}$ & $\begin{array}{l}\text { apply } \\
\text { compa } \\
\text { ny } \\
\text { policie } \\
\text { s }\end{array}$ & $\begin{array}{l}\text { build } \\
\text { busine } \\
\text { ss } \\
\text { relatio } \\
\text { nships }\end{array}$ & $\begin{array}{l}\text { ensure } \\
\text { custom } \\
\text { er } \\
\text { focus }\end{array}$ & $\begin{array}{l}\text { forecas } \\
\mathrm{t} \\
\text { accoun } \\
\mathrm{t} \\
\text { metrics }\end{array}$ & $\begin{array}{l}\text { adapt } \\
\text { to } \\
\text { changi } \\
\text { ng } \\
\text { situatio } \\
\text { ns }\end{array}$ & $\begin{array}{l}\text { speak } \\
\text { differe } \\
\text { nt } \\
\text { langua } \\
\text { ges }\end{array}$ & $\begin{array}{l}\text { use } \\
\text { comm } \\
\text { unicati } \\
\text { on } \\
\text { techniq } \\
\text { ues }\end{array}$ \\
\hline $\mathrm{H}$ & $\begin{array}{l}\text { Transpo } \\
\text { rtation } \\
\text { and } \\
\text { storage }\end{array}$ & $\begin{array}{l}\text { warehouse } \\
\text { manager }\end{array}$ & $\begin{array}{l}\text { apply } \\
\text { safety } \\
\text { manag } \\
\text { ement }\end{array}$ & $\begin{array}{l}\text { coach } \\
\text { emplo } \\
\text { yees }\end{array}$ & $\begin{array}{l}\text { build } \\
\text { busine } \\
\text { ss } \\
\text { relatio } \\
\text { nships }\end{array}$ & $\begin{array}{l}\text { compr } \\
\text { ehend } \\
\text { financi } \\
\text { al } \\
\text { busine } \\
\text { ss } \\
\text { termin } \\
\text { ology }\end{array}$ & $\begin{array}{l}\text { act } \\
\text { reliabl } \\
\mathrm{y}\end{array}$ & $\begin{array}{l}\text { have } \\
\text { compu } \\
\text { ter } \\
\text { literac } \\
\text { y }\end{array}$ & $\begin{array}{l}\text { manag } \\
\mathrm{e} \\
\text { budget } \\
\mathrm{s}\end{array}$ \\
\hline I & $\begin{array}{l}\text { Accom } \\
\text { modatio } \\
\mathrm{n} \text { and } \\
\text { food } \\
\text { service } \\
\text { activitie } \\
\text { s }\end{array}$ & $\begin{array}{l}\text { restaurant } \\
\text { manager }\end{array}$ & $\begin{array}{l}\text { arrang } \\
\text { e } \\
\text { special } \\
\text { events }\end{array}$ & $\begin{array}{l}\text { control } \\
\text { of } \\
\text { expens } \\
\text { es }\end{array}$ & $\begin{array}{l}\text { devise } \\
\text { special } \\
\text { promot } \\
\text { ions }\end{array}$ & & & & \\
\hline J1 & $\begin{array}{l}\text { Publishi } \\
\text { ng, } \\
\text { audio- } \\
\text { visual } \\
\text { and } \\
\text { broadca } \\
\text { sting } \\
\text { activitie } \\
\text { s, } \\
\text { telecom } \\
\text { municat } \\
\text { ions } \\
\text { and } \\
\text { other } \\
\text { informa } \\
\text { tion } \\
\text { services }\end{array}$ & $\begin{array}{l}\text { telecommu } \\
\text { nications } \\
\text { manager }\end{array}$ & $\begin{array}{l}\text { train } \\
\text { emplo } \\
\text { yees }\end{array}$ & & & & & & \\
\hline $\bar{K}$ & $\begin{array}{l}\text { Financi } \\
\text { al and } \\
\text { insuran } \\
\text { ce } \\
\text { activitie }\end{array}$ & $\begin{array}{l}\text { insurance } \\
\text { product } \\
\text { manager }\end{array}$ & & & & & $\begin{array}{l}\text { manag } \\
\text { e staff }\end{array}$ & $\begin{array}{l}\text { recruit } \\
\text { emplo } \\
\text { yees }\end{array}$ & \\
\hline
\end{tabular}




\begin{tabular}{|c|c|c|c|c|c|c|c|c|c|}
\hline $\begin{array}{l}\text { Indu } \\
\text { stry } \\
\text { code }\end{array}$ & $\begin{array}{l}\text { Industr } \\
\mathrm{y}\end{array}$ & Occupation & GC1 & GC2 & GC3 & GC 4 & GC5 & GC6 & GC 7 \\
\hline & $\mathrm{s}$ & & & & & & & & \\
\hline $\mathrm{L}$ & $\begin{array}{l}\text { Real } \\
\text { estate } \\
\text { activitie } \\
\text { s }\end{array}$ & $\begin{array}{l}\text { real estate } \\
\text { manager }\end{array}$ & & & & & $\begin{array}{l}\text { manag } \\
\mathrm{e} \\
\text { budget } \\
\mathrm{s}\end{array}$ & & \\
\hline M & $\begin{array}{l}\text { Legal, } \\
\text { account } \\
\text { ing, } \\
\text { manage } \\
\text { ment, } \\
\text { architec } \\
\text { ture, } \\
\text { enginee } \\
\text { ring, } \\
\text { technic } \\
\text { al } \\
\text { testing } \\
\text { and } \\
\text { analysis } \\
\text { activitie } \\
\text { s, } \\
\text { scientifi } \\
\text { c } \\
\text { researc } \\
\text { h and } \\
\text { develop } \\
\text { ment, } \\
\text { other } \\
\text { professi } \\
\text { onal, } \\
\text { scientifi } \\
\text { c and } \\
\text { technic } \\
\text { al } \\
\text { activitie } \\
\text { s }\end{array}$ & $\begin{array}{l}\text { ICT } \\
\text { research } \\
\text { manager }\end{array}$ & $\begin{array}{l}\text { apply } \\
\text { statisti } \\
\text { cal } \\
\text { analysi } \\
\text { s } \\
\text { techniq } \\
\text { ues }\end{array}$ & & & & $\begin{array}{l}\text { build } \\
\text { busine } \\
\text { ss } \\
\text { relatio } \\
\text { nships }\end{array}$ & & \\
\hline $\mathrm{N}$ & $\begin{array}{l}\text { Admini } \\
\text { strative } \\
\text { and } \\
\text { support } \\
\text { service } \\
\text { activitie } \\
\text { s }\end{array}$ & $\begin{array}{l}\text { social } \\
\text { services } \\
\text { manager }\end{array}$ & $\begin{array}{l}\text { accept } \\
\text { own } \\
\text { accoun } \\
\text { tability }\end{array}$ & $\begin{array}{l}\text { addres } \\
\mathrm{s} \\
\text { proble } \\
\mathrm{ms} \\
\text { critical } \\
\text { ly }\end{array}$ & $\begin{array}{l}\text { adhere } \\
\text { to } \\
\text { organis } \\
\text { ational } \\
\text { guideli } \\
\text { nes }\end{array}$ & $\begin{array}{l}\text { advoca } \\
\text { te for } \\
\text { others }\end{array}$ & $\begin{array}{l}\text { analys } \\
\text { e goal } \\
\text { progre } \\
\text { ss }\end{array}$ & & \\
\hline $\mathrm{O}$ & $\begin{array}{l}\text { Public } \\
\text { adminis } \\
\text { tration } \\
\text { and } \\
\text { defence } \\
\text { compul } \\
\text { sory } \\
\text { social } \\
\text { security }\end{array}$ & $\begin{array}{l}\text { public } \\
\text { housing } \\
\text { manager }\end{array}$ & $\begin{array}{l}\text { accept } \\
\text { own } \\
\text { accoun } \\
\text { tability }\end{array}$ & $\begin{array}{l}\text { addres } \\
\text { s } \\
\text { proble } \\
\text { ms } \\
\text { critical } \\
\text { ly }\end{array}$ & $\begin{array}{l}\text { adhere } \\
\text { to } \\
\text { organis } \\
\text { ational } \\
\text { guideli } \\
\text { nes }\end{array}$ & $\begin{array}{l}\text { advoca } \\
\text { te for } \\
\text { others }\end{array}$ & $\begin{array}{l}\text { delegat } \\
\text { e } \\
\text { activiti } \\
\text { es }\end{array}$ & & \\
\hline $\mathrm{P}$ & $\begin{array}{l}\text { Educati } \\
\text { on }\end{array}$ & $\begin{array}{l}\text { headteache } \\
\text { r }\end{array}$ & $\begin{array}{l}\text { develo } \\
\text { p }\end{array}$ & & & & & & \\
\hline
\end{tabular}




\begin{tabular}{|c|c|c|c|c|c|c|c|c|c|}
\hline $\begin{array}{l}\text { Indu } \\
\text { stry } \\
\text { code }\end{array}$ & $\begin{array}{l}\text { Industr } \\
\mathrm{y}\end{array}$ & Occupation & GC1 & GC2 & GC3 & GC 4 & GC5 & GC6 & GC 7 \\
\hline & & & $\begin{array}{l}\text { organis } \\
\text { ational } \\
\text { policie } \\
\text { s }\end{array}$ & & & & & & \\
\hline $\mathrm{Q}$ & $\begin{array}{l}\text { Human } \\
\text { health } \\
\text { services } \\
\text { Residen } \\
\text { tial care } \\
\text { and } \\
\text { social } \\
\text { work } \\
\text { activitie } \\
\text { s }\end{array}$ & $\begin{array}{l}\text { elderly } \\
\text { home } \\
\text { manager }\end{array}$ & $\begin{array}{l}\text { addres } \\
\mathrm{s} \\
\text { proble } \\
\mathrm{ms} \\
\text { critical } \\
\text { ly }\end{array}$ & $\begin{array}{l}\text { adhere } \\
\text { to } \\
\text { organis } \\
\text { ational } \\
\text { guideli } \\
\text { nes }\end{array}$ & $\begin{array}{l}\text { advoca } \\
\text { te for } \\
\text { others }\end{array}$ & $\begin{array}{l}\text { accept } \\
\text { own } \\
\text { accoun } \\
\text { tability }\end{array}$ & & & \\
\hline $\mathrm{R}$ & $\begin{array}{l}\text { Arts, } \\
\text { entertai } \\
\text { nment } \\
\text { and } \\
\text { recreati } \\
\text { on }\end{array}$ & $\begin{array}{l}\text { recreational } \\
\text { facilities } \\
\text { manager }\end{array}$ & & $\begin{array}{l}\text { establi } \\
\text { sh } \\
\text { daily } \\
\text { prioriti } \\
\text { es }\end{array}$ & $\begin{array}{l}\text { analys } \\
\text { e goal } \\
\text { progre } \\
\text { ss }\end{array}$ & $\begin{array}{l}\text { chair a } \\
\text { meetin } \\
\mathrm{g}\end{array}$ & & & \\
\hline$S$ & $\begin{array}{l}\text { Other } \\
\text { services }\end{array}$ & $\begin{array}{l}\text { quality } \\
\text { services } \\
\text { manager }\end{array}$ & $\begin{array}{l}\text { adhere } \\
\text { to } \\
\text { organis } \\
\text { ational } \\
\text { guideli } \\
\text { nes }\end{array}$ & & $\begin{array}{l}\text { define } \\
\text { quality } \\
\text { standar } \\
\text { ds }\end{array}$ & & & & \\
\hline
\end{tabular}




\subsection{Program code}

File-1: ioScript.R:

Am<-as.matrix(read.csv("data/input_coefficient.csv", header=F, sep=","))

$\operatorname{Im}<$-as.matrix(read.csv("data/import_coefficient.csv", header=F, sep=","))

Y<-as.matrix(read.csv("data/domestic_final_demand.csv", header=F, sep=","))

E<-as.numeric(as.matrix(read.csv("data/exports.csv", header=F, sep=",")))

Lm<-as.matrix(read.csv("data/labour_coefficient.csv", header=F, sep=","))

Om<-as.matrix(read.csv("data/occupation_coefficient_matrix.csv", $\quad$ header=F, sep=","))

$\mathrm{I}<-\operatorname{diag}($ nrow $=19$, ncol $=19)$

\#io <- c(Am, Im, Y, E, Lm, Om, I)

\#names(Am) <- c("A","B","C","D","E","F","G","H","I","J","K", "L", "M", "N", "O", "P", "Q", "R", "S")

\#save(Am, Im, Y, E, Lm, Om, I, file= "io.RData")

$\mathrm{X}<-$ solve $(\mathrm{I}-((\mathrm{I}-\mathrm{Im}) \% * \% \mathrm{Am})) \% * \%(((\mathrm{I}-\mathrm{Im}) \% * \% \mathrm{Y})+\mathrm{E})$

$\mathrm{T} 1<-\mathrm{I}-((\mathrm{I}-\mathrm{Im}) \% * \% \mathrm{Am})$

$\mathrm{T} 2<-(\mathrm{I}-\mathrm{Im}) \% * \% \mathrm{Y}+\mathrm{E}$

$\mathrm{R} 2<-\mathrm{T} 1 \% * \% \mathrm{~T} 2$

$\mathrm{X} 1<-\mathrm{I}-\mathrm{Im}$

File-2: server.R

\# This is the server logic of a Shiny web application. You can run the

\# application by clicking 'Run App' above.

\# Find out more about building applications with Shiny here:

\# http://shiny.rstudio.com/

library(shiny)

library(DT)

load("io.RData")

shinyServer(function(input, output, session) \{

data_list $=\operatorname{list}($ Input $=$ Am, Import $=\mathrm{Im}$, Labour $=\mathrm{Lm}$, Occupation $=$ Om $)$

output\$table_coefficient <- DT::renderDataTable $(\{$

coefficientTable <- data_list[[input\$coefficientTable]]

coefficientTable[as.numeric(input\$selectX), as.numeric(input\$selectY)]<-

input\$coefficient_change

\# X<-solve (I-((I-Im)\%*\%Am))\%*\%(((I-Im)\%*\% $\%)+\mathrm{E})$

\# L<-Lm\%*\%(solve(I-((I-Im)\%*\%Am)))\%*\%(((I-Im)\%*\% $\%)+\mathrm{E})$

\# $\mathrm{O}<-\mathrm{Om} \% * \% \mathrm{X}$

\{coefficientTable

datatable(head(coefficientTable, 20),

options $=\operatorname{list}($ pageLength $=20$, dom $=$ 'tip' $)$, 
colnames

c("A","B","C","D","E","F","G","H","I","J","K","L","M","N","O","P","Q","R","S"),

rownames

c("A","B","C","D","E","F","G","H","I","J","K","L","M","N","O","P","Q","R","S"))

\})

output\$table_domestic <- DT::renderDataTable $(\{$

coefficientTable <- data_list[[input\$coefficientTable]]

coefficientTable[as.numeric(input\$selectX), as.numeric(input\$selectY)]<-

input\$coefficient_change

$\mathrm{X}<-$ solve(I-((I-data_list[['Import']])\%*\%coefficientTable $)) \% * \%(((\mathrm{I}-$

data_list[['Import']])\%*\%Y)+E)

$\mathrm{L}<-\mathrm{Lm} \% * \%($ solve(I-((I-Im) \%*\%coefficientTable $))) \% * \%(((\mathrm{I}-\mathrm{Im}) \% * \% \mathrm{Y})+\mathrm{E})$

$\mathrm{O}<-\mathrm{Om} \% * \% \mathrm{X}$

$\{\mathrm{X}\}$

datatable(head(X, 20),

colnames $=\mathrm{c}($ 'Total Domestic Product'),

options $=$ list $($ pageLength $=20)$,

rownames

c("A","B","C",,D","E","F","G","H","I","J","K","L","M","N","O","P","Q","R","S"))

\})

output\$table_labour <- DT::renderDataTable $(\{$

coefficientTable <- data_list[[input\$coefficientTable]]

coefficientTable[as.numeric(input\$selectX), as.numeric(input\$selectY)] $<-$ input\$coefficient_change

$\mathrm{X}<-$ solve $(\mathrm{I}-((\mathrm{I}-\mathrm{Im}) \% * \%$ coefficientTable $)) \% * \%(((\mathrm{I}-\mathrm{Im}) \% * \% \mathrm{Y})+\mathrm{E})$

$\mathrm{L}<-\mathrm{Lm} \% * \%($ solve(I-((I-Im) \%*\%coefficientTable $))) \% * \%(((\mathrm{I}-\mathrm{Im}) \% * \% \mathrm{Y})+\mathrm{E})$

$\mathrm{O}<-\mathrm{Om} \% * \% \mathrm{X}$

$\{\mathrm{L}\}$

datatable(head(L, 20),

colnames $=\mathrm{c}($ 'Total labour in thousand'),

options $=$ list $($ pageLength $=20)$,

rownames

c("A","B","C","D","E","F","G","H","I","J","K","L","M","N","O","P","Q","R","S"))

\})

output\$table_occupation <- DT::renderDataTable $(\{$

coefficientTable <- data_list[[input\$coefficientTable]]

coefficientTable[as.numeric(input\$selectX), as.numeric(input\$selectY)]<-

input\$coefficient_change

$\mathrm{X}<-$ solve $(\mathrm{I}-((\mathrm{I}-\mathrm{Im}) \% * \%$ coefficientTable $)) \% * \%(((\mathrm{I}-\mathrm{Im}) \% * \% \mathrm{Y})+\mathrm{E})$

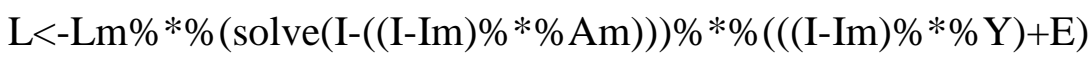

$\mathrm{O}<-\mathrm{Om} \% * \% \mathrm{X}$

$\{\mathrm{O}\}$ 


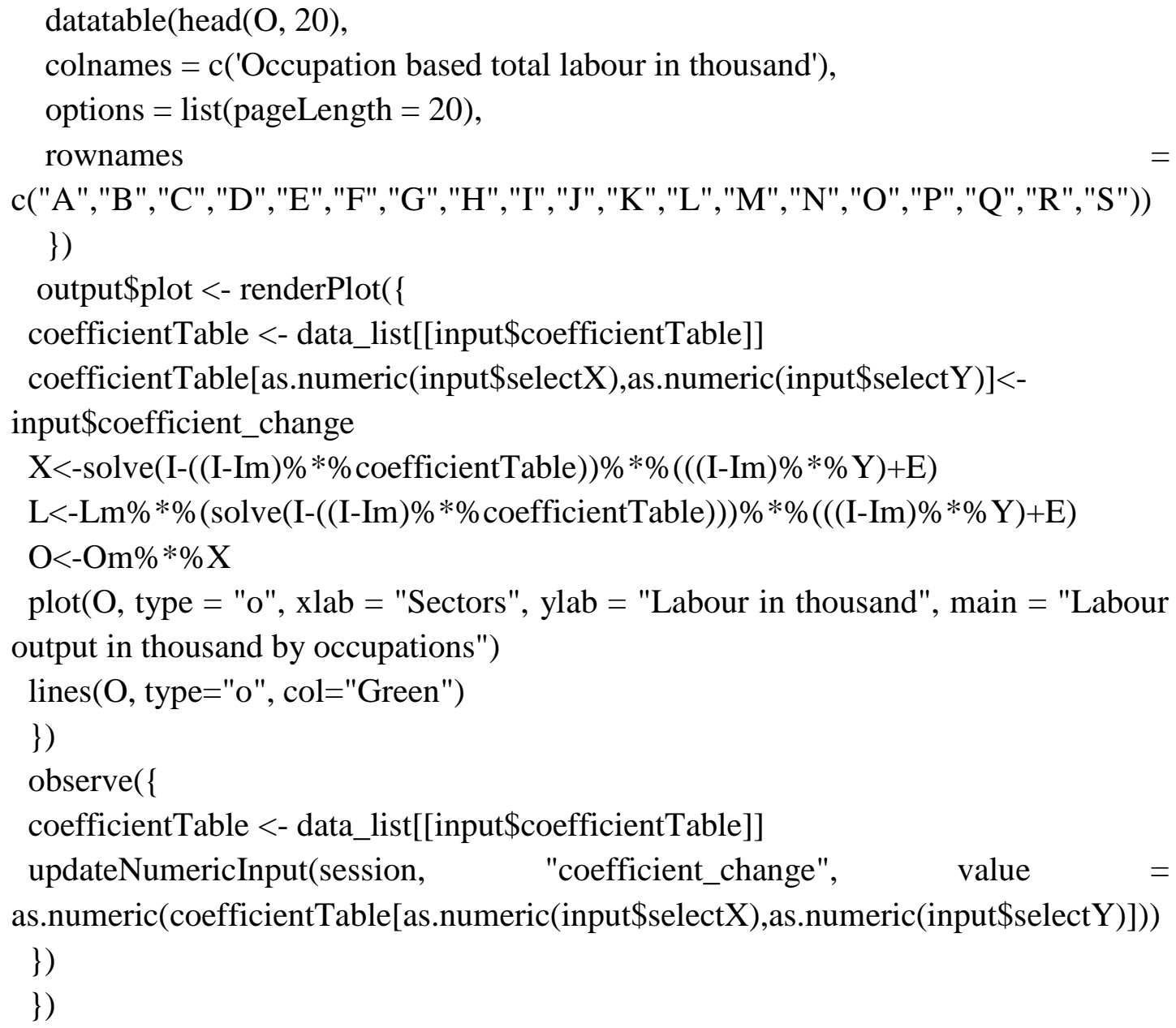


"Manufacturing-C" = 3, "Electricity, gas, steam and airconditioning supply - D" $=4$,

"Water supply, sewerage, waste management and remediation $\mathrm{E}^{\prime \prime}=5$,

"Construction - F" $=6$, "Wholesale and retail trade, repair of motor vehicles and motorcycles $-\mathrm{G}^{\prime \prime}=7$,

"Transportation and storage $-\mathrm{H}^{\prime \prime}=8$, "Accommodation and food service activities - I" $=9$,

"Publishing, audio-visual and broadcasting activities, telecommunications and otherinformation services - $\mathrm{J"}=10$,

"Financial and insurance activities - K"=11, " Real estate activities - L"=12, "Legal, accounting, management, architecture, engineering, technical testing and analysis activities $-\mathrm{M}^{\prime \prime}=13$,

"Administrative and support service activities - N"=14, "Public administration and defence, compulsory social security - $\mathrm{O}^{\prime \prime}=15$,

"Education - P" = 16, "Human health services, Residential care and social work activities - Q" $=17$,

"Arts, entertainment and recreation - R" $=18$, "Other services $S^{\prime \prime}=19$

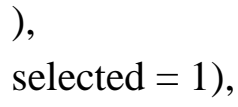
choices = list("Agriculture, forestry and fishing - A" = 1, "Mining and quarrying $-\mathrm{B}^{\prime \prime}=2$,

"Manufacturing-C" = 3, "Electricity, gas, steam and airconditioning supply - D" = 4, $\mathrm{E}=5$,

"Water supply, sewerage, waste management and remediation -

"Construction $-\mathrm{F}^{\prime}=6$, "Wholesale and retail trade, repair of motor vehicles and motorcycles - G" $=7$,

"Transportation and storage $-\mathrm{H}^{\prime}=8$, "Accommodation and food service activities - I" = 9,

"Publishing, audio-visual and broadcasting activities, telecommunications and otherinformation services - $\mathrm{J} "=10$,

"Financial and insurance activities - $\mathrm{K} "=11$, " Real estate activities - L"=12, "Legal, accounting, management, architecture, engineering, technical testing and analysis activities $-\mathrm{M}^{\prime \prime}=13$,

"Administrative and support service activities - N"=14, "Public administration and defence, compulsory social security - $\mathrm{O} "=15$, 
"Education - P" = 16, "Human health services, Residential care and social work activities - Q" $=17$,

"Arts, entertainment and recreation - R" $=18$, "Other services $\mathrm{S}^{\prime \prime}=19$

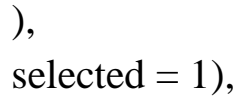

numericInput("coefficient_change", label = h3("Insert new Coefficient Value"), value $=0$ )

)

mainPanel(

tabsetPanel(

tabPanel("Coefficient Values",

fluidPage(DT::dataTableOutput('table_coefficient'))

) ,

tabPanel("Total Domestic Product",

h4("Total domestic product"),

fluidRow( column(4, DT::dataTableOutput('table_domestic'))) ),

tabPanel("Total Labour",

h4("Total thousand labour"),

fluidRow( column(4, DT::dataTableOutput('table_labour')))

) ,

tabPanel("Occupation Based Labour",

h4("Total occupation based thousand labour"),

fluidRow(column(4, DT::dataTableOutput('table_occupation')))

) ,

tabPanel("Plot",

plotOutput("plot")

)

)

)

)) 
